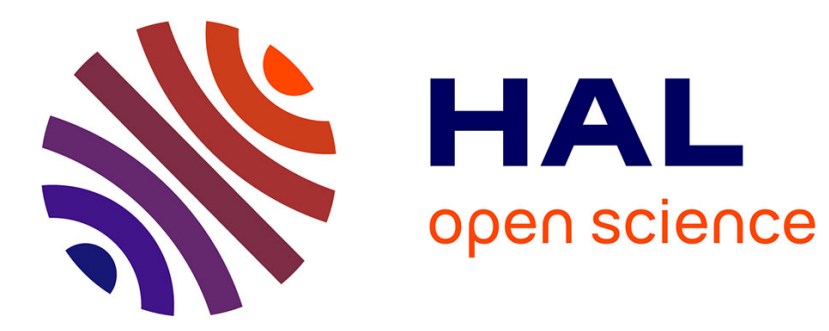

\title{
Have a son, gain a voice: Son preference and female participation in household decision making
}

\author{
Rashid Javed, Mazhar Mughal
}

\section{To cite this version:}

Rashid Javed, Mazhar Mughal. Have a son, gain a voice: Son preference and female participation in household decision making. 2018. hal-01810509

\section{HAL Id: hal-01810509 \\ https://hal.science/hal-01810509}

Preprint submitted on 8 Jun 2018

HAL is a multi-disciplinary open access archive for the deposit and dissemination of scientific research documents, whether they are published or not. The documents may come from teaching and research institutions in France or abroad, or from public or private research centers.
L'archive ouverte pluridisciplinaire HAL, est destinée au dépôt et à la diffusion de documents scientifiques de niveau recherche, publiés ou non, émanant des établissements d'enseignement et de recherche français ou étrangers, des laboratoires publics ou privés. 


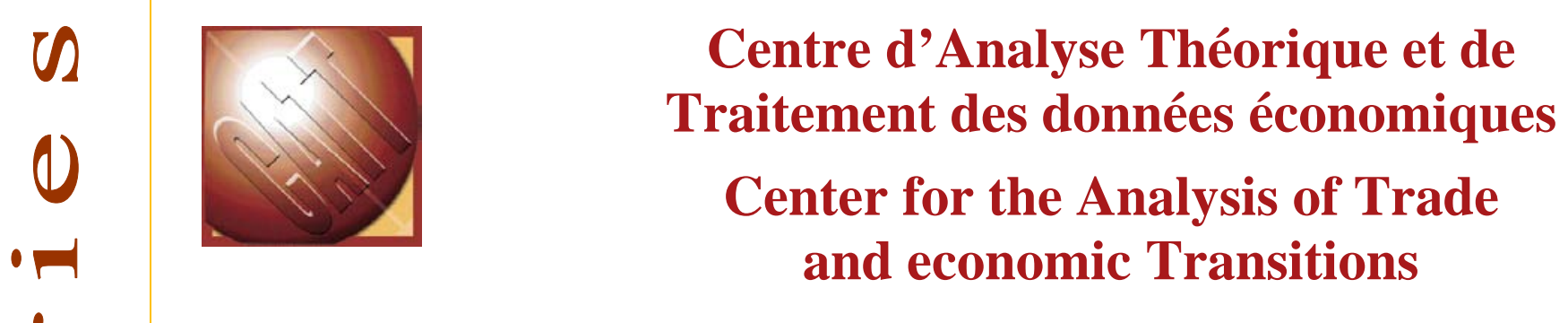

0

CATT WP No. 5

March 2018

HAVE A SON, GAIN A VOICE: SON PREFERENCE AND FEMALE PARTICIPATION IN HOUSEHOLD DECISION MAKING

Rashid JAVED

Mazhar MUGHAL 


\title{
Have a son, gain a voice: Son preference and female participation in household decision making ${ }^{1}$
}

\author{
Rashid Javed \\ PhD candidate, Center for the Analysis of Trade and Economic Transition (CATT), \\ University of Pau and Pays de l'Adour France. \\ E. Mail : muhammad-rashid.javed@univ-pau.fr, rachidjaved@gmail.com \\ [Doctorant, Centre d'Analyse Théorique et de Traitement des données économiques (CATT), \\ Université de Pau et des Pays de L'Adour France]
}

\author{
Mazhar Mughal \\ Associate Professor, Pau Business School, France \\ E-mail: mazhar.mughal@esc-pau.fr \\ [Professeur, École supérieure de commerce de Pau, France]
}

\footnotetext{
${ }^{1}$ Acknowledgements: This study benefited from discussions with the participants of the 2017 International Population Conference, IUSSP, Cape Town, South Africa, 2017 Canadian Economic Association conference, Antigonish, Canada, 2017 French Economic Association conference, Nice, France and the IRMAPE Research Seminar at Pau Business School, 15 June 2017. We are grateful to Lionel de Boisdeffre in drawing the conceptual layout and to Charlotte Fontan Sers for her French translation of the abstract.
} 


\begin{abstract}
:
Son preference is common in many Asian countries. Though a growing body of literature examines the drivers and socioeconomic impacts of phenomenon in case of China and India, work on other Asian countries is scarce. This study uses nationally representative survey of over 13 thousand households from Pakistan (PDHS 2012-13) to analyze the effects of observed preference for sons on women's participation in intra-household decision-making. Four key intra-household decisions are considered: decisions regarding healthcare, family visits, large household purchases and spending husband's income. These correspond to four categories of household decisions, namely healthcare, social, consumption and financial. Probit and Ordered Probit are employed as the main estimation techniques and other determinants of household decision-making are controlled for. Besides, a number of matching routines are employed to account for the possibility of potential selection bias.

We find that women with at least one son have more say in household decisions. Bearing at least one son is associated with 5\%, 7\% and 5\% higher say in decisions involving healthcare, social and consumption matters respectively. Women's role in financial affairs, however, does not differ significantly from women with no sons. Female participation in decisionmaking grows significantly with the number of sons but only up to the third parity. These results are particularly visible among younger, wealthier and educated women, and those who got married earlier. The findings suggest a limited improvement in women's bargaining power at home resulting from the birth of one or more sons. This in part explains higher desire for sons expressed by women compared to men in household surveys.
\end{abstract}

Keywords: Son preference; Gender bias; Sex selection; Female decision-making; intrahousehold bargaining; Pakistan.

JEL codes: D13; J13; C13; C70. 


\section{Résumé :}

La préférence pour les garçons est courante en asie. Alors que beaucoup d'études s’intéressent aux facteurs et aux impacts socioéconomiques de ce phénomène en Chine et en Inde, les travaux sur les autres pays asiatiques sont plus rares. A partir d'une enquête nationale réalisée sur plus de 13000 ménages pakistanais (PDHS 2012-13), cette étude analyse les effets de la préférence pour les garçons sur la participation des femmes aux décisions prises dans le ménage. Quatre décisions importantes du ménage seront prises en compte : celles relatives aux soins de santé, aux visites de famille, sur les achats du ménage et sur l’affectation des dépenses des revenus du mari. Celles-ci représentent quatre catégories des décisions au sain du ménage: les décisions lié à la santé, aux liens sociaux, à la consommation et aux affaires financières. Les méthodes Probit et Probit Ordinal sont utilisées pour les estimations de base et d’autres déterminants liés aux décisions prises dans le ménage seront pris en compte. De plus, méthodes d’appariment sont utilisées pour tenir compte d'éventuels biais de sélection.

Les résultats indiquent que le fait d'avoir au moins un fils a une influence sur les décisions du ménage. Le fait d'avoir au moins un fils est associé à une hausse de 5\%, 7\% et 5\% sur les décisions impliquant respectivement les soins de santé, les relations sociales et la consommation. L’implication des femmes dans les finances du ménage ne varie pourtant pas significativement avec celle des femmes sans fils. La participation des femmes dans les prises de décision augmente avec le nombre de fils mais seulement jusqu’à 3 garçons. Ce résultat entraine une amélioration relative sur le pouvoir de négociation des femmes au sein du ménage suite à la naissance d'un ou plusieurs garçons. Cela explique en partie le désir plus fort des femmes d'avoir des fils par rapport aux hommes, selon les enquêtes ménages.

Mots clés: préférence pour les garçons; biais de genre ; prise de décision de femmes ; Pakistan.

JEL codes: D13; J13; C13; C70. 


\section{Introduction:}

"Mother-in-law wanted a male child, woman poisons daughter, commits suicide after quarrel with in-law (The Express Tribune, November 28th, 2016)"².

Such gruesome incidents are not rare in South Asia. Son preference is an age-old phenomenon widespread in the traditional societies of South and East Asia (D 'souza \& Chen, 1980; Dinitz, Dynes, Clarke, \& Dini1z, 1954; Gu \& Roy, 1995; Guilmoto, 2009; Hammad \& Rajoria, 2013; Park, 1983). This preference manifests itself in such sex-selection methods as differential stopping behavior and sex-selective abortion. Approximately two million girls under the age of five are estimated to be missing every year around the world due to this disproportionate desire for male offspring (Altindag et al., 2015) ${ }^{3}$. Skewed preference for sons results in high population growth rates as women's childbearing is not considered complete until the desire number of sons is achieved. In patrilineal societies, sons are perceived to be the households' economic asset as they take up family businesses, carry the family name and insure the parents' old-age finances (Ben-Porath \& Welch, 1976). Daughters, in contrast, are considered an economic burden for the household: parents must save for their dowry, and they leave home to join their husbands in a virilocal setup. As a result, women who bear sons often enjoy high prestige while those who fail to do so face social stigma and pressure at home leading to domestic violence, divorce or even tragedies such as the one mentioned above.

What then is the role of son preference in determining women's participation in intrahousehold decision-making? While literature on the social, economic and demographic drivers of son preference and sex selection has burgeoned in the past couple of decades, this question has so far attracted little attention. A handful of studies have examined the place of

\footnotetext{
${ }^{2}$ https://tribune.com.pk/story/1246288/familial-pressure-woman-kills-daughter-commitssuicide/

${ }^{3}$ One of the first to point out this issue of 'missing women' in Asia was Amartya Sen who reported a large disparity in female to male ratio in Asia particularly South and West Asia and China compared to North America and Europe (Sen, 1990). He suggested the cause to be the prevalence of sex-selective abortions and high female mortality.
} 
woman and the state of her welfare in relation to preference for boys. A couple of studies look at the nutrition and health outcomes of women bearing sons. ( $\mathrm{Li} \& \mathrm{Wu}, 2011$ ) show that a Chinese woman with a first-born son has a 3.9 percentage points' greater role in household decision-making than a woman with a first-born daughter. Having a first-born son improves the mother's nutrition intakes and reduces her likelihood of being underweight. (Kishore \& Spears, 2014) find that women in urban India whose first child is a son have a greater body mass index (BMI) than women whose first child is a daughter. In another study on India, (Zimmermann, 2012) find little evidence of substantial non-monetary female benefits in India. Having a young son rather than a daughter of the same age leads to a short-term improvement in decision-making power. There is some improvement in the woman's say in decisions involving her health and family visits. However, there is no substantial improvement in her involvement in decisions of daily purchases and spending husband's income. Besides, there is no evidence that the woman enjoys greater freedom to perform more day-to-day activities without having to ask for the permission of other household members.

The aforementioned studies focus on China and India, two son prefering countries where fertility rates have substantially declined, social pressures to keep the family size small are strong and sex-selective abortion has been widespread. The question as to how preferential treatment of sons affects household decisionmaking in a Muslim-majority country where fertility rates are high and sex-selective abortion is not common yet remains unanswered.

This study analyzes the effects of observed preference for sons on women's participation in intra-household decision making in one such country, namely Pakistan ${ }^{4}$. The study contributes to the literature in the following ways:

\footnotetext{
4 "Pakistan's experience diverges most sharply from the template in Figure 1 in the absence of any sustained increases in the SRB - a change that would signal widespread use of sexselective abortion. Is the Pakistani response indicative of the unacceptability of sex-selective abortion or of abortion in general? Given the relatively high rates of abortion, the answer is likely to be the former." Also see (Brekke, 2013) and (Almond, Edlund, \& Milligan, 2013) who suggest Islam as the probable reason for lack of empirical evidence for sex selective abortion among Pakistani immigrants in Norway and Canada respectively.
} 
First, the study attempts at understanding the role preference for male child plays in determining a woman's say in household decisions. Improved say in household decisions is a key aspect of female empowerment ${ }^{5}$.

We find a significant association between the indicators of son preference and women's say in intra-household decisions, reflecting women's improved bargaining power at home. This to certain extent explains the high desirability for sons expressed by women in various demographic surveys. The positive consequence of female empowerment in part appears to arise out of disproportionate preference for the male child. The latter is widely reported to have undesirable affects on daughters' health and education outcomes. The improvement in women's agency seems to come at a cost often paid by the girl child.

Secondly, the study distinguishes between decisions considered in the literature as measures of female empowerment. According to (Basu \& Koolwal, 2005), female participation in household decisions can be separated into two groups of female autonomy measures:

1) The self-indulgent or selfish measures of autonomy (e.g. permission to decide on the woman's healthcare, ability to visit friends and relatives without permission, ability to spend husband's income).

2) Instrumental measures of autonomy as responsibility (e.g. decision to purchase major household items).

(Basu \& Koolwal, 2005) consider decisions of the first category better measures of female empowerment as they allow the woman more freedom to do relatively unproductive things and have more control of their own bodies. Such classifications however ignore the balance of power and the underlying limits to bargaining within the household. A change in situation (e.g. birth of a child) modifies the power equation at home, leading to a new power balance. In our view, the extent to which the husband concedes space to the wife is subject to the nature of the decision. We argue that female empowerment could be understood by simply considering household decisions as either:

\footnotetext{
${ }^{5}$ Empowerment is a process which can be defined as "The expansion in people's ability to make strategic choices in a context where this ability was previously denied to them" (Kabeer, 2000). Its main components are resources, perceptions, relationships and power (Marty, 1992).
} 
1) 'everyday' or 'mundane' which correspond to less important social, healthcare or economic matters not indicative of the existing power balance between the husband and the wife (e.g. visiting friends or relatives, seeing a doctor, buying a household item), or

2) 'strategic' (mainly involving money matters) which reflect real source of power at home (e.g. who decides how much to spend) ${ }^{6}$.

The observation that women are excluded from key household decisions and limited to routine matters is also reported in other development studies. (Jejeebhoy \& Sathar, 2001), for instance report in the context of Indian Subcontinent:

"Women in general have limited economic decisionmaking authority: large numbers are excluded from even the most routine decisions, and few have the major say in any decision. There is a definite pattern to the kinds of decisions in which women participate: they are far more likely to be involved in decisions that are perceived as routine in the family economy, such as those relating to food purchases, than in decisions that involve major purchases." (Page 699). Also see (Zimmermann, 2012) on India.

(Mader \& Schneebaum, 2013) report that across Europe, women are limited to decisions compatible with traditional "women's roles" as mothers and care-takers of family members and the household while husbands remain the primary decisionmakers in household financial matters.

We find that women's say in everyday decisions increases to certain extent as a result of bearing sons. This however does not necessarily reflect a greater bargaining power as her voice in financial matters does not improve. We elaborate this argument in the next section.

Thirdly, the study examines whether or not the role of son preference grows with the number of sons and birth parity. We find evidence of greater say among women having given birth to more than one sons. However, whatever improvement in women's participation in household decisions results from bearing sons dissipates beyond the third birth. This points to improvement in women's say to be context-dependent. Bearing sons beyond the optimal number does not increase the wife's bargaining position.

\footnotetext{
${ }^{6}$ A related concept is that of 'Orchestrated power' (Woolley \& Marshall, 1994).
} 
The rest of the study is organized as follows: The next section presents the conceptual framework. Section 3 briefly describes the son preference and female decision-making situation in Pakistan. Section 4 presents the data and methodology followed by findings and discussion in Section 5. Robustness measures are described in Section 6. The last section concludes and discusses possible implications of the findings.

\section{Conceptual framework:}

Husband: "I make the important decisions. She makes the rest.” (Woolley \& Marshall, 1994).

We consider a modified collective model of household bargaining broadly in line with the arguments of (Mazzocco, 2006) and (Voena, 2015) to develop the study's conceptual framework. Let us take a nuclear household in which the two agents (i.e. husband and wife) enter a limited commitment contract upon getting married. The role of each of the two is accordingly defined in the household and corresponding Pareto weights are assigned. This distribution of power can be renegotiated over time in response to shocks that affect the couple's individual and collective preferences.

Every unblocked decision the couple makes is based on consensus between the husband and the wife. The couple maximizes its utility with respect to household decision as follows:

$$
\begin{aligned}
& \operatorname{Max} U(x) \\
& U\left(x_{1}, \ldots \ldots . x_{k}\right)=\Theta_{H} U_{H}\left(x_{1}, \ldots \ldots . x_{k}\right)+\Theta_{W} U_{W}\left(x_{1}, \ldots \ldots . x_{k}\right) \quad \text { and } \Theta \in[0,1] \\
& \text { Where } \Theta_{H}=1-\Theta_{W}
\end{aligned}
$$

$\mathrm{U}$ is the household utility while $\mathrm{x}$ is the particular decision relating to consumption, social, healthcare or financial matters. $U_{H}$ and $U_{W}$ are the husband's and the wife's utilities respectively, $\Theta_{\mathrm{H}}$ and $\Theta_{\mathrm{W}}$ are the Pareto weights that respectively capture the distribution of power between the husband and the wife. There are a number of factors (such as whether or not the woman bears sons, whether or not she earns money) that act as shocks which could influence her bargaining power in the household. Given the household's preference for boys, the woman enters an implicit agreement at the time of marriage to bear sons. This initial state can be given as:

$$
\mathrm{U}\left(\mathrm{x}_{1}, \ldots \ldots . \mathrm{x}_{\mathrm{k}}\right)=\Theta_{\mathrm{H} 1} \mathrm{U}_{\mathrm{H}}\left(\mathrm{x}_{1}, \ldots . . \mathrm{x}_{\mathrm{k}}\right)+\Theta_{\mathrm{W} 1} \mathrm{U}_{\mathrm{W}}\left(\mathrm{x}_{1}, \ldots . . \mathrm{x}_{\mathrm{k}}\right) \quad \text { and } \Theta \in[0,1](2)
$$


The wife fulfils her contract by giving birth to at least one son ( $>0$ ). The contract is thereby renegotiated giving her an increased Pareto weightage. Her modified bargaining power $\Theta_{\mathrm{W} 2}$ is higher than the power $\Theta_{\mathrm{W} 1}$ that she would have exercised had she borne no son $(\mathrm{S}=0)$.

$$
\mathrm{U}\left(\mathrm{x}_{1}, \ldots \ldots . \mathrm{x}_{\mathrm{k}}\right)=\Theta_{\mathrm{H} 2} \mathrm{U}_{\mathrm{H}}\left(\mathrm{x}_{1}, \ldots \ldots . \mathrm{x}_{\mathrm{k}}\right)+\Theta_{\mathrm{W} 2} \mathrm{U}_{\mathrm{W}}\left(\mathrm{x}_{1}, \ldots \ldots \mathrm{x}_{\mathrm{k}}\right) \quad \text { and } \Theta \in[0,1]
$$

Thus $\Theta_{\mathrm{W} 2}>\Theta_{\mathrm{W} 1}$ if $0<\mathrm{S} \leq \Omega$ where, $\Omega$ is the optimum number of sons.

This favourable equation holds as long the desired number of sons $\Omega$ is not attained, beyond which the utility of bearing sons tapers off and the woman's role in household decision making does not increase any further.

In a patriarchal family setting, the woman's improved say at home does not necessarily exceed that of the husband even if the woman bears sons (i.e. $\Theta_{\mathrm{H} 2}>\Theta_{\mathrm{W} 2}$ ).

We assert that the improvement in female participation in the household decisions varies with the decisions' nature. The wife gains more weight in everyday household decisions (those related to everyday running of the house) while crucial or strategic issues (those pertaining to investments or household finances) stay with the husband. The system can be separated thus:

$$
\begin{aligned}
& \mathrm{U}\left(\mathrm{x}_{1}, \ldots \ldots . \mathrm{x}_{\mathrm{k}}\right)=\sum_{k=1}^{K^{\prime}} \alpha_{\mathrm{k}} \mathrm{U}_{\mathrm{k}}\left(\mathrm{x}_{\mathrm{k}}\right) \quad \text { and } \alpha_{\mathrm{k}}>0 \\
& \mathrm{U}_{\mathrm{k}}\left(\mathrm{x}_{\mathrm{k}}\right)=\mathrm{\Theta}_{\mathrm{H}}{ }^{\mathrm{k}} \mathrm{U}_{\mathrm{H}}{ }^{\mathrm{k}}\left(\mathrm{x}_{\mathrm{k}}\right)+\mathrm{\Theta}_{\mathrm{W}}{ }^{\mathrm{k}} \mathrm{U}_{\mathrm{W}}{ }^{\mathrm{k}}\left(\mathrm{x}_{\mathrm{k}}\right)
\end{aligned}
$$

For everyday decision, $\Theta_{\mathrm{W} 2}>\Theta_{\mathrm{W} 1}$.

In this scenario, female participation in decision making increases as the wife gains more weightage by bearing sons. However, when a strategic decision is being contemplated, then $\Theta_{\mathrm{W} 2}=\Theta_{\mathrm{W} 1}$ and $\Theta_{\mathrm{W} 2}<\Theta_{\mathrm{H} 1}$ and the balance of power stays as before.

In this framework, we assume that children do not have any role in household decision making. With the passage of time and with parents' aging, decision making is gradually transferred to the next generation.

We can extend the model and consider the case of extended household by introducing the role of household elders. Their inclusion further reduces wife's initial role in household decisions and makes her rise in prestige resulting from bearing a son all the more important. 


\section{Son preference and female decision making in Pakistan}

\subsection{Son preference}

Pakistan is the world's sixth most populous country with a population of 207 million according to the 2017 population census (Government of Pakistan, 2017). Among the top ten most populous countries, the country has the third highest overall sex ratio after India (107 males per 100 females) and China (106 males per 100 females) (Figure 1). Pakistan's sex ratio for total population is estimated to be 105 males per 100 females. This ratio is the fourth highest in South Asia after Bhutan (116), India (107), and Afghanistan (106). Pakistan's overall sex ratio has come down steadily over the years from an estimated high of 119 in 1950 (Figure 2). In spite of this sizeable decrease, the country's sex ratio still exceeds the world average by about four percent. In Pakistan, abortion is allowed only in case of threat to mother's life. The country's skewed sex ratio mainly results from differential childbearing patterns (Zaidi \& Morgan, 2016). This can clearly be seen in very high sex ratios at birth (SRB). According to Pakistan Demographic and Health Survey (PDHS) 2012-2013, the country has an SRB of 115 (Table 1). The ratio falls with the parents' education level: households with mothers and fathers having acquired high education have an SRB of 114 and 110 respectively. Sex ratio varies by income: SRB is highest among the middle income groups (118 for the fourth quintile and 117 for the third quintile). The ratio also varies by region and place of residence. Rural areas have a high male to female ratio at birth (117) compared to urban areas (110). The SRB is highest in the most populous province, Punjab (119 male births per 100 female births). The province is Pakistan's bread basket which produces bulk of agricultural produce. The ratio is lowest in the capital city Islamabad (105). The city has the highest literacy rate of all the urban areas in the country.

Please insert Figure $1 \& 2$ here

Please insert Table 1 here 
Another way of looking at the prevalence of son preference is the sex ratio at last birth. The overall sex ratio at last birth is estimated to be 133 males per hundred females. This suggests that childbearing is discontinued only after the birth of a male child. The Parity progression ratio (PPR), that is the proportion of women of a given parity who go on to a higher parity, is accordingly higher among households with no or few sons (Table 2). The parity progression ratio decreases as the number of sons increases, implying that childbearing continues until the desired number of sons (or at least one male child) is achieved. The above sex ratio indicators show a significant incidence of son preference in Pakistan.

This preference is reflected in a substantially low number of girls compared to boys. (Hudson \& Den Boer, 2005) estimated the number of missing girls in Pakistan to be 5.9 million, a figure surpassed only by China and India.

Please insert Table 2 here

\subsection{Female decisionmaking}

In Pakistan, the role of women in household decisions is generally weak. This is reflected in poor ratings on various indicators of women empowerment such as the Gender Inequality Index (GII), Gender Gap Index (GGI), and Social Institutions and Gender Index (SIGI). Among the top ten populous countries, Pakistan has the lowest ranking after India on the Gender Inequality Index (GII) (Figure 3). It is ranked a low 121st on the list. In South Asia, it ranks sixth with only Afghanistan (152nd) and India (130th) behind it.

The OECD Social Institutions and Gender Index (SIGI) which measures the extent of gender discrimination around the world classifies Pakistan as a high gender discrimination country with an index value of 0.301 (Social Institutions and Gender Index 2014). The situation is particularly grim according to the Gender Gap Index (GGI) which ranks Pakistan 143rd out of 144 countries classified (Gender Gap Index 2016). Worse still, the ranking has deteriorated in recent years from 112th place in 2006.

Please insert Figure 3 here 
The Pakistan Demographic and Health Survey (PDHS) 2012-2013 provides direct measures of women's voice in household decisions relating to healthcare, family visits, purchase of big items and spending of husband's income. According to the survey, most intra-household decisions in Pakistan are made either by the husband acting alone or the husband and wife deciding jointly (Table 3). Women overall make only 6-9\% of the household decisions in different aspects by themselves. Their say in household decisions increases with age: $3-4 \%$ of women aged 15 - 24 decide household matters alone while women aged 35 - 49 make 8-12\% of decisions by themselves in different aspects. Likewise, their role in household decisionmaking improves with education: Women without formal education make $5-7 \%$ of household decisions alone. This proportion is 7-8, 8-13 and 9-17\% for women with primary, secondary and higher education respectively for different aspects of decision making. Husband's education also plays some role. Pakistani women coming from urban areas have more say in household decisionmaking (9-14\%) compared with those belonging to rural households (5-6\%). Similarly, women coming from nuclear families (7-10\%) participate more in household decisions compared to those belonging to joint families (3-5\%). Working women too have better decisionmaking power than non-working women. This power steadily increases with household wealth with women in top quintile households making $8-14 \%$ of decisions alone. There is a large regional diversity in women's role in the Pakistani households. Women in the mostly rural, impoverished province of Balochistan could make only $1-2 \%$ of decisions by themselves while women in the capital Islamabad make $8-14 \%$ of household decisions.

Please insert Table 3 here

\section{Data and Methodology}

\subsection{Model and data description}

Our analysis is based on the Pakistan Demographic and Health Survey (PDHS) 2012-13. The 2012-13 PDHS is a representative survey based on interviews with 13,558 households selected using a two-stage stratified sample design. Women in the surveyed households were asked four questions about household decisions. These questions cover four aspects of intrahousehold decisionmaking, i.e. healthcare, social, consumption and financial decisions. 
The corresponding questions are as follows: who usually decides on female respondent's health care? Who usually decides on visits to family or relatives? Who usually decides on large household purchases? and who usually decides what to do with money the husband earns? The first three questions refer to everyday decisions while the fourth corresponds to strategic household decisions. There are five possible responses to each of these polytomous questions: "respondent alone”, “jointly”, "husband/partner alone”, “others” and "family elders”.

In addition to these four indicators, we also consider an aggregate indicator which takes the value of one if the woman has a say in at least one of the four decisions. The five household decision variables are alternately regressed on the son preference indicator while controlling for other individual, household and locational factors that influence women's role in decisionmaking. The presence of at least one son and the number of sons are alternately taken as proxies for son preference. The control factors considered include the respondent woman's age, age difference with the husband, woman's and husband's education level, woman's employment status, family structure ${ }^{7}$, household size, household wealth status ${ }^{8}$, region and area of residence, and exposure to electronic media. The base line model can be given as,

$$
Y_{i j}=\beta_{i}+\gamma_{i}\left(S P_{j}\right)+\sum_{j} \mu_{i j} Z_{j}+\varepsilon_{i j}
$$

Where $Y_{i j}$ represents participation in household decision making $i$ for household $j$, SP stands for son preference, $Z_{j}$ represents the set of household characteristics that can affect decision making behaviour and $\varepsilon_{i j}$ is the error term.

\footnotetext{
${ }^{7}$ A household whose head is neither the woman nor her husband is considered an extended household and nuclear otherwise.

${ }^{8}$ The household wealth variable is generated by constructing a principal component analysis index of household assets such as home ownership, floor type, water source, electricity availability, durable consumer goods etc. The quintiles of the generated variable indicate the economic status of the household.
} 
Please insert Table 4 here

Table 4 describes the variables included in the study. $13 \%$ of the female respondents in the dataset report being without a son while $29 \%$ have one son, $26 \%$ have two sons, $16 \%$ have three sons and $14 \%$ respondents report having given birth to more than three sons. Over half of the female respondents (58\%) possess no formal education compared to $34 \%$ of the husbands. Similarly, only 8\% women report having acquired tertiary level education compared to $16 \%$ husbands. About two thirds of the households (64\%) live in rural areas, while $71 \%$ are nuclear families.

\subsection{Methodology}

The empirical analysis proceeds as follows: In the first step, the overall association between son preference and female household decisionmaking is studied for the four Intrahousehold decisions as well as the aggregate decision indicator by employing the aforementioned indicators of son preference. In the second step, the analysis is performed with reference to birth parity by dividing the households into two groups: households with up to three children and households with more than three children. Close to half the households in the dataset (49\%) have three or fewer children. Dividing the sample into two roughly equal halves lets us observe the differential behavior of small and large households without suffering from the issues related with small sample sizes. We alternatively divide the households based on parity 4. (Results given in Table A1 in the appendix).

Estimations in both steps are carried out by employing a binary variable pertaining to the household decision under study. The variable takes the value of one if the decision is made alone by the female respondent or jointly with the husband, and zero otherwise. Alternatively, another definition of participation in decision making is considered by constructing a categorical indicator for the four types of decisions. The variable takes the values of 1,2 or 3 in the ascending order of women's participation in the decisionmaking process.

The dataset is restricted to women who are currently married, reside with their husbands, and have at least one child. Appropriate weights are used to ensure the representativeness of the sample. Baseline estimations are carried out using Probit model while those of the alternative 
definition of dependent variables are done using Ordered Probit. Additionally, three matching techniques, namely Propensity Score Matching (PSM), Inverse Probability Weighting (IPW) and Augmented Inverse Probability Weighting (AIPW) are employed to account for the possibility that households with sons may differ from those without in ways that could be considered non random. Average Treatment Effects (ATE) and Average Treatment Effects on the Treated (ATT) are obtained. After the PSM estimations, balancing of the treatment groups and sensitivity are checked. Finally, a panoply of robustness measures are carried out by estimating alternative specifications and sub-samples.

Please insert Table 5 \& 6 here

\section{Results}

Tables 5 and 6 report estimations for the three indicators of son preference, namely the presence of at least one son and number of sons. The association between female decisionmaking and son preference is found to be statistically significant for three out of four types of intrahousehold decisions. Women with at least one son have more say in everyday household decisions involving their healthcare, social and economic affairs (Table 5 Columns 1 - 3). The marginal effects for son preference indicators reported at the bottom of the table show that having given birth to at least one son is associated with $5.2 \%, 7.08 \%$ and $5.73 \%$ higher say in these decisions respectively. Women's role in financial matters, however, does not differ significantly from women with no sons (Column 4).

Overall, women with at least one male child have $6.4 \%$ more say in at least one out of four types of household decisions (Column 5).

This improvement is visible in households with one, two, three or more than three sons alike (Table 6). For instance, women with one, two, three or more than three sons have a $4.8 \%$, $5.4 \%, 6.2 \%$ and $5 \%$ greater marginal probability to decide on their health matters by themselves or in conjunction with their husbands respectively. The corresponding probabilities for social matters are 5.6\%, 8.6\%, 8\% and 9.2\% respectively. As before, the say in financial matters remains insignificant implying that women's participation in decisions deemed strategic does not improve regardless of the number of sons borne. These findings 
help us see son preference's influence on female agency in a historic context as the impact on agency corresponds not only to the latest birth but also to the children previously born.

Please insert Table $7 \& 8$ here

Having given birth to a son among the first three children is associated with greater say in non-financial household decisions for the woman (Table 7). The overall effect is likewise positive with a $6.4 \%$ higher say in one of the four decision categories for the woman with one or more sons among the first three children borne. The effect is insignificant among large households (those with four or more children). The results of parity 4 (shown in the appendix) are also similar.

Likewise, the sex of last child does not influence women's participation rates (Table 8).

The parity-wise estimations reported in Table 7 depict another feature of the son preference agency relationship. While having borne one or more sons is positively related to female participation in intrahousehold decisions upto the third parity, the relationship loses its significance in high-parity households. In other words, what matters is not merely the number of sons but crucially, their parity. Sons therefore represent a normal good whose utility loses its significance in large households.

The aforementioned findings reflect the fact that a society with high preference for boys allows son-bearing women better say in household decisions. This is particularly true for women who married young, i.e. those who married before the age of 18 (Table 9). Early marriages are not uncommon in Pakistan. 43\% women in the sample got married before their $18^{\text {th }}$ birthday. Women who marry later do not see a significant improvement in their participation in household decisions as a result of giving birth to sons.

Please insert Table 9 here

The control variables included in the estimations are often significantly associated with female intrahousehold decisionmaking with mostly expected signs. Women's say in household decisions increases with women's age as well as age difference with the husbands. In Pakistan, married women are at an average 5.3 years younger than their husbands. Moreover, educated women and working women seem to participate more in household 
decisions. Women living in nuclear households and urban areas similarly have more say in household decisions. In rural areas, joint family settings are widespread. In such a setup, power often lies in the hands of the family elder who could either be the male or female head of the household. Exposure to media is another factor positively associated with female decisionmaking power. Women who watch the television more frequently are better aware of their rights and more informed about urban and global trends.

\section{Sensitivity and robustness measures}

\subsection{Alternative measures for participation in decision making}

The results described above could be an artifact of the particular construction of the indicators of female participation in decision making. To account for this possibility, we consider an alternative set of dependent variables. The binary indicator of participation in household decisions that stands for the wife making the decision by herself or in conjunction with her husband as opposed to she reporting to have no say in the decision is substituted by a categorical indicator reflecting a supposedly increasing order of woman's participation in the decision. Corresponding estimations using Ordered Probit shown in Tables 10 to 12 report findings largely similar to the baseline estimations shown above. These estimations provide a further insight into the intrahousehold bargaining that happens as a result of male childbearing. For instance, a woman with at least one son is found to have $2.2 \%$ higher likelihood of deciding about her health by herself and 3.3\% higher likelihood of deciding jointly with her husband, while the likelihood that her husband or family elder would decide alone falls by $2.7 \%$ and $2.8 \%$ respectively. The increase in power to decide for herself is the highest for healthcare decisions. Financial decisions, as before, remain out of the woman's reach.

Please insert Table 10, 11 \& 12 here

\subsection{Role of sex-selective abortion}

The questions related to our dependent variable gauged women's participation in various household decisions at the time of the survey which (barring the possible exception of the last 
birth) follows the woman's existing reproductive history. This precludes a direct effect on the sex of children already born. If however the woman's agency could be treated as identical to the one present at the time of previous births, its influence over the sex of children could manifest itself through sex-selective abortions as a son preferring woman with greater decisionmaking power would be more likely to abort female foetus. An alternative would be to accept higher fertility in order to ensure the desired number of sons. In both the cases, the woman may be at greater risk of pregnancy losses. The latter could prove helpful in the absence of data on abortion in our dataset.

Table 13 shows estimations on a subsample of women with at least one pregnancy loss. The results corroborate the findings of the complete sample. The impact of bearing at least one son on the three non-financial decisions stays significant with strong coefficients while that on financial decisions remains insignificant.

Please insert Table 13 here

\subsection{Selection by wealth, woman's education and age and family size}

An important challenge to our empirical analysis comes from selection bias. We consider four possible scenario:

First, as mentioned by (Rossi \& Rouanet, 2015), if mothers exhibiting specific gender preferences are more likely to die, surviving women would be selected which would underestimate the role of son preference. This bias could be handled by focusing on the subsample of younger women. A second way in which the effects of son preference could be biased is through education. Educated women can better understand their situation at home and identify possible options for improving their say. This may also involve sex discriminatory practices. We consider this bias by limiting the sample to women having attained some schooling. Less than half of the women surveyed (42\%) possessed some schooling.

Another way in which son preferring women could be selected is through wealth. Women from wealthier households possess more financial means to ensure the desired number of sons whether through differential stopping or by undertaking sex-selective abortion. We 
account for this possibility by estimating the model on the subsample of households with above median wealth. Finally, the sex of children already borne could influence the decision to have more children. Thus son preferring women may be selected based on the number of children to which they have already given birth. We can check for this bias by focusing on women having given birth to one child as sex selective abortion should not be a worry for the first birth.

Table 14 shows results of estimations carried out on the subsample of young women (25 years and less) and those with some schooling while Table 15 shows results of estimations on wealthy women and those with a single child. The results are qualitatively similar to the main findings. As expected, the impact of son preference gets stronger when we focus on younger, educated and wealthier women. The effect of the sex of firstborn boy on decisionmaking is different in the sense that participation in even financial affairs is found to be significant.

Please insert Table 14 \& 15 here

\subsection{Matching estimations}

To further ease concerns about potential endogeneity, we carry out estimations on our model using three matching routines: Propensity Score Matching (PSM), Inverse Probability Weighting (IPW) and Augmented Inverse Probability Weighting (AIPW). Matching estimators are based on the Rubin Causal Model with two key assumptions of unconfoundedness and overlap (P R Rosenbaum \& Rubin, 1983).

PSM matches treated to non treated based on a propensity score for participation given the observable characteristics of the individual. The IPW improves on the PSM by according a higher weight to individuals receiving an unlikely treatment. This reweighting helps assign higher weights to individuals lying in the middle of the probability distribution and lower weights to those at the extremes (Wooldridge, 2007). The third technique AIPW combines both the properties of the regression based estimator and the IPW estimator, requiring either the propensity or outcome model (not both) to be correctly specified (Cao, Tsiatis, \& Davidian, 2009). 
Both the average treatment effect (ATE) and the average treatment effect on the treated (ATT) are obtained. ATE is the difference between the expected outcomes with and without treatment while ATT is the difference between expected outcome values with and without treatment for those who actually participated in treatment.

Results for PSM estimations given in Tables 16 and 17 show a picture similar to our probit and ordered probit estimations ${ }^{9}$. In the case of women with one or more sons, The ATT for participation in healthcare, social and consumption-related decisions is significant at least at the $10 \%$ level. The ATT for women with at least one son compared to women without a son is $6.4 \%, 7.3 \%$ and $5.3 \%$ for decisions pertaining to respondent's healthcare, social and consumption decisions respectively. These average effects are in line with the effects found with Probit estimations, and are even somewhat stronger. The impact on financial decisions is insignificant as before. The result for the aggregate decision indicator is likewise significant with an average effect of 6.3\% (Column 5).

Please insert Table 16 \& 17 here

We also carry out parity-wise matching estimations: two sets of households are considered with groups of women upto three children (parity $<=3$ ) and those having more than three children (parity > 3) alternatively taken as treatment groups. As found previously, son preference is found to have a significant effect on female participation in non-financial decisions for upto the third parity beyond which no significant effect could be traced (Table 17). If anything, the negative signs of ATT for parity above three points to a decreasing female participation in household decisions (Columns 6 - 10).

Table 18 shows IPW and AIPW estimates. Results of both the estimators are qualitatively similar to previous findings. For instance, the ATT for the aggregate decisions for both the techniques is found to be $6 \%$ as compared to $6.3 \%$ for PSM and $6.4 \%$ marginal effect for the baseline probit estimation. Having one or more sons leads to $6 \%$ higher participation in at least one out of four types of household decisions compared with women without a son.

\footnotetext{
${ }^{9}$ Estimations are carried out using Stata user command psmatch2 developed by (Leuven \& Sianesi, 2003).
} 
The close similarity of our matching estimates with the baseline probit estimates makes us reasonably confident of the sign and significance of our estimation results.

Please insert Table 18 here

We graphically assess common support for treatment and control groups used in PSM estimations (Figure 4). Graphs for the five decision estimations are similar and show satisfactory overlapping scores for households with no and at least one son.

We explore the balancing properties of covariates across the treatment and control groups ${ }^{10}$. The results of propensity balance check presented in table 19 show that the standardised mean difference for the treated and untreated covariates is small. Standardised difference for most of the covariates are round or less than $10 \%$, indicating adequate balancing.

Please insert Figure 04 here

Please insert Table 19 here

Finally, we check the robustness of our matching estimates to selection on unobservables by performing the Rosenbaum bounds test (Paul R Rosenbaum, 2002) ${ }^{11}$. Table 20 reports the minimum and maximum values for the Mantel-Haenszel bounds along with their significance levels for participation in healthcare decisions. Results for this and other decision estimations are significant at $10 \%$ or less except for the financial affairs estimation. For healthcare decisions, the results lose their significance at $10 \%$ at and beyond a $\Gamma$ value of 1.2 . The corresponding value of $\Gamma$ for social and consumption decisions is 1.35 while that for all decisions is 1.1. $\Gamma$ for financial matters is initially insignificant but turns significant for $\Gamma$ at and above 1.2. These low values of $\Gamma$, however, are not atypical in social sciences.

\footnotetext{
${ }^{10}$ We use Stata's pbalchk user command (Lunt, 2007) for this purpose.

${ }^{11}$ We use the Stata user command mhbounds (Becker \& Caliendo, 2007) for this purpose.
} 


\subsection{Role of woman's health}

Another possibility is that a woman's health may determine the extent of her say at home with weak or unhealthy women being able to participate less in intra-household decisions. We take into account this possible influence of a woman's unhealthiness by estimating the model on a subsample of women with unhealthy body mass index (below 18.5 or above 25). The son preference - decisionmaking relationship given in table 21 is found to have similar levels of significance as before.

Please insert Table 21 here

\subsection{Alternative controls}

A woman's status at home may vary depending upon the number of children she bears. We control for this possibility by including the number of children in the model. Similarly, the indicator of wealth in the DHS dataset is an asset-based composite index which may not accurately capture a household's wealth. We substitute this index by a strong indicator of household wealth, namely ownership of a car.

Results of these two estimations shown in tables 22 and 23 do not vary significantly from those of the baseline model. A woman's participation in household decisions increases in the number of children she bears and does not vary by wealth.

Please insert Tables 22 \& 23 here

We also check whether the non linearity of age affects the son preference - decisionmaking relationship by introducing a quadratic term in the model. The squared age variable is mostly 
found to be insignificant and does not alter the relationship in question (Results given in Table A2 in the appendix).

\subsection{Other measures of female agency}

Finally, we estimate the association between preference for male child and objective measures of women's empowerment. Table 24 shows estimations with woman's Body Mass Index (BMI) and her employment status as dependent variables.

Son preference has a positive relationship with a woman's employment status. The effect on her BMI is interesting: while the likelihood of a woman being underweight (BMI less than 18.5) or of normal weight (BMI between 18.5 and 24.9) is lower among women with at least one son, opposite is true for the likelihood of being overweight (BMI between 25 and 29.9) and obese (BMI above 30). In Pakistan, women's weight is often a reflection of her socioeconomic status ${ }^{12}$.

These findings provide tentative support to the argument that women with sons enjoy improvements in her domestic life.

Please insert Table 24 here

\subsection{Placebo tests}

Given the non-experimental cross-sectional nature of our survey data and the fact that the outcomes and covariates of interest are demographic indicators, devising suitable placebo tests is challenging. We alternately replace the decisionmaking outcome variables by a couple of variables which should plausibly not be related to our covariate of interest:

First, consanguineous marriages are widespread throughout the country. The fact the couple is related should not depend on whether it later on has one or more sons. Table 25 shows the

\footnotetext{
${ }^{12}$ For instance, women with above median wealth in PDHS have a BMI of 29.1 compared with 24.3 for women with below median wealth.
} 
estimation using the incidence of consanguineous marriage as outcome. The association with the son preference variable expectedly appears to be highly insignificant ( $\mathrm{P}$-value $=0.85$ ). Subsequent columns respectively show sets of estimations on the subsample of related couples and those who do not declare themselves to be related. The two sets of results are highly similar and corroborate the baseline findings.

Please insert Tables 25 \& 26 here

Second, we can reasonably argue that whether or not the husband works does not depend on whether or not he has a son. Third, we employ a seemingly absurd outcome variable: whether the survey team visited the house once or more. Both these variables should in principle be independent of whether or not the woman has a son.

As expected, the results of these estimations given in table 26 are invariably insignificant.

\subsection{Testing multiple hypotheses}

We carry out Multivariate analysis of variance and covariance (MANOVA) tests using our five decision variables and the binary son preference variable. Results of the four statistics (Wilks’ lambda, Pillai's trace, Lawley-Hotelling trace, and Roy’s largest roo) given in table 27 all show that the null hypothesis of equality of means is rejected at the $1 \%$ level of significance.

Please insert Table 27 here

We also employ Bonferroni correction for testing the statistical significance of the regression coefficients of our covariates of interest. The method corrects for the P values when multiple tests are simultaneously performed on the same data. Table 28 Shows Bonferroni corrections for ten pair-wise comparisons taking the health decision estimation as the first. We find that eight out of ten pairs are significantly different at the $5 \%$ level or better according to the $\mathrm{P}$ values shown and nine out of ten pairs according to the t statistics.

Please insert Table 28 here 


\section{Concluding remarks}

(Duvendack \& Palmer-Jones, 2017) write:

"The association of women's agency with human development is a shibboleth of recent development studies and for many the nearest thing there is currently to a magic bullet for human development”

Our analysis shows that a cause of improvement in female decisionmaking may well be the disproportionate preference for male child which in itself symbolizes perpetuation of discriminatory social status for women. This sheds a less glorious light on female participation in household decision making as seen from the perspective of women's empowerment. This, to a certain extent, explains the reason why women in the Indian Subcontinent show stronger preference for boys than do their husbands ${ }^{13}$.

The finding also puts into question the adequacy of the commonly used variables of women's participation in household decision making as indicators of female empowerment.

We show that even the reported improvement in female participation in household decisions resulting from bearing sons is context-specific and depends on the nature of decisions being taken, parity and age at marriage. Compared to women with no sons, women having given birth to at least one son exercise more power in everyday decisions (those pertaining to healthcare, family visits and major household purchase items). For instance, let us consider two sets of households with similar characteristics, one with no son and the other with one son. In the first type of household, women have a $45 \%$ probability of making a decision on major household purchases either by themselves or in conjunction with their husbands. In contrast, the corresponding probability for households with one son is $50 \%$.

\footnotetext{
${ }^{13}$ For instance, the desired son to daughter ratio among Pakistani women is 108 compared to 106 among men (PDHS 2012-13).
} 
The beneficial effect can be seen in households with one, two or three sons. The effect loses its potency beyond the third parity. From this reference point, sons are a normal good whose production improves the producer’s bargaining power but with diminishing utility.

Besides, the balance of power does not change in decisions deemed strategic as bearing one or more sons does not lead to better participation in financial matters. Women's say in how to spend husband's income does not vary with the number of sons. This implies that husbands concede space to son-bearing wives only in non financial matters perceived to be of lesser importance. The gain in women's voice resulting from change in situation at home thus remains limited and context-specific.

\section{References}

Almond, D., Edlund, L., \& Milligan, K. (2013). Son Preference and the Persistence of Culture: Evidence from South and East Asian Immigrants to Canada. Population and Development Review, 39(1), 75-95. https://doi.org/10.1111/j.1728-4457.2013.00574.x

Altindag, O., Joyce, T., Vijverberg, W., Grossman, M., Jaeger, D., \& Dinçer Seminar, A. (2015). CUNY Academic Works Son Preference, Fertility Decline and Non-Missing Girls of Turkey Son Preference, Fertility Decline and the Non-Missing Girls of Turkey. City University of New York (CUNY). Retrieved from http://academicworks.cuny.edu/gc_econ_wp

Arnold, F., Choe, K., \& Roy, T. K. (1998). Population Investigation Committee Son Preference, the Family-Building Process and Child Mortality in India Son preference, the family-building process and child mortality in India. Source: Population Studies UTC Population Studies, 5234(52), 301-31546. Retrieved from http://www.jstor.org/stable/2584732

Basu, A. M., \& Koolwal, G. B. (2005). Two Concepts of Female Empowerment : Some Leads From Dhs Data on Women' S Status. ORC Macro Calverton, Maryland, USA. Retrieved from http://pdf.usaid.gov/pdf_docs/pnade016.pdf\#page=22

Becker, S. O., \& Caliendo, M. (2007). Mhbounds-sensitivity analysis for average treatment effects. The stata journal. Retrieved from http://papers.ssrn.com/sol3/papers.cfm?abstract_id=958699 
Ben-Porath, Y., \& Welch, F. (1976). Do Sex Preferences Really Matter? Source: The Quarterly Journal of Economics, 90(2), 285-307. Retrieved from http://www.jstor.org/stable/1884631

Brekke, T. (2013). Religion and sex-selective abortion: a comparative study of immigrants from South Asia to Norway. Diaspora Studies, 6(1), 31-39. https://doi.org/10.1080/09739572.2013.843290

Cao, W., Tsiatis, A. A., \& Davidian, M. (2009). Improving efficiency and robustness of the doubly robust estimator for a population mean with incomplete data. Biometrika, 96(3), 723-734. https://doi.org/10.1093/biomet/asp033

Chung, W., \& Das Gupta, M. (2007). The Decline of Son Preference in South Korea: The Roles of Development and Public Policy. Source: Population and Development Review, 33(4), 757-783. Retrieved from http://www.jstor.org/stable/25487621

D ’souza, S., \& Chen, L. C. (1980). Sex Differentials in Mortality in Rural Bangladesh. Source: Population and Development Review, 6(2), 257-270. https://doi.org/10.2307/1972730

Dinitz, S., Dynes, R. R., Clarke, A. C., \& Dini1z, S. (1954). Preferences for Male or Female Children: Traditional or Affectional? Source: Marriage and Family Living, 16(2), 128130. Retrieved from http://www.jstor.org/stable/347767

Duvendack, M., \& Palmer-Jones, R. (2017). Micro-Finance, Women’s Empowerment and Fertility Decline in Bangladesh: How Important Was Women’s Agency? The Journal of Development Studies, 53(5), 664-683. https://doi.org/10.1080/00220388.2016.1205731

Government of Pakistan. (2017). Census division, Federal Bureau of Statistics.

Gu, B., \& Roy, K. (1995). Sex ratio at birth in China with reference to other areas in East Asia: what we know. Asia-Pacific Population Journal, 10(3), 17-42. Retrieved from http://www.popline.org.sci-hub.cc/node/294234

Guilmoto, C. Z. (2009). The Sex Ratio Transition in Asia. Guilmoto Source: Population and Development Review, 35(3), 519-549. Retrieved from http://www.jstor.org/stable/25593663

Hammad, B., \& Rajoria, S. (2013). www.euacademic.org Economics and Sociology of Son 
Preference in India, 1(7), 2286-4822.

Hudson, V. M., \& Den Boer, A. M. (2005). Missing Women and Bare Branches: Gender Balance and Conflict. Retrieved from http://kar.kent.ac.uk/11409/

Jejeebhoy, S. J., \& Sathar, Z. A. (2001). 2001_women empowernment Pakistan India.pdf.

Kabeer, N. (2000). Resources, Agency, Achievements: $\mathrm{Re}^{-}$ections on the Measurement of Women â€ $€^{\mathrm{TM}}$ s Empowerment. Development and Change, 30(May 1999), 435-464. https://doi.org/10.1111/1467-7660.00125

Kishore, A., \& Spears, D. (2014). Having a Son Promotes Clean Cooking Fuel Use in Urban India: Women's Status and Son Preference. Economic Development and Cultural Change, 62(4), 673-699. https://doi.org/10.1086/676330

Leuven, E., \& Sianesi, B. (2003). PSMATCH2: Stata module to perform full Mahalanobis and propensity score matching, common support graphing, and covariate imbalance testing. Statistical Software Components. Retrieved from http://ideas.repec.org/c/boc/bocode/s432001.html

Li, L., \& Wu, X. (2011). Gender of Children, Bargaining Power, and Intrahousehold Resource Allocation in China. Journal of Human Resources, 46(2), 295-316. https://doi.org/10.3368/jhr.46.2.295

Lunt, M. (2007). PBALCHK: stata module to check covariate balance after matching, weighting or stratifying.

Mader, K., \& Schneebaum, A. (2013). The gendered nature of intra-household decision making in and across Europe (No. Department of Economics Working Paper Series, 157.). Vienna. Retrieved from http://epub.wu.ac.at/3995/

Marty, C. (1992). Conceptual Model for Women's Empowerment.

Mazzocco, M. (2006). Household intertemporal behavior : a collective characterization and empirical tests. Review of Economic Studies, 74(3), 857-895. https://doi.org/10.1111/j.1467-937X.2007.00447.x

Park, C. Bin. (1983). Preference for Sons, Family Size, and Sex Ratio: An Empirical Study in Korea. Source: Demography, 20(3), 333-352. Retrieved from 
http://www.jstor.org/stable/2061246

Rosenbaum, P. R. (2002). New York: Springer. Observational Studies.

Rosenbaum, P. R., \& Rubin, D. B. (1983). The central role of the propensity score in observational studies for causal effects. Biometrika, 70(1), 41-55. https://doi.org/10.1093/biomet/70.1.41

Rossi, P., \& Rouanet, L. (2015). Gender Preferences in Africa: A Comparative Analysis of Fertility Choices. World Development. https://doi.org/10.1016/j.worlddev.2015.03.010

Sen, A. (1990). More Than 100 Million Women Are Missing. New York Review Of Books, 37(20), 61-66. Retrieved from http://ucatlas.ucsc.edu/gender/Sen100M.html

Voena, B. A. (2015). Yours , Mine, and Ours: Do Divorce Laws Affect the Intertemporal Behavior of Married Couples? †, 105(8), 2295-2332. https://doi.org/10.2139/ssrn.2007575

Wooldridge, J. M. (2007). Inverse probability weighted estimation for general missing data problems. Journal of Econometrics, 141(2), 1281-1301. https://doi.org/10.1016/j.jeconom.2007.02.002

Woolley, F. R., \& Marshall, J. (1994). Measuring Inequality Within the Household. Review of Income and Wealth, 40(4), 415-431. https://doi.org/10.1111/j.14754991.1994.tb00084.x

Zaidi, B., \& Morgan, S. P. (2016). In the Pursuit of Sons: Additional Births or Sex-Selective Abortion in Pakistan? Population and Development Review, 42(4), 693-710. https://doi.org/10.1111/padr.12002

Zimmermann, L. (2012). It's a boy! Women and non-monetary benefits from a son in India (No. IZA Discussion Paper No. 6847). Retrieved from http://ftp.iza.org/dp6847.pdf 


\section{Figures and tables:}

Figure 1: Overall sex ratio of top ten populous countries

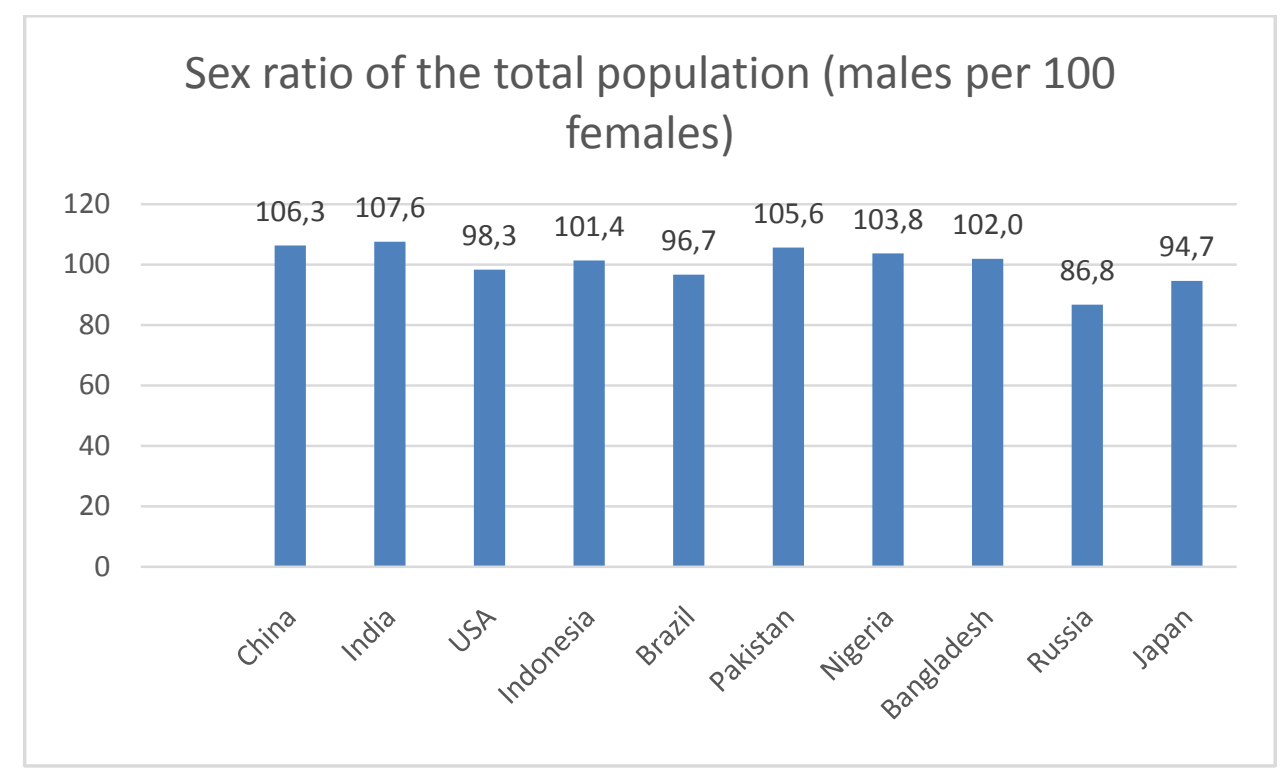

Source: United Nations, Department of Economic and Social Affairs, Population Division (2015). World Population Prospects: The 2015 Revision, DVD Edition. 
Figure 2: Pakistan's overall sex ratio (1950 - 2015)

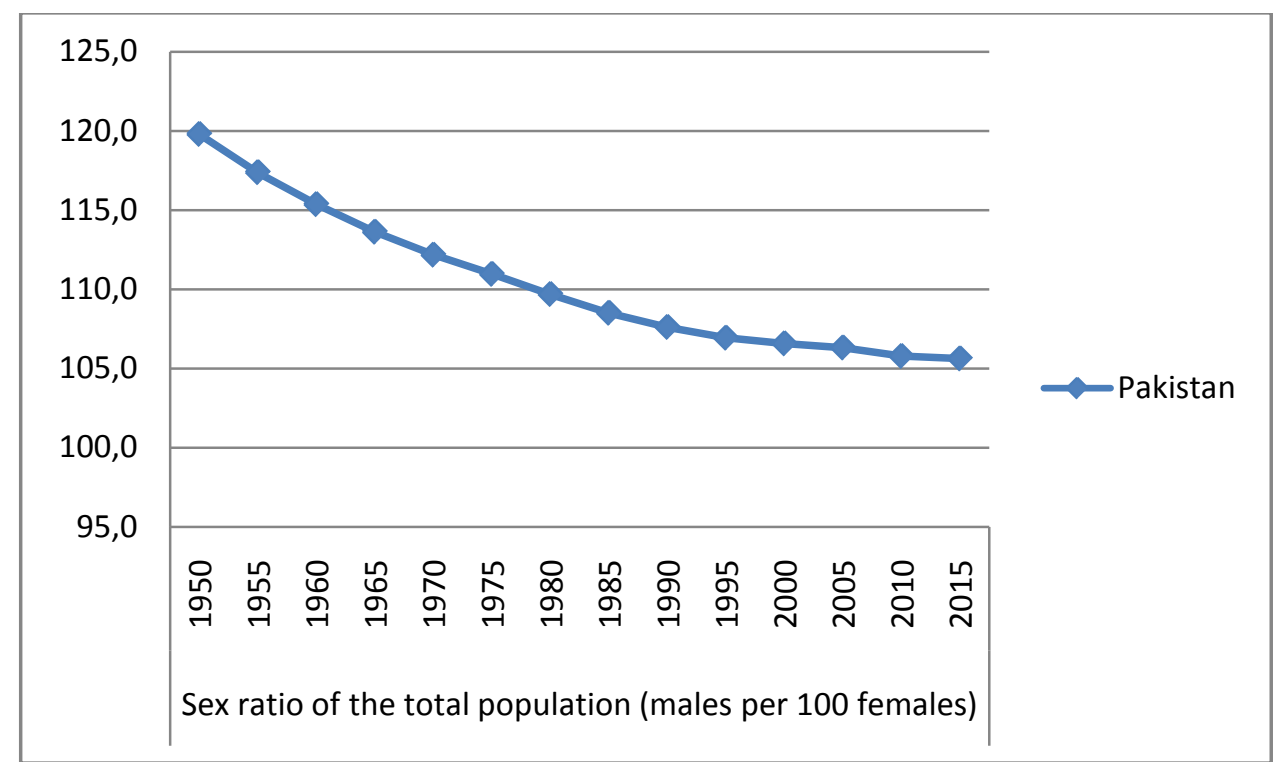

Source: United Nations, Department of Economic and Social Affairs, Population Division (2015). World Population Prospects: The 2015 Revision, DVD Edition. 
Table 1: Sex ratio at birth

\begin{tabular}{|c|c|c|c|c|}
\hline & & Total Sons & Total Daughters & Sex Ratio \\
\hline Overall & & 17560 & 15233 & 115.28 \\
\hline \multirow[t]{6}{*}{ Region } & Punjab & 10414 & 8720 & 119.43 \\
\hline & Sindh & 3738 & 3464 & 107.91 \\
\hline & KPK & 2607 & 2328 & 111.98 \\
\hline & Balochistan & 591 & 521 & 113.44 \\
\hline & Gilgit Baltistan & 145 & 128 & 113.28 \\
\hline & Islamabad & 74 & 70 & 105.71 \\
\hline \multirow[t]{2}{*}{ Place of Residence } & Urban & 5519 & 4981 & 110.80 \\
\hline & Rural & 12051 & 10251 & 117.56 \\
\hline \multirow{4}{*}{ Level of Education } & No Education & 12042 & 10501 & 114.67 \\
\hline & Primary & 2494 & 2091 & 119.27 \\
\hline & Secondary & 2198 & 1909 & 115.14 \\
\hline & Higher & 835 & 732 & 114.07 \\
\hline Partner/Husband & No Education & 7084 & 6114 & 115.87 \\
\hline \multirow{3}{*}{ Level of Education* } & Primary & 2867 & 2444 & 117.31 \\
\hline & Secondary & 5334 & 4600 & 115.96 \\
\hline & Higher & 2262 & 2056 & 110.02 \\
\hline \multirow[t]{5}{*}{ Economic Status } & Poorest & 3425 & 3024 & 113.26 \\
\hline & Poorer & 3684 & 3117 & 118.19 \\
\hline & Middle & 3894 & 3316 & 117.43 \\
\hline & Richer & 3404 & 3009 & 113.13 \\
\hline & Richest & 3161 & 2765 & 114.32 \\
\hline Last birth & & 3628 & 2720 & 133.38 \\
\hline
\end{tabular}

Note: We have considered only those respondents who completed their childbearing.

*This portion skips the respondents who don't have knowledge of their spouse education level. 
Table 2: Parity progression ratio

\begin{tabular}{lllll}
\hline $\begin{array}{l}\text { Number of } \\
\text { children }\end{array}$ & Number of boys & $\begin{array}{l}\text { Number of } \\
\text { families with n } \\
\text { children }\end{array}$ & $\begin{array}{l}\text { Number of } \\
\text { Families with } \\
\text { n+1 Children }\end{array}$ & $\begin{array}{l}\text { Parity } \\
\text { Progression ratio } \\
\text { (PPR) }\end{array}$ \\
\hline $\mathbf{1}$ & 0 & 2916 & 2869 & 0.98 \\
& 0 & 3432 & 3362 & 0.98 \\
$\mathbf{2}$ & 1 & 1283 & 1241 & 0.97 \\
& 0 & 3168 & 2862 & 0.90 \\
$\mathbf{3}$ & 1 & 1779 & 1593 & 0.90 \\
& 2 & 542 & 509 & 0.94 \\
& 0 & 2053 & 1799 & 0.88 \\
& 1 & 2320 & 1793 & 0.77 \\
\hline Source: Authors' calculations using PDHS 2012-2013 & 777 & 649 & 0.84 \\
\hline
\end{tabular}

Source: Authors' calculations using PDHS 2012-2013.

Note: We have considered only those respondents who completed their childbearing. $\mathrm{PPR}=$ Number of families with $\mathrm{n}+1$ children/Number of families with $\mathrm{n}$ children. 
Figure 3: Top ten populous countries ranked according to Gender Inequality Index 2014

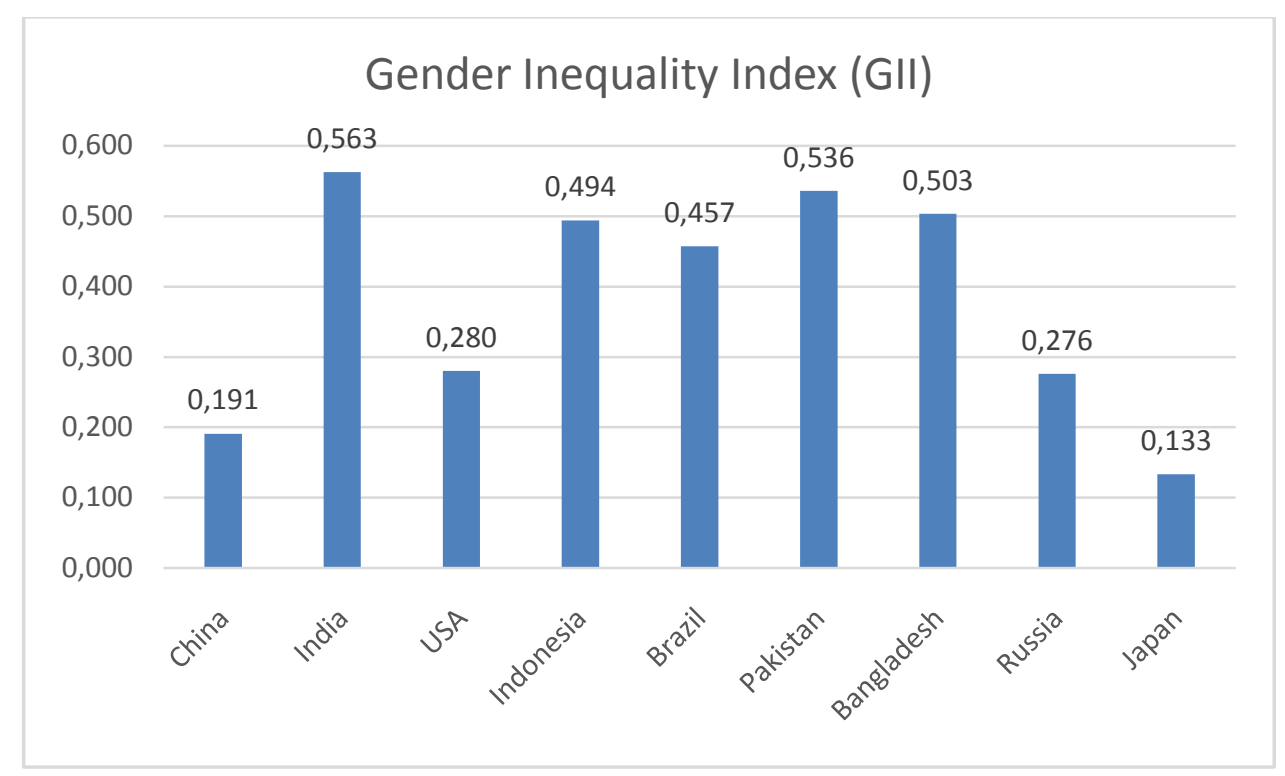

Source: Gender Inequality Index 2014 
Table 3: Household decision making

\begin{tabular}{|c|c|c|c|c|c|c|c|c|c|c|c|c|c|c|c|c|c|}
\hline & & \multicolumn{4}{|c|}{ Healthcare decisions } & \multicolumn{4}{|c|}{ Social decisions } & \multicolumn{4}{|c|}{ Consumption decisions } & \multicolumn{4}{|c|}{ Financial decisions } \\
\hline & & $\begin{array}{l}\text { Family } \\
\text { elders }\end{array}$ & Husband & Jointly & Alone & $\begin{array}{l}\text { Family } \\
\text { elders }\end{array}$ & Husband & Jointly & Alone & $\begin{array}{l}\text { Family } \\
\text { elders }\end{array}$ & Husband & Jointly & Alone & $\begin{array}{l}\text { Family } \\
\text { elders }\end{array}$ & Husband & Jointly & Alone \\
\hline & Overall & 0.11 & 0.33 & 0.45 & 0.09 & 0.17 & 0.29 & 0.46 & 0.07 & 0.17 & 0.31 & 0.44 & 0.06 & 0.01 & 0.41 & 0.49 & 0.06 \\
\hline \multirow[t]{3}{*}{ Age } & $15-24$ & 0.30 & 0.32 & 0.34 & 0.03 & 0.40 & 0.25 & 0.30 & 0.03 & 0.42 & 0.27 & 0.28 & 0.02 & 0.02 & 0.44 & 0.48 & 0.04 \\
\hline & $25-34$ & 0.13 & 0.35 & 0.42 & 0.08 & 0.21 & 0.30 & 0.42 & 0.05 & 0.21 & 0.33 & 0.40 & 0.05 & 0.00 & 0.45 & 0.47 & 0.06 \\
\hline & $35-49$ & 0.03 & 0.32 & 0.51 & 0.12 & 0.05 & 0.28 & 0.55 & 0.09 & 0.05 & 0.32 & 0.52 & 0.09 & 0.01 & 0.38 & 0.51 & 0.08 \\
\hline \multirow[t]{4}{*}{ Education } & None & 0.10 & 0.39 & 0.43 & 0.07 & 0.14 & 0.35 & 0.43 & 0.06 & 0.14 & 0.37 & 0.42 & 0.05 & 0.01 & 0.45 & 0.47 & 0.06 \\
\hline & Primary & 0.15 & 0.29 & 0.45 & 0.08 & 0.20 & 0.23 & 0.48 & 0.07 & 0.22 & 0.27 & 0.42 & 0.07 & 0.00 & 0.38 & 0.54 & 0.07 \\
\hline & Secondary & 0.13 & 0.24 & 0.48 & 0.13 & 0.21 & 0.22 & 0.48 & 0.08 & 0.22 & 0.23 & 0.46 & 0.08 & 0.01 & 0.35 & 0.54 & 0.08 \\
\hline & Higher & 0.08 & 0.19 & 0.54 & 0.17 & 0.18 & 0.14 & 0.58 & 0.09 & 0.19 & 0.16 & 0.54 & 0.09 & 0.00 & 0.34 & 0.55 & 0.09 \\
\hline Spouse & None & 0.09 & 0.38 & 0.44 & 0.08 & 0.13 & 0.35 & 0.43 & 0.07 & 0.13 & 0.37 & 0.41 & 0.08 & 0.01 & 0.44 & 0.47 & 0.07 \\
\hline \multirow[t]{3}{*}{ Education } & Primary & 0.13 & 0.36 & 0.41 & 0.08 & 0.18 & 0.27 & 0.46 & 0.07 & 0.18 & 0.32 & 0.42 & 0.05 & 0.01 & 0.41 & 0.50 & 0.07 \\
\hline & Secondary & 0.14 & 0.29 & 0.46 & 0.09 & 0.19 & 0.26 & 0.47 & 0.06 & 0.20 & 0.27 & 0.45 & 0.06 & 0.01 & 0.39 & 0.51 & 0.07 \\
\hline & Higher & 0.10 & 0.28 & 0.49 & 0.11 & 0.18 & 0.23 & 0.51 & 0.07 & 0.17 & 0.26 & 0.49 & 0.06 & 0.01 & 0.40 & 0.51 & 0.06 \\
\hline Place of & Rural & 0.12 & 0.38 & 0.42 & 0.06 & 0.17 & 0.33 & 0.43 & 0.05 & 0.17 & 0.36 & 0.41 & 0.05 & 0.01 & 0.44 & 0.48 & 0.05 \\
\hline Residence & Urban & 0.10 & 0.25 & 0.50 & 0.14 & 0.16 & 0.21 & 0.52 & 0.09 & 0.17 & 0.24 & 0.49 & 0.09 & 0.00 & 0.36 & 0.52 & 0.10 \\
\hline Family & Joint & 0.34 & 0.28 & 0.32 & 0.05 & 0.48 & 0.20 & 0.26 & 0.04 & 0.49 & 0.21 & 0.25 & 0.03 & 0.02 & 0.48 & 0.44 & 0.05 \\
\hline Structure & Nuclear & 0.02 & 0.35 & 0.50 & 0.10 & 0.04 & 0.32 & 0.54 & 0.08 & 0.04 & 0.35 & 0.51 & 0.08 & 0.01 & 0.40 & 0.51 & 0.07 \\
\hline Women & No & 0.13 & 0.34 & 0.43 & 0.08 & 0.19 & 0.29 & 0.44 & 0.06 & 0.20 & 0.32 & 0.41 & 0.06 & 0.01 & 0.43 & 0.47 & 0.06 \\
\hline Employed & Yes & 0.06 & 0.32 & 0.49 & 0.11 & 0.10 & 0.27 & 0.52 & 0.08 & 0.09 & 0.31 & 0.51 & 0.07 & 0.00 & 0.36 & 0.54 & 0.07 \\
\hline Economic & Poorest & 0.08 & 0.48 & 0.36 & 0.05 & 0.13 & 0.44 & 0.36 & 0.05 & 0.12 & 0.49 & 0.34 & 0.03 & 0.01 & 0.56 & 0.38 & 0.03 \\
\hline \multirow[t]{4}{*}{ Status } & Poorer & 0.10 & 0.36 & 0.46 & 0.06 & 0.14 & 0.32 & 0.46 & 0.05 & 0.15 & 0.34 & 0.44 & 0.05 & 0.01 & 0.40 & 0.52 & 0.05 \\
\hline & Middle & 0.13 & 0.32 & 0.45 & 0.09 & 0.17 & 0.28 & 0.46 & 0.07 & 0.18 & 0.29 & 0.44 & 0.07 & 0.01 & 0.37 & 0.53 & 0.08 \\
\hline & Rich & 0.15 & 0.25 & 0.47 & 0.11 & 0.20 & 0.22 & 0.49 & 0.07 & 0.21 & 0.24 & 0.45 & 0.08 & 0.01 & 0.38 & 0.51 & 0.09 \\
\hline & Richest & 0.10 & 0.24 & 0.50 & 0.14 & 0.18 & 0.18 & 0.53 & 0.09 & 0.19 & 0.21 & 0.50 & 0.08 & 0.01 & 0.35 & 0.54 & 0.08 \\
\hline \multirow[t]{6}{*}{ Region } & Islamabad & 0.05 & 0.32 & 0.47 & 0.14 & 0.12 & 0.21 & 0.55 & 0.09 & 0.12 & 0.24 & 0.54 & 0.08 & 0.00 & 0.38 & 0.52 & 0.08 \\
\hline & Punjab & 0.11 & 0.26 & 0.51 & 0.11 & 0.16 & 0.21 & 0.54 & 0.07 & 0.16 & 0.23 & 0.52 & 0.08 & 0.01 & 0.31 & 0.58 & 0.08 \\
\hline & Sindh & 0.09 & 0.37 & 0.43 & 0.09 & 0.16 & 0.33 & 0.41 & 0.09 & 0.17 & 0.39 & 0.37 & 0.06 & 0.00 & 0.50 & 0.43 & 0.05 \\
\hline & KPK & 0.18 & 0.45 & 0.30 & 0.05 & 0.23 & 0.40 & 0.31 & 0.04 & 0.25 & 0.40 & 0.30 & 0.04 & 0.02 & 0.55 & 0.37 & 0.04 \\
\hline & Gilgit & 0.10 & 0.51 & 0.31 & 0.07 & 0.16 & 0.40 & 0.36 & 0.07 & 0.20 & 0.48 & 0.30 & 0.01 & 0.10 & 0.66 & 0.22 & 0.01 \\
\hline & Balochistan & 0.08 & 0.66 & 0.23 & 0.01 & 0.12 & 0.63 & 0.21 & 0.02 & 0.12 & 0.66 & 0.20 & 0.01 & 0.00 & 0.74 & 0.23 & 0.01 \\
\hline
\end{tabular}

Source: Authors' calculations using PDHS 2012-2013. 
Table 4: Data description

\begin{tabular}{|c|c|c|}
\hline Variable & Description & Proportion/Mean \\
\hline Healthcare & $\begin{array}{l}\text { Person who usually decides on respondent's health care } \\
\text { 0-Family elders or husband/partner alone } \\
\text { 1- Respondent and husband/partner or respondent alone }\end{array}$ & $\begin{array}{l}0.39 \\
0.60\end{array}$ \\
\hline Family/relative visits & $\begin{array}{l}\text { Person who usually decides on visits to family or relatives } \\
0 \text {-Family elders or husband/partner alone } \\
\text { 1- Respondent and husband/partner or respondent alone }\end{array}$ & $\begin{array}{l}0.38 \\
0.61\end{array}$ \\
\hline $\begin{array}{l}\text { Large household } \\
\text { purchasing }\end{array}$ & $\begin{array}{l}\text { Person who usually decides on large household purchases } \\
\text { 0-Family elders or husband/partner alone } \\
\text { 1- Respondent and husband/partner or respondent alone }\end{array}$ & $\begin{array}{l}0.41 \\
0.58\end{array}$ \\
\hline $\begin{array}{l}\text { Spending of husband } \\
\text { income }\end{array}$ & $\begin{array}{l}\text { Person who usually decides what to do with money husband earns } \\
\text { 0-Family elders or husband/partner alone } \\
\text { 1- Respondent and husband/partner or respondent alone }\end{array}$ & $\begin{array}{l}0.42 \\
0.57\end{array}$ \\
\hline Son & $\begin{array}{l}\text { Dummy variable, takes the value of } 1 \text { if female have at least } 1 \text { son, } 0 \\
\text { otherwise }\end{array}$ & $\begin{array}{l}0.86 \\
0.13\end{array}$ \\
\hline Son & $\begin{array}{l}\text { Categorical form, takes the value of } 0 \text { if female don't have son, } 1 \text { if } \\
\text { female have } 1 \text { son, } 2 \text { if female have } 2 \text { sons, } 3 \text { if female have } 3 \text { sons, } 4 \\
\text { otherwise }\end{array}$ & $\begin{array}{l}0.13 \\
0.29 \\
0.26 \\
0.16 \\
0.14\end{array}$ \\
\hline Age & Age of the female in completed years & 34.48 \\
\hline Age difference & Age difference of husband with his wife in years & 5.38 \\
\hline Education & $\begin{array}{l}\text { Categorical form, female higher education level takes the value } 0 \text { if } \\
\text { female with none education, } 1 \text { if female have primary, } 2 \text { if female have } \\
\text { secondary education, } 3 \text { if female have higher education }\end{array}$ & $\begin{array}{l}0.58 \\
0.15 \\
0.16 \\
0.08\end{array}$ \\
\hline Spouse education & $\begin{array}{l}\text { Categorical form, husband education level takes the value } 0 \text { if } \\
\text { respondent husband with none education, } 1 \text { if husband have primary, } 2 \text { if } \\
\text { husband have secondary education, } 3 \text { if husband have higher education }\end{array}$ & $\begin{array}{l}0.34 \\
0.16 \\
0.31 \\
0.16\end{array}$ \\
\hline Women employed & $\begin{array}{l}\text { Dummy variable, takes the value of } 1 \text { if the female is employed, } 0 \\
\text { otherwise }\end{array}$ & $\begin{array}{l}0.27 \\
0.72\end{array}$ \\
\hline Media exposure & $\begin{array}{l}\text { Categorical form, female frequency of watching television, takes the } \\
\text { value } 0 \text { if female don't watch television, } 1 \text { if female watch television } \\
\text { occasionally, } 2 \text { if female watch television weekly, } 3 \text { if female watch } \\
\text { television daily }\end{array}$ & $\begin{array}{l}0.31 \\
0.21 \\
0.02 \\
0.44\end{array}$ \\
\hline Family structure & $\begin{array}{l}\text { Dummy variable, takes the value of } 1 \text { if the family is nuclear, } 0 \\
\text { otherwise }\end{array}$ & $\begin{array}{l}0.71 \\
0.28\end{array}$ \\
\hline Household size & Total number of family members in the household & 8.58 \\
\hline Place of residence & $\begin{array}{l}\text { Dummy variable, takes the value of } 1 \text { if the household resides in urban } \\
\text { area, } 0 \text { otherwise }\end{array}$ & $\begin{array}{l}0.35 \\
0.64\end{array}$ \\
\hline Region & $\begin{array}{l}\text { Categorical form, takes the value } 1 \text { if household lives in Islamabad, } 2 \text { if } \\
\text { household lives in Punjab, } 3 \text { if household lives in Sindh, } 4 \text { if household } \\
\text { lives in KPK, } 5 \text { if household lives in Gilgit Baltistan, Baluchistan } \\
\text { otherwise } 6\end{array}$ & $\begin{array}{l}0.005 \\
0.56 \\
0.25 \\
0.12 \\
0.007 \\
0.048\end{array}$ \\
\hline Economic Status & $\begin{array}{l}\text { Categorical form, takes the value } 1 \text { if household in poorest, } 2 \text { if } \\
\text { household is poorer, } 3 \text { if household is middle, } 4 \text { if household is rich, } \\
\text { richest otherwise } 5\end{array}$ & $\begin{array}{l}0.20 \\
0.18 \\
0.19 \\
0.20 \\
0.21\end{array}$ \\
\hline
\end{tabular}

Source: Authors’ calculations using PDHS 2012-2013. 
Table 5: Son preference and female participation in decisionmaking - probit estimation

\begin{tabular}{|c|c|c|c|c|c|}
\hline VARIABLES & Healthcare decisions & Social decisions & $\begin{array}{c}\text { Consumption } \\
\text { decisions }\end{array}$ & Financial decisions & All decisions \\
\hline \multicolumn{6}{|l|}{ Sons (ref: none) } \\
\hline At least one son & $0.149 * * *(0.051)$ & $0.208 * * *(0.055)$ & $0.169 * * *(0.058)$ & $0.048(0.061)$ & $0.223^{* * *}(0.068)$ \\
\hline Age & $0.024 * * *(0.003)$ & $0.029 * * *(0.003)$ & $0.029 * * *(0.003)$ & $0.006^{* *}(0.003)$ & $0.017 * * *(0.003)$ \\
\hline Age difference & $0.008 * *(0.004)$ & $0.011^{* * *}(0.003)$ & $0.009 * *(0.004)$ & $-0.002(0.004)$ & $0.002(0.005)$ \\
\hline \multicolumn{6}{|c|}{ Women education (ref: none) } \\
\hline Primary & $0.059(0.051)$ & $0.137 * *(0.058)$ & $0.028(0.055)$ & $0.054(0.069)$ & $0.122 *(0.070)$ \\
\hline Secondary & $0.239 * * *(0.073)$ & $0.131 *(0.067)$ & $0.119 *(0.070)$ & $0.089(0.088)$ & $0.276 * * *(0.097)$ \\
\hline Higher & $0.428 * * *(0.096)$ & $0.346 * * *(0.099)$ & $0.312 * * *(0.095)$ & $0.158(0.107)$ & $0.592 * * *(0.111)$ \\
\hline \multicolumn{6}{|c|}{ Spouse education (ref: none) } \\
\hline Primary & $-0.140 * *(0.061)$ & $-0.007(0.059)$ & $-0.064(0.064)$ & $-0.077(0.068)$ & $-0.046(0.066)$ \\
\hline Secondary & $-0.029(0.054)$ & $-0.022(0.057)$ & $-0.027(0.055)$ & $-0.084(0.057)$ & $-0.049(0.058)$ \\
\hline Higher & $0.007(0.068)$ & $0.027(0.072)$ & $0.025(0.078)$ & $-0.100(0.072)$ & $-0.012(0.086)$ \\
\hline \multicolumn{6}{|c|}{ Women employed (ref: none) } \\
\hline Yes & $0.199 * * *(0.048)$ & $0.221^{* * *}(0.043)$ & $0.260 * * *(0.048)$ & $0.184 * * *(0.055)$ & $0.261^{* * *}(0.054)$ \\
\hline \multicolumn{6}{|c|}{ Media exposure (ref: none) } \\
\hline Occasionally & $0.118 *(0.061)$ & $0.099(0.060)$ & $0.116 *(0.069)$ & $0.089(0.063)$ & $0.212 * * *(0.066)$ \\
\hline Weekly & $-0.043(0.113)$ & $-0.005(0.119)$ & $0.123(0.106)$ & $-0.069(0.141)$ & $0.136(0.140)$ \\
\hline Daily & $0.141^{* *}(0.056)$ & $0.121^{* *}(0.055)$ & $0.160 * * *(0.055)$ & $0.100 *(0.058)$ & $0.179 * * *(0.065)$ \\
\hline \multicolumn{6}{|c|}{ Family structure (ref: joint) } \\
\hline Nuclear family & $0.291^{* * *}(0.053)$ & $0.444 * * *(0.062)$ & $0.393 * * *(0.058)$ & $0.082(0.064)$ & $-0.069(0.075)$ \\
\hline Household size & $-0.030 * * *(0.006)$ & $-0.039 * * *(0.007)$ & $-0.047 * * *(0.007)$ & $-0.019 * * *(0.006)$ & $-0.035 * * *(0.008)$ \\
\hline \multicolumn{6}{|c|}{ Place of residence (ref: rural) } \\
\hline Urban & $0.216 * * *(0.066)$ & $0.160 * * *(0.058)$ & $0.172 * * *(0.059)$ & $0.118 *(0.068)$ & $0.139 *(0.082)$ \\
\hline \multicolumn{6}{|c|}{ Province/ Region (ref: Islamabad) } \\
\hline Punjab & $0.299 * * *(0.079)$ & $0.173^{* * *}(0.062)$ & $0.176^{* *}(0.075)$ & $0.256^{* * *}(0.086)$ & $0.265^{* * *}(0.092)$ \\
\hline Sindh & $0.042(0.089)$ & $-0.140 *(0.073)$ & $-0.279 * * *(0.084)$ & $-0.152(0.096)$ & $-0.274 * * *(0.095)$ \\
\hline KPK region & $-0.257 * * *(0.092)$ & $-0.384 * * *(0.079)$ & $-0.352 * * *(0.091)$ & $-0.282^{* * *}(0.100)$ & $-0.379 * * *(0.102)$ \\
\hline Gilgit-Baltistan & $-0.151(0.160)$ & $-0.114(0.163)$ & $-0.421 * * *(0.133)$ & $-0.693 * * *(0.137)$ & $-0.475 * * *(0.180)$ \\
\hline Balochistan & $-0.451 * * *(0.128)$ & $-0.545 * * *(0.120)$ & $-0.582 * * *(0.130)$ & $-0.618 * * *(0.131)$ & $-0.848 * * *(0.135)$ \\
\hline \multicolumn{6}{|c|}{ Economic status (ref: poorest) } \\
\hline Poorer & $0.210 * * *(0.063)$ & $0.215 * * *(0.065)$ & $0.223^{* * *}(0.064)$ & $0.313^{* * *}(0.064)$ & $0.169 *(0.086)$ \\
\hline Middle & $0.119(0.081)$ & $0.139 *(0.072)$ & $0.155^{* *}(0.071)$ & $0.327 * * *(0.083)$ & $0.225 * * *(0.082)$ \\
\hline Rich & $0.116(0.090)$ & $0.140 *(0.077)$ & $0.148 *(0.079)$ & $0.237 * *(0.093)$ & $0.191 * *(0.095)$ \\
\hline Richest & $0.066(0.109)$ & $0.156(0.098)$ & $0.122(0.097)$ & $0.270 * *(0.120)$ & $0.257 * *(0.114)$ \\
\hline Marginal effect & $0.052 * * *(0.018)$ & $0.070 * * *(0.018)$ & $0.057 * * *(0.019)$ & $0.017(0.022)$ & $0.064 * * *(0.020)$ \\
\hline Constant & $-1.282 * * *(0.140)$ & $-1.459 * * *(0.137)$ & $-1.395 * * *(0.148)$ & $-0.374 * *(0.155)$ & $-0.212(0.154)$ \\
\hline Observations & 10,017 & 10,035 & 10,026 & 8,532 & 8,497 \\
\hline
\end{tabular}

Source: Authors' calculations. Standard errors in parentheses ${ }^{* * *} \mathrm{p}<0.01,{ }^{* *} \mathrm{p}<0.05,{ }^{*} \mathrm{p}<0.1$ 
Table 6: Number of sons and female participation in decision making - probit estimation

\begin{tabular}{|c|c|c|c|c|c|}
\hline VARIABLES & $\begin{array}{c}\text { Healthcare } \\
\text { decision }\end{array}$ & Social decisions & $\begin{array}{c}\text { Consumption } \\
\text { decisions }\end{array}$ & $\begin{array}{l}\text { Financial } \\
\text { decisions }\end{array}$ & All decisions \\
\hline \multicolumn{6}{|l|}{ Sons (ref: 0) } \\
\hline 1 & $0.139 * *(0.057)$ & $0.165 * * *(0.058)$ & $0.131 * *(0.062)$ & $0.051(0.065)$ & $0.202^{* * *}(0.071)$ \\
\hline 2 & $0.154^{* * *}(0.059)$ & $0.254 * * *(0.065)$ & $0.213^{* * *}(0.068)$ & $0.061(0.072)$ & $0.263 * * *(0.078)$ \\
\hline 3 & $0.179 * * *(0.062)$ & $0.235 * * *(0.071)$ & $0.208 * * *(0.070)$ & $0.028(0.079)$ & $0.225 * * *(0.083)$ \\
\hline $3+$ & $0.144 * *(0.070)$ & $0.270 * * *(0.071)$ & $0.180 * *(0.082)$ & $0.015(0.082)$ & $0.174 *(0.091)$ \\
\hline Age & $0.023 * * *(0.003)$ & $0.027 * * *(0.003)$ & $0.028 * * *(0.003)$ & $0.006 * *(0.003)$ & $0.018 * * *(0.004)$ \\
\hline Age difference & $0.008 * *(0.004)$ & $0.011 * * *(0.003)$ & $0.009 * *(0.004)$ & $-0.002(0.004)$ & $0.002(0.005)$ \\
\hline \multicolumn{6}{|c|}{ Women education (ref: none) } \\
\hline Primary & $0.060(0.051)$ & $0.138 * *(0.057)$ & $0.028(0.055)$ & $0.053(0.068)$ & $0.121 *(0.070)$ \\
\hline Secondary & $0.240 * * *(0.073)$ & $0.137 * *(0.067)$ & $0.123 *(0.071)$ & $0.088(0.087)$ & $0.279 * * *(0.096)$ \\
\hline Higher & $0.431^{* * *}(0.095)$ & $0.357 * * *(0.099)$ & $0.320 * * *(0.096)$ & $0.156(0.107)$ & $0.594^{* * *}(0.112)$ \\
\hline \multicolumn{6}{|c|}{ Spouse education (ref: none) } \\
\hline Primary & $-0.139 * *(0.061)$ & $-0.007(0.059)$ & $-0.063(0.064)$ & $-0.078(0.068)$ & $-0.047(0.066)$ \\
\hline Secondary & $-0.028(0.055)$ & $-0.021(0.056)$ & $-0.026(0.055)$ & $-0.087(0.058)$ & $-0.053(0.058)$ \\
\hline Higher & $0.009(0.067)$ & $0.027(0.072)$ & $0.025(0.078)$ & $-0.103(0.073)$ & $-0.015(0.086)$ \\
\hline \multicolumn{6}{|c|}{ Women employed (ref: none) } \\
\hline Yes & $0.199 * * *(0.048)$ & $0.220 * * *(0.043)$ & $0.259 * * *(0.047)$ & $0.183^{* * *}(0.055)$ & $0.260 * * *(0.054)$ \\
\hline \multicolumn{6}{|c|}{ Media exposure (ref: none) } \\
\hline Occasionally & $0.118 *(0.061)$ & $0.096(0.061)$ & $0.115 *(0.069)$ & $0.089(0.063)$ & $0.213 * * *(0.066)$ \\
\hline Weekly & $-0.045(0.113)$ & $-0.007(0.119)$ & $0.123(0.107)$ & $-0.066(0.140)$ & $0.137(0.140)$ \\
\hline Daily & $0.140 * *(0.056)$ & $0.120 * *(0.055)$ & $0.159 * * *(0.055)$ & $0.100 *(0.058)$ & $0.179 * * *(0.066)$ \\
\hline \multicolumn{6}{|c|}{ Family structure (ref: joint) } \\
\hline Nuclear family & $0.288 * * *(0.055)$ & $0.429 * * *(0.064)$ & $0.382 * * *(0.060)$ & $0.087(0.066)$ & $-0.066(0.077)$ \\
\hline Household size & $-0.030 * * *(0.007)$ & $-0.041 * * *(0.007)$ & $-0.048 * * *(0.007)$ & $-0.018 * * *(0.007)$ & $-0.035 * * *(0.008)$ \\
\hline \multicolumn{6}{|c|}{ Place of residence (ref: rural) } \\
\hline Urban & $0.216 * * *(0.066)$ & $0.159 * * *(0.058)$ & $0.172 * * *(0.059)$ & $0.118 *(0.068)$ & $0.139 *(0.082)$ \\
\hline \multicolumn{6}{|c|}{ Province/ Region (ref: Islamabad) } \\
\hline Punjab & $0.299 * * *(0.079)$ & $0.171 * * *(0.062)$ & $0.175^{* *}(0.075)$ & $0.257 * * *(0.086)$ & $0.265 * * *(0.092)$ \\
\hline Sindh & $0.043(0.089)$ & $-0.141 *(0.074)$ & $-0.278 * * *(0.084)$ & $-0.152(0.096)$ & $-0.274 * * *(0.095)$ \\
\hline KPK & $-0.259 * * *(0.092)$ & $-0.388 * * *(0.079)$ & $-0.355 * * *(0.091)$ & $-0.281 * * *(0.100)$ & $-0.381 * * *(0.102)$ \\
\hline Gilgit-Baltistan & $-0.154(0.160)$ & $-0.124(0.163)$ & $-0.429 * * *(0.133)$ & $-0.693 * * *(0.137)$ & $-0.480 * * *(0.180)$ \\
\hline Balochistan & $-0.452 * * *(0.128)$ & $-0.547 * * *(0.120)$ & $-0.584 * * *(0.130)$ & $-0.618 * * *(0.131)$ & $-0.850 * * *(0.135)$ \\
\hline \multicolumn{6}{|c|}{ Economic status (ref: poorest) } \\
\hline Poorer & $0.208 * * *(0.063)$ & $0.215^{* * *}(0.064)$ & $0.222 * * *(0.064)$ & $0.313^{* * *}(0.063)$ & $0.168 *(0.085)$ \\
\hline Middle & $0.118(0.081)$ & $0.140 *(0.072)$ & $0.154 * *(0.071)$ & $0.327 * * *(0.083)$ & $0.223^{* * *}(0.082)$ \\
\hline Rich & $0.115(0.090)$ & $0.141 *(0.077)$ & $0.147 *(0.079)$ & $0.235^{* *}(0.093)$ & $0.188 * *(0.096)$ \\
\hline Richest & $0.065(0.109)$ & $0.161 *(0.098)$ & $0.123(0.097)$ & $0.267 * *(0.121)$ & $0.251^{* *}(0.114)$ \\
\hline $\begin{array}{l}\text { Marginal Effect: } \\
1\end{array}$ & $0.048 * *(0.020)$ & $0.056 * * *(0.019)$ & $0.044 * * *(0.021)$ & $0.018(0.023)$ & $0.058 * * *(0.021)$ \\
\hline 2 & $0.054 * * *(0.020)$ & $0.086 * * *(0.022)$ & $0.072 * * *(0.023)$ & $0.022(0.026)$ & $0.075^{* * *}(0.023)$ \\
\hline 3 & $0.062 * * *(0.021)$ & $0.080 * * *(0.024)$ & $0.070 * *(0.023)$ & $0.010(0.028)$ & $0.065 *(0.024)$ \\
\hline $3+$ & $0.050 * *(0.024)$ & $0.092 * * *(0.024)$ & $0.060 * *(0.027)$ & $0.005(0.030)$ & $0.050 *(0.026)$ \\
\hline Constant & $-1.271^{* *}(0.149)$ & $-1.392 * * *(0.145)$ & $-1.354 * * *(0.156)$ & $-0.399 * *(0.163)$ & $-0.226(0.162)$ \\
\hline Observations & 10,017 & 10,035 & 10,026 & 8,532 & 8,497 \\
\hline
\end{tabular}

Source: Authors' calculations.

Standard errors in parentheses

*** $\mathrm{p}<0.01,{ }^{* *} \mathrm{p}<0.05,{ }^{*} \mathrm{p}<0.1$ 
Table 7: Son preference and female participation in decisionmaking (parity wise) - probit estimation

\begin{tabular}{|c|c|c|c|c|c|c|c|c|c|c|}
\hline \multirow[t]{2}{*}{ VARIABLES } & \multicolumn{2}{|c|}{ Healthcare decisions } & \multicolumn{2}{|c|}{ Social decisions } & \multicolumn{2}{|c|}{ Consumption decisions } & \multicolumn{2}{|c|}{ Financial decisions } & \multicolumn{2}{|c|}{ All decisions } \\
\hline & $($ Parity $\leq 3)$ & (Parity $>3$ ) & $($ Parity $\leq 3)$ & (Parity>3) & $($ Parity $\leq 3)$ & (Parity $>3)$ & $($ Parity $\leq 3)$ & (Parity $>3)$ & $($ Parity $\leq 3)$ & (Parity > 3) \\
\hline \multicolumn{11}{|l|}{ Sons (ref: none) } \\
\hline At least one son & $0.156^{* * *}(0.059)$ & $0.088(0.228)$ & $0.224 * * *(0.063)$ & $0.057(0.240)$ & $0.168 * * *(0.064)$ & $0.134(0.152)$ & $0.020(0.068)$ & $0.175(0.214)$ & $0.226^{* * *}(0.076)$ & $0.205(0.238)$ \\
\hline Age & $0.026 * * *(0.004)$ & $0.018^{* * *}(0.004)$ & $0.030 * * *(0.004)$ & $0.024 * * *(0.005)$ & $0.031^{* * *}(0.004)$ & $0.024 * * *(0.005)$ & $0.007 *(0.004)$ & $0.003(0.005)$ & $0.012 * * *(0.005)$ & $0.019 * * *(0.006)$ \\
\hline Age difference & $0.016 * * *(0.005)$ & $0.002(0.005)$ & $0.023^{* * *}(0.005)$ & $0.003(0.005)$ & $0.016 * * *(0.005)$ & $0.003(0.005)$ & $-0.004(0.005)$ & $0.001(0.005)$ & $0.003(0.006)$ & $0.001(0.006)$ \\
\hline \multicolumn{11}{|c|}{ Women education (ref: none) } \\
\hline Primary & $0.056(0.074)$ & $0.083(0.068)$ & $0.076(0.085)$ & $0.247 * * *(0.081)$ & $0.036(0.086)$ & $0.044(0.075)$ & $-0.006(0.111)$ & $0.120(0.089)$ & $0.097(0.109)$ & $0.161 *(0.095)$ \\
\hline Secondary & $0.335^{* * *}(0.087)$ & $0.162(0.103)$ & $0.239^{* * *}(0.077)$ & $0.030(0.103)$ & $0.236^{* * *}(0.086)$ & $0.028(0.106)$ & $0.170 *(0.100)$ & $0.002(0.114)$ & $0.328 * * *(0.110)$ & $0.219 *(0.122)$ \\
\hline Higher & $0.653 * * *(0.104)$ & $0.028(0.169)$ & $0.413^{* * *}(0.107)$ & $0.312^{* *}(0.157)$ & $0.449 * * *(0.115)$ & $0.140(0.158)$ & $0.182(0.128)$ & $0.181(0.158)$ & $0.615^{* * *}(0.129)$ & $0.525^{* * *}(0.175)$ \\
\hline \multicolumn{11}{|c|}{ Spouse education (ref: none) } \\
\hline Primary & $-0.014(0.089)$ & $-0.235^{* * *}(0.075)$ & $0.068(0.083)$ & $-0.057(0.073)$ & $0.048(0.091)$ & $-0.149 *(0.076)$ & $0.027(0.092)$ & $-0.154 *(0.084)$ & $0.031(0.102)$ & $-0.100(0.081)$ \\
\hline Secondary & $0.017(0.073)$ & $-0.079(0.077)$ & $-0.042(0.077)$ & $-0.015(0.076)$ & $-0.040(0.075)$ & $-0.018(0.074)$ & $-0.107(0.077)$ & $-0.068(0.071)$ & $-0.072(0.084)$ & $-0.034(0.085)$ \\
\hline Higher & $0.024(0.085)$ & $-0.035(0.097)$ & $0.077(0.094)$ & $-0.063(0.113)$ & $0.087(0.106)$ & $-0.072(0.120)$ & $-0.110(0.097)$ & $-0.103(0.108)$ & $0.024(0.104)$ & $-0.062(0.129)$ \\
\hline \multicolumn{11}{|c|}{ Women employed (ref: none) } \\
\hline Yes & $0.179 * *(0.080)$ & $0.205^{* * *}(0.058)$ & $0.189 * *(0.080)$ & $0.231^{* * *}(0.068)$ & $0.211^{* * *}(0.077)$ & $0.285^{* * *}(0.058)$ & $0.211^{* * *}(0.080)$ & $0.169 * *(0.077)$ & $0.227^{* *}(0.089)$ & $0.287 * * *(0.077)$ \\
\hline \multicolumn{11}{|c|}{ Media exposure (ref: none) } \\
\hline Occasionally & $0.219 * *(0.086)$ & $0.044(0.082)$ & $0.184^{* *}(0.083)$ & $0.041(0.084)$ & $0.191^{* *}(0.082)$ & $0.063(0.102)$ & $0.222 * *(0.102)$ & $-0.007(0.081)$ & $0.381^{* * *}(0.101)$ & $0.089(0.085)$ \\
\hline Weekly & $-0.026(0.162)$ & $-0.044(0.177)$ & $-0.173(0.164)$ & $0.170(0.185)$ & $0.056(0.161)$ & $0.199(0.173)$ & $-0.233(0.200)$ & $0.070(0.171)$ & $0.039(0.194)$ & $0.223(0.219)$ \\
\hline Daily & $0.159 * *(0.080)$ & $0.146 * *(0.073)$ & $0.136 *(0.076)$ & $0.124(0.077)$ & $0.161^{* *}(0.073)$ & $0.184 * *(0.081)$ & $0.138(0.086)$ & $0.085(0.075)$ & $0.194 * *(0.094)$ & $0.182^{* *}(0.083)$ \\
\hline \multicolumn{11}{|c|}{ Family structure (ref: joint) } \\
\hline Nuclear family & $0.358 * * *(0.077)$ & $0.129 *(0.071)$ & $0.485^{* * *}(0.076)$ & $0.319 * * *(0.079)$ & $0.450 * * *(0.077)$ & $0.233 * * *(0.083)$ & $0.101(0.084)$ & $0.049(0.102)$ & $0.022(0.096)$ & $-0.202 *(0.114)$ \\
\hline Household size & $-0.028 * * *(0.010)$ & $-0.035^{* * *}(0.007)$ & $-0.042^{* * *}(0.010)$ & $-0.039 * * *(0.007)$ & $-0.049 * * *(0.010)$ & $-0.047 * * *(0.008)$ & $-0.014(0.009)$ & $-0.024 * * *(0.008)$ & $-0.031 * * *(0.009)$ & $-0.043^{* * *}(0.010)$ \\
\hline \multicolumn{11}{|c|}{ Place of residence (ref: rural) } \\
\hline Urban & $0.210 * *(0.082)$ & $0.214^{* *}(0.083)$ & $0.198 * * *(0.073)$ & $0.125(0.091)$ & $0.220^{* * *}(0.071)$ & $0.129(0.087)$ & $0.148(0.092)$ & $0.094(0.083)$ & $0.211 *(0.107)$ & $0.077(0.107)$ \\
\hline \multicolumn{11}{|c|}{ Province/ Region (ref: Islamabad) } \\
\hline Punjab & $0.315 * * *(0.092)$ & $0.259 * *(0.110)$ & $0.185^{* *}(0.084)$ & $0.138(0.096)$ & $0.207 * *(0.087)$ & $0.099(0.123)$ & $0.262 * *(0.104)$ & $0.244 * *(0.121)$ & $0.254 * *(0.100)$ & $0.235(0.147)$ \\
\hline Sindh & $0.167(0.102)$ & $-0.099(0.120)$ & $-0.050(0.092)$ & $-0.240 * *(0.105)$ & $-0.147(0.100)$ & $-0.444 * * *(0.127)$ & $-0.089(0.119)$ & $-0.211 *(0.126)$ & $-0.182 *(0.101)$ & $-0.390 * * *(0.149)$ \\
\hline KPK region & $-0.279 * *(0.112)$ & $-0.271^{* *}(0.123)$ & $-0.371^{* * *}(0.106)$ & $-0.416 * * *(0.111)$ & $-0.317^{* * *}(0.110)$ & $-0.426 * * *(0.137)$ & $-0.348^{* * *}(0.127)$ & $-0.254 *(0.133)$ & $-0.442 * * *(0.114)$ & $-0.383 * *(0.153)$ \\
\hline Gilgit-Baltistan & $0.064(0.180)$ & $-0.320 *(0.186)$ & $0.184(0.176)$ & $-0.319 *(0.185)$ & $-0.261 *(0.133)$ & $-0.564 * * *(0.175)$ & $-0.689 * * *(0.155)$ & $-0.716 * * *(0.173)$ & $-0.356 *(0.199)$ & $-0.584 * * *(0.214)$ \\
\hline Balochistan & $-0.199(0.150)$ & $-0.664 * * *(0.146)$ & $-0.198(0.147)$ & $-0.836^{* * *}(0.137)$ & $-0.219(0.151)$ & $-0.906 * * *(0.164)$ & $-0.479 * * *(0.170)$ & $-0.720 * * *(0.150)$ & $-0.657 * * *(0.165)$ & $-1.012 * * *(0.173)$ \\
\hline \multicolumn{11}{|c|}{ Economic status (ref: poorest) } \\
\hline Poorer & $0.206 * *(0.103)$ & $0.208^{* * *}(0.073)$ & $0.238 * * *(0.090)$ & $0.193^{* *}(0.090)$ & $0.225^{* *}(0.096)$ & $0.224^{* * *}(0.085)$ & $0.335^{* * *}(0.116)$ & $0.298^{* * *}(0.083)$ & $0.206 *(0.107)$ & $0.146(0.106)$ \\
\hline Middle & $0.047(0.109)$ & $0.185 *(0.105)$ & $0.072(0.107)$ & $0.202 * *(0.094)$ & $0.093(0.106)$ & $0.214^{* *}(0.089)$ & $0.274 * *(0.121)$ & $0.378 * * *(0.112)$ & $0.187(0.120)$ & $0.269 * *(0.104)$ \\
\hline Rich & $0.041(0.119)$ & $0.186(0.123)$ & $0.048(0.113)$ & $0.223^{* *}(0.107)$ & $0.029(0.113)$ & $0.252 * *(0.106)$ & $0.180(0.134)$ & $0.281^{* *}(0.121)$ & $0.156(0.141)$ & $0.238 *(0.127)$ \\
\hline Richest & $-0.027(0.149)$ & $0.160(0.144)$ & $0.070(0.128)$ & $0.236 *(0.133)$ & $-0.030(0.130)$ & $0.271^{* *}(0.134)$ & $0.213(0.171)$ & $0.335^{* *}(0.148)$ & $0.244(0.158)$ & $0.302 *(0.154)$ \\
\hline Marginal effect & $0.053 * * *(0.020)$ & $0.031(0.081)$ & $0.073 * * *(0.020)$ & $0.019(0.082)$ & $0.054 * * *(0.020)$ & $0.046(0.053)$ & $0.007(0.024)$ & $0.063(0.078)$ & $0.064 * * *(0.022)$ & $0.059(0.072)$ \\
\hline Constant & $-1.579 * * *(0.201)$ & $-0.696 * *(0.309)$ & $-1.657 * * *(0.194)$ & $-0.907 * * *(0.307)$ & $-1.634 * * *(0.208)$ & $-0.856 * * *(0.282)$ & $-0.498 * *(0.228)$ & $-0.283(0.323)$ & $-0.291(0.209)$ & $0.012(0.374)$ \\
\hline Observations & 4,906 & 5,111 & 4,909 & 5,126 & 4,908 & 5,118 & 3,789 & 4,743 & 3,778 & 4,719 \\
\hline
\end{tabular}

Source: Authors' calculations.

Standard errors in parentheses
$* * *$ p $<0.01, * * p<0.05, * p<0.1$ 
Table 8: Sex at last birth and female participation in decisionmaking - probit estimation

\begin{tabular}{|c|c|c|c|c|c|}
\hline & $\begin{array}{l}\text { Healthcare } \\
\text { decisions }\end{array}$ & Social decisions & $\begin{array}{l}\text { Consumption } \\
\text { decisions }\end{array}$ & $\begin{array}{l}\text { Financial } \\
\text { decisions }\end{array}$ & All decisions \\
\hline \multicolumn{6}{|c|}{ Sex at last birth (ref: female) } \\
\hline $\begin{array}{l}\text { Male } \\
\text { Age } \\
\text { Age difference } \\
\text { Women educati }\end{array}$ & $\begin{array}{l}0.010(0.036) \\
0.025^{* * *}(0.003) \\
0.008^{* *}(0.004) \\
\text { (ref: none) }\end{array}$ & $\begin{array}{l}0.046(0.040) \\
0.030 * * *(0.003) \\
0.011^{* * *}(0.003)\end{array}$ & $\begin{array}{l}0.035(0.037) \\
0.031^{* * *}(0.003) \\
0.009^{* *}(0.004)\end{array}$ & $\begin{array}{l}-0.014(0.041) \\
0.006 * *(0.003) \\
-0.002(0.004)\end{array}$ & $\begin{array}{l}0.024(0.049) \\
0.019 * * *(0.003) \\
0.002(0.005)\end{array}$ \\
\hline $\begin{array}{l}\text { Primary } \\
\text { Secondary } \\
\text { Higher }\end{array}$ & $\begin{array}{l}0.061(0.051) \\
0.237 * * *(0.073) \\
0.420 * * *(0.095)\end{array}$ & $\begin{array}{l}0.139 * *(0.058) \\
0.129 *(0.067) \\
0.333 * * *(0.100)\end{array}$ & $\begin{array}{l}0.030(0.055) \\
0.117 *(0.071) \\
0.302 * * *(0.095)\end{array}$ & $\begin{array}{l}0.054(0.069) \\
0.089(0.088) \\
0.155(0.107)\end{array}$ & $\begin{array}{l}0.122 *(0.070) \\
0.273 * * *(0.098) \\
0.578 * * *(0.111)\end{array}$ \\
\hline \multicolumn{6}{|c|}{ Spouse education (ref: none) } \\
\hline $\begin{array}{l}\text { Primary } \\
\text { Secondary } \\
\text { Higher }\end{array}$ & $\begin{array}{l}-0.140 * *(0.061) \\
-0.031(0.055) \\
0.007(0.068)\end{array}$ & $\begin{array}{l}-0.007(0.059) \\
-0.022(0.057) \\
0.028(0.071)\end{array}$ & $\begin{array}{l}-0.064(0.064) \\
-0.027(0.055) \\
0.026(0.077)\end{array}$ & $\begin{array}{l}-0.078(0.068) \\
-0.086(0.058) \\
-0.101(0.072)\end{array}$ & $\begin{array}{l}-0.048(0.066) \\
-0.051(0.058) \\
-0.014(0.085)\end{array}$ \\
\hline \multicolumn{6}{|c|}{ Women employed (ref: none) } \\
\hline \multicolumn{6}{|c|}{ Media exposure (ref: none) } \\
\hline $\begin{array}{l}\text { Occasionally } \\
\text { Weekly } \\
\text { Daily }\end{array}$ & $\begin{array}{l}0.117 *(0.061) \\
-0.044(0.112) \\
0.143 * *(0.056)\end{array}$ & $\begin{array}{l}0.098(0.060) \\
-0.006(0.119) \\
0.124^{* *}(0.055)\end{array}$ & $\begin{array}{l}0.115 *(0.069) \\
0.122(0.107) \\
0.162 * * *(0.055)\end{array}$ & $\begin{array}{l}0.089(0.063) \\
-0.068(0.141) \\
0.101 *(0.058)\end{array}$ & $\begin{array}{l}0.212 * * *(0.066) \\
0.132(0.141) \\
0.183 * * *(0.066)\end{array}$ \\
\hline \multicolumn{6}{|c|}{ Family structure (ref: joint) } \\
\hline $\begin{array}{l}\text { Nuclear family } \\
\text { Household size } \\
\text { Place of residen }\end{array}$ & $\begin{array}{l}0.302 * * *(0.053) \\
-0.029 * * *(0.006) \\
\text { (ref: rural) }\end{array}$ & $\begin{array}{l}0.460 * * *(0.061) \\
-0.038 * * *(0.007)\end{array}$ & $\begin{array}{l}0.407 * * *(0.058) \\
-0.045 * * *(0.007)\end{array}$ & $\begin{array}{l}0.084(0.063) \\
-0.018 * * *(0.006)\end{array}$ & $\begin{array}{l}-0.050(0.072) \\
-0.033^{* * *}(0.007)\end{array}$ \\
\hline Urban & $0.213^{* * *}(0.067)$ & $0.156^{* * *}(0.059)$ & $0.170 * * *(0.060)$ & $0.117 *(0.068)$ & $0.136(0.083)$ \\
\hline \multicolumn{6}{|c|}{ Province/ Region (ref: Islamabad) } \\
\hline $\begin{array}{l}\text { Punjab } \\
\text { Sindh } \\
\text { KPK region } \\
\text { Gilgit-Baltistan } \\
\text { Balochistan } \\
\text { Economic statu }\end{array}$ & $\begin{array}{l}0.300^{* * *}(0.079) \\
0.042(0.089) \\
-0.252 * * *(0.092) \\
-0.145(0.160) \\
-0.446^{* * *}(0.128) \\
\text { (ref: poorest) }\end{array}$ & $\begin{array}{l}0.174 * * *(0.063) \\
-0.141 *(0.074) \\
-0.377 * * *(0.079) \\
-0.107(0.162) \\
-0.537 * * *(0.119)\end{array}$ & $\begin{array}{l}0.177 * *(0.075) \\
-0.280 * * *(0.084) \\
-0.347 * * *(0.091) \\
-0.413^{* * *}(0.133) \\
-0.575 * * *(0.129)\end{array}$ & $\begin{array}{l}0.257 * * *(0.086) \\
-0.152(0.096) \\
-0.281 * * *(0.100) \\
-0.691 * * *(0.137) \\
-0.617 * * *(0.131)\end{array}$ & $\begin{array}{l}0.263^{* * *}(0.092) \\
-0.276 * * *(0.094) \\
-0.374 * * *(0.101) \\
-0.467 * * *(0.179) \\
-0.842 * * *(0.134)\end{array}$ \\
\hline $\begin{array}{l}\text { Economic statu } \\
\text { Poorer } \\
\text { Middle }\end{array}$ & $\begin{array}{l}\text { (ref: poorest) } \\
0.209 * * *(0.064) \\
0.122(0.082)\end{array}$ & $\begin{array}{l}0.213 * * *(0.065) \\
0.141 *(0.072)\end{array}$ & $\begin{array}{l}0.222 * * *(0.064) \\
0.158 * *(0.071)\end{array}$ & $\begin{array}{l}0.313 * * *(0.064) \\
0.329 * * *(0.083)\end{array}$ & $\begin{array}{l}0.168 * *(0.085) \\
0.228 * * *(0.082)\end{array}$ \\
\hline Rich & $0.116(0.091)$ & $0.137 *(0.077)$ & $0.147 *(0.079)$ & $0.238 * *(0.094)$ & $0.191 * *(0.095)$ \\
\hline Richest & $0.068(0.109)$ & $0.155(0.098)$ & $0.123(0.097)$ & $0.271^{* *}(0.120)$ & $0.260 * *(0.113)$ \\
\hline $\begin{array}{l}\text { Constant } \\
\text { Observations }\end{array}$ & $\begin{array}{l}-1.224 * * *(0.138) \\
10,017\end{array}$ & $\begin{array}{l}1.391 * * *(0.139) \\
10,035\end{array}$ & $\begin{array}{l}-1.341 * * *(0.147) \\
10,026\end{array}$ & $\begin{array}{l}-0.345 * *(0.153) \\
8,532\end{array}$ & $\begin{array}{l}-0.123(0.155) \\
8,497\end{array}$ \\
\hline
\end{tabular}

Source: Authors' calculations.

Standard errors in parentheses

*** $\mathrm{p}<0.01,{ }^{* *} \mathrm{p}<0.05,{ }^{*} \mathrm{p}<0.1$ 
Table 9: Son Preference and female participation in decisionmaking (by Age at marriage)-Probit estimation

\begin{tabular}{|c|c|c|c|c|c|c|c|c|}
\hline VARIABLES & $\begin{array}{c}\text { Age }<18 \\
\text { Health decisions }\end{array}$ & $\begin{array}{c}\text { Age }>=18 \\
\text { Health decisions }\end{array}$ & $\begin{array}{c}\text { Age }<18 \\
\text { Social decisions }\end{array}$ & $\begin{array}{c}\text { Age }>=18 \\
\text { Social decisions }\end{array}$ & $\begin{array}{c}\text { Age }<18 \\
\text { Consumption decisions }\end{array}$ & $\begin{array}{c}\text { Age }>=18 \\
\text { Consumption decisions }\end{array}$ & $\begin{array}{c}\text { Age }<18 \\
\text { Financial decisions }\end{array}$ & $\begin{array}{c}\text { Age }>=18 \\
\text { Financial decisions }\end{array}$ \\
\hline \multicolumn{9}{|l|}{ Sons (ref: none) } \\
\hline At least one son & $0.193 * * *(0.074)$ & $0.021(0.050)$ & $0.188 * *(0.076)$ & $0.060(0.051)$ & $0.203^{* * *}(0.077)$ & $0.044(0.052)$ & $0.144 *(0.083)$ & $-0.027(0.058)$ \\
\hline Age & $0.020 * * *(0.003)$ & $0.025^{* * *}(0.003)$ & $0.024 * * *(0.003)$ & $0.025 * * *(0.003)$ & $0.026 * * *(0.003)$ & $0.024 * * *(0.003)$ & $0.009 * * *(0.003)$ & $0.009 * * *(0.003)$ \\
\hline Age difference & $0.005(0.004)$ & $0.005(0.004)$ & $0.002(0.004)$ & $0.004(0.004)$ & $-0.000(0.004)$ & $0.003(0.004)$ & $-0.004(0.004)$ & $-0.007 *(0.004)$ \\
\hline \multicolumn{9}{|c|}{ Women education (ref: none) } \\
\hline Primary & $0.130^{* *}(0.063)$ & $0.036(0.059)$ & $0.194 * * *(0.065)$ & $0.119 * *(0.060)$ & $0.089(0.065)$ & $0.028(0.060)$ & $0.058(0.068)$ & $0.125 *(0.065)$ \\
\hline Secondary & $0.353^{* * *}(0.071)$ & $0.239 * * *(0.058)$ & $0.262 * * *(0.072)$ & $0.167 * * *(0.059)$ & $0.257 * * *(0.072)$ & $0.218^{* * *}(0.059)$ & $0.243 * * *(0.076)$ & $0.196 * * *(0.064)$ \\
\hline Higher & $0.572 * * *(0.125)$ & $0.486 * * *(0.070)$ & $0.706 * * *(0.134)$ & $0.365 * * *(0.071)$ & $0.611^{* * *}(0.129)$ & $0.342 * * *(0.070)$ & $0.512 * * *(0.133)$ & $0.180 * *(0.076)$ \\
\hline \multicolumn{9}{|c|}{ Spouse education (ref: none) } \\
\hline Primary & $-0.072(0.061)$ & $-0.157 * *(0.062)$ & $0.002(0.061)$ & $-0.010(0.063)$ & $-0.012(0.062)$ & $-0.077(0.063)$ & $0.034(0.065)$ & $-0.147 * *(0.067)$ \\
\hline Secondary & $0.021(0.055)$ & $-0.023(0.052)$ & $0.084(0.055)$ & $-0.033(0.052)$ & $0.026(0.056)$ & $-0.049(0.053)$ & $0.043(0.058)$ & $-0.105 *(0.056)$ \\
\hline Higher & $-0.050(0.071)$ & $-0.005(0.061)$ & $0.124 *(0.072)$ & $0.059(0.062)$ & $0.042(0.073)$ & $0.026(0.062)$ & $-0.020(0.075)$ & $-0.053(0.067)$ \\
\hline \multicolumn{9}{|c|}{ Women employed (ref: none) } \\
\hline Yes & $0.083(0.053)$ & $0.277 * * *(0.047)$ & $0.099 *(0.053)$ & $0.262^{* * * *}(0.048)$ & $0.170^{* * *}(0.054)$ & $0.343^{* * *}(0.048)$ & $0.148 * * *(0.055)$ & $0.317 * * *(0.050)$ \\
\hline \multicolumn{9}{|c|}{ Media exposure (ref: none) } \\
\hline occasionally & $0.216^{* * *}(0.057)$ & $0.095 *(0.056)$ & $0.162 * * *(0.058)$ & $0.074(0.057)$ & $0.134^{* *}(0.059)$ & $0.051(0.058)$ & $0.149 * *(0.061)$ & $0.032(0.061)$ \\
\hline Weekly & $0.058(0.146)$ & $-0.262 * *(0.124)$ & $0.057(0.147)$ & $-0.167(0.125)$ & $0.052(0.147)$ & $-0.134(0.126)$ & $-0.021(0.148)$ & $-0.205(0.136)$ \\
\hline Daily & $0.196 * * *(0.054)$ & $0.124^{* *}(0.053)$ & $0.225^{* * *}(0.055)$ & $0.073(0.054)$ & $0.244^{* * *}(0.056)$ & $0.133^{* *}(0.054)$ & $0.134 * *(0.058)$ & $0.077(0.058)$ \\
\hline \multicolumn{9}{|c|}{ Family structure (ref: joint) } \\
\hline Nuclear family & $0.139 * *(0.060)$ & $0.264 * * *(0.049)$ & $0.376^{* * *}(0.061)$ & $0.495 * * *(0.050)$ & $0.278^{* * *}(0.063)$ & $0.487 * * *(0.050)$ & $-0.043(0.068)$ & $0.174 * * *(0.057)$ \\
\hline Household size & $-0.031^{* * *}(0.005)$ & $-0.014 * * *(0.004)$ & $-0.036^{* * *}(0.005)$ & $-0.025^{* * *}(0.004)$ & $-0.042^{* * *}(0.006)$ & $-0.027^{* * *}(0.005)$ & $-0.021^{* * *}(0.006)$ & $-0.008(0.005)$ \\
\hline \multicolumn{9}{|c|}{ Place of residence (ref: rural) } \\
\hline \multirow{2}{*}{\multicolumn{9}{|c|}{ Province/ Region (ref: Islamabad) }} \\
\hline & & & & & & & & \\
\hline Punjab & $0.379 * * *(0.108)$ & $0.261 * * *(0.067)$ & $0.379 * * *(0.111)$ & $0.066(0.069)$ & $0.246 * *(0.112)$ & $0.105(0.068)$ & $0.309 * * *(0.112)$ & $0.247 * * *(0.071)$ \\
\hline Sindh & $-0.075(0.107)$ & $0.110(0.069)$ & $-0.144(0.110)$ & $-0.105(0.071)$ & $-0.411 * * *(0.111)$ & $-0.212 * * *(0.070)$ & $-0.257 * *(0.111)$ & $-0.101(0.073)$ \\
\hline KPK & $-0.347 * * *(0.110)$ & $-0.326^{* * *}(0.075)$ & $-0.345^{* * *}(0.113)$ & $-0.508^{* * *}(0.077)$ & $-0.459 * * *(0.114)$ & $-0.403^{* * *}(0.076)$ & $-0.393^{* * * *}(0.115)$ & $-0.336^{* * * *}(0.080)$ \\
\hline Gilgit-Baltistan & $-0.217 *(0.118)$ & $0.178 *(0.097)$ & $-0.034(0.121)$ & $0.187 *(0.099)$ & $-0.511 * * *(0.122)$ & $-0.127(0.099)$ & $-0.695^{* * *}(0.123)$ & $-0.324 * * *(0.103)$ \\
\hline Balochistan & $-0.278^{* *}(0.113)$ & $-0.414 * * *(0.081)$ & $-0.240 * *(0.116)$ & $-0.594 * * *(0.083)$ & $-0.492 * * *(0.117)$ & $-0.604 * * *(0.083)$ & $-0.450 * * *(0.117)$ & $-0.562 * * *(0.087)$ \\
\hline \multicolumn{9}{|c|}{ Economic status（ref: poorest) } \\
\hline Poorer & $0.262 * * *(0.062)$ & $0.214 * * *(0.069)$ & $0.169 * * *(0.063)$ & $0.275^{* * *}(0.069)$ & $0.261^{* * *}(0.064)$ & $0.259 * * *(0.071)$ & $0.304 * * *(0.066)$ & $0.412 * * *(0.074)$ \\
\hline Middle & $0.319 * * *(0.072)$ & $0.191 * * *(0.072)$ & $0.208 * * *(0.073)$ & $0.268 * * *(0.073)$ & $0.210 * * *(0.074)$ & $0.283^{* * *}(0.074)$ & $0.331^{* * *}(0.077)$ & $0.432 * * *(0.079)$ \\
\hline Rich & $0.358 * * *(0.084)$ & $0.260 * * *(0.079)$ & $0.164 *(0.084)$ & $0.319 * * *(0.080)$ & $0.260 * * *(0.085)$ & $0.354 * * *(0.081)$ & $0.282 * * *(0.088)$ & $0.455^{* * *}(0.087)$ \\
\hline Richest & $0.266 * * *(0.099)$ & $0.147(0.091)$ & $0.221 * *(0.100)$ & $0.248 * * *(0.092)$ & $0.244 * *(0.101)$ & $0.230 * *(0.094)$ & $0.208 * *(0.104)$ & $0.398 * * *(0.100)$ \\
\hline Constant & $-1.145 * * *(0.156)$ & $-1.396 * * *(0.128)$ & $-1.358 * * *(0.160)$ & $-1.391 * * *(0.130)$ & $-1.241 * * *(0.162)$ & $-1.416 * * *(0.132)$ & $-0.459 * * *(0.169)$ & $-0.773 * * *(0.140)$ \\
\hline Observations & 4,336 & 5,681 & 4,341 & 5,694 & 4,337 & 5,689 & 3,820 & 4,712 \\
\hline
\end{tabular}

Source: Authors' calculations.

Standard errors in parentheses

${ }_{* * *} p<0.01,{ }^{* *} p<0.05,{ }^{*} p<0.1$ 
Table 10: Son preference and female participation in decisionmaking - Ordered probit estimations

\begin{tabular}{|c|c|c|c|c|}
\hline VARIABLES & Healthcare decisions & Social decisions & Consumption decisions & Financial decisions \\
\hline \multicolumn{5}{|l|}{ Sons (ref: none) } \\
\hline At least one son & $0.161 * * *(0.046)$ & $0.160 * * *(0.050)$ & $0.169 * * *(0.051)$ & $0.037(0.058)$ \\
\hline Age & $0.027 * * *(0.002)$ & $0.030 * * *(0.003)$ & $0.032 * * *(0.002)$ & $0.005^{* *}(0.003)$ \\
\hline Age difference & $0.012 * * *(0.003)$ & $0.015^{* * *}(0.003)$ & $0.012 * * *(0.003)$ & $-0.001(0.004)$ \\
\hline \multicolumn{5}{|c|}{ Women education (ref: none) } \\
\hline Primary & $0.057(0.044)$ & $0.112 * *(0.049)$ & $0.058(0.047)$ & $0.062(0.060)$ \\
\hline Secondary & $0.258 * * *(0.057)$ & $0.134 * * *(0.049)$ & $0.132 * *(0.058)$ & $0.090(0.072)$ \\
\hline Higher & $0.434 * * *(0.084)$ & $0.255^{* * *}(0.078)$ & $0.258 * * *(0.086)$ & $0.172 *(0.098)$ \\
\hline \multicolumn{5}{|c|}{ Spouse education (ref: none) } \\
\hline Primary & $-0.101^{* *}(0.051)$ & $-0.040(0.048)$ & $-0.093 *(0.050)$ & $-0.081(0.059)$ \\
\hline Secondary & $-0.043(0.043)$ & $-0.064(0.047)$ & $-0.089 *(0.046)$ & $-0.103 * *(0.049)$ \\
\hline Higher & $-0.015(0.060)$ & $-0.027(0.061)$ & $-0.034(0.062)$ & $-0.148 * *(0.064)$ \\
\hline \multicolumn{5}{|c|}{ Women employed (ref: none) } \\
\hline Yes & $0.206 * * *(0.036)$ & $0.171^{* * *}(0.031)$ & $0.216 * * *(0.039)$ & $0.160 * * *(0.043)$ \\
\hline \multicolumn{5}{|c|}{ Media exposure (ref: none) } \\
\hline Occasionally & $0.056(0.049)$ & $0.031(0.043)$ & $0.043(0.051)$ & $0.106 *(0.056)$ \\
\hline Weekly & $-0.091(0.078)$ & $-0.066(0.087)$ & $0.005(0.081)$ & $-0.099(0.121)$ \\
\hline Daily & $0.068(0.044)$ & $0.062(0.042)$ & $0.106 * *(0.044)$ & $0.121 * *(0.047)$ \\
\hline \multicolumn{5}{|c|}{ Family structure (ref: joint) } \\
\hline Nuclear family & $0.479 * * *(0.048)$ & $0.675 * * *(0.054)$ & $0.701 * * *(0.053)$ & $0.090(0.057)$ \\
\hline Household size & $-0.033^{* * *}(0.005)$ & $-0.035 * * *(0.006)$ & $-0.039 * * *(0.006)$ & $-0.016 * * *(0.005)$ \\
\hline \multicolumn{5}{|c|}{ Place of residence (ref: rural) } \\
\hline Urban & $0.238 * * *(0.054)$ & $0.181^{* * *}(0.048)$ & $0.185 * * *(0.048)$ & $0.171^{* * *}(0.061)$ \\
\hline \multicolumn{5}{|c|}{ Province/ Region (ref: Islamabad) } \\
\hline Punjab & $0.131 * *(0.063)$ & $0.044(0.058)$ & $0.069(0.060)$ & $0.170 * *(0.071)$ \\
\hline Sindh & $-0.034(0.070)$ & $-0.102(0.065)$ & $-0.231 * * *(0.067)$ & $-0.146 *(0.078)$ \\
\hline KPK region & $-0.275^{* * *}(0.070)$ & $-0.336 * * *(0.064)$ & $-0.321 * * *(0.068)$ & $-0.274 * * *(0.084)$ \\
\hline Gilgit-Baltistan & $-0.093(0.116)$ & $-0.080(0.122)$ & $-0.375^{* * *}(0.080)$ & $-0.762 * * *(0.109)$ \\
\hline Balochistan & $-0.230 * * *(0.083)$ & $-0.209 * *(0.082)$ & $-0.238 * * *(0.083)$ & $-0.501 * * *(0.098)$ \\
\hline \multicolumn{5}{|c|}{ Economic status (ref: poorest) } \\
\hline Poorer & $0.111 * *(0.052)$ & $0.120 * *(0.047)$ & $0.107 * *(0.046)$ & $0.266 * * *(0.053)$ \\
\hline Middle & $0.046(0.070)$ & $0.063(0.059)$ & $0.045(0.056)$ & $0.276 * * *(0.073)$ \\
\hline Rich & $-0.003(0.080)$ & $-0.009(0.066)$ & $-0.011(0.064)$ & $0.215^{* *}(0.084)$ \\
\hline Richest & $-0.016(0.091)$ & $-0.015(0.078)$ & $-0.063(0.076)$ & $0.206 * *(0.104)$ \\
\hline \multicolumn{5}{|l|}{ Marginal effect } \\
\hline Family elders & $-0.028 * * *(0.008)$ & $-0.034 * * *(0.011)$ & $-0.036 * * *(0.011)$ & $-0.001(0.002)$ \\
\hline Husband alone & $-0.027 * * *(0.007)$ & $-0.019 * * *(0.005)$ & $-0.020 * * *(0.005)$ & $-0.012(0.019)$ \\
\hline Joint & $0.033^{* * *}(0.010)$ & $0.035^{* * *}(0.011)$ & $0.037 * * *(0.012)$ & $0.009(0.014)$ \\
\hline Respondent alone & $0.022 * * *(0.006)$ & $0.019 * * *(0.005)$ & $0.018 * * *(0.005)$ & $0.004(0.007)$ \\
\hline Constant cut1 & $0.063(0.111)$ & $0.423 * * *(0.107)$ & $0.456 * * *(0.118)$ & $-1.838 * * *(0.134)$ \\
\hline Constant cut2 & $1.326 * * *(0.111)$ & $1.478 * * *(0.109)$ & $1.609 * * *(0.118)$ & $0.302 * *(0.129)$ \\
\hline Constant cut3 & $2.929 * * *(0.118)$ & $3.206 * * *(0.118)$ & $3.326 * * *(0.128)$ & $2.045 * * *(0.130)$ \\
\hline Observations & 10,017 & 10,035 & 10,026 & 8,532 \\
\hline
\end{tabular}

Source: Authors' calculations.

Standard errors in parentheses

*** $\mathrm{p}<0.01$, ** $\mathrm{p}<0.05$, * $\mathrm{p}<0.1$ 
Table 11: Number of sons and female participation in decision making - Ordered probit estimations

\begin{tabular}{|c|c|c|c|c|}
\hline VARIABLES & Healthcare decisions & Social decisions & Consumption decisions & Financial decisions \\
\hline \multicolumn{5}{|l|}{ Sons (ref: 0) } \\
\hline 1 & $0.122 * *(0.052)$ & $0.107 *(0.055)$ & $0.114 * *(0.056)$ & $0.031(0.062)$ \\
\hline 2 & $0.194 * * *(0.050)$ & $0.205^{* * *}(0.056)$ & $0.216 * * *(0.057)$ & $0.051(0.066)$ \\
\hline 3 & $0.231 * * *(0.052)$ & $0.237 * * *(0.064)$ & $0.263^{* * *}(0.059)$ & $0.029(0.076)$ \\
\hline $3+$ & $0.173 * * *(0.059)$ & $0.204 * * *(0.062)$ & $0.185^{* * *}(0.067)$ & $0.024(0.077)$ \\
\hline Age & $0.025 * * *(0.002)$ & $0.028 * * *(0.003)$ & $0.030 * * *(0.002)$ & $0.005 *(0.003)$ \\
\hline Age difference & $0.012 * * *(0.003)$ & $0.015^{* * *}(0.003)$ & $0.012 * * *(0.003)$ & $-0.001(0.004)$ \\
\hline \multicolumn{5}{|c|}{ Women education (ref: none) } \\
\hline Primary & $0.058(0.044)$ & $0.113 * *(0.049)$ & $0.059(0.047)$ & $0.061(0.060)$ \\
\hline Secondary & $0.262 * * *(0.057)$ & $0.140 * * *(0.049)$ & $0.139 * *(0.059)$ & $0.090(0.072)$ \\
\hline Higher & $0.444 * * *(0.084)$ & $0.270 * * *(0.077)$ & $0.272 * * *(0.086)$ & $0.173 *(0.097)$ \\
\hline \multicolumn{5}{|c|}{ Spouse education (ref: none) } \\
\hline Primary & $-0.099 *(0.051)$ & $-0.038(0.047)$ & $-0.091 *(0.051)$ & $-0.081(0.059)$ \\
\hline Secondary & $-0.041(0.043)$ & $-0.061(0.047)$ & $-0.086 *(0.046)$ & $-0.104 * *(0.050)$ \\
\hline Higher & $-0.013(0.060)$ & $-0.024(0.061)$ & $-0.031(0.062)$ & $-0.150 * *(0.064)$ \\
\hline \multicolumn{5}{|c|}{ Women employed (ref: none) } \\
\hline Yes & $0.204 * * *(0.036)$ & $0.169 * * *(0.031)$ & $0.213^{* * *}(0.038)$ & $0.160 * * *(0.043)$ \\
\hline \multicolumn{5}{|c|}{ Media exposure (ref: none) } \\
\hline Occasionally & $0.055(0.049)$ & $0.029(0.044)$ & $0.041(0.051)$ & $0.105 *(0.056)$ \\
\hline Weekly & $-0.094(0.078)$ & $-0.070(0.086)$ & $0.001(0.080)$ & $-0.098(0.120)$ \\
\hline Daily & $0.068(0.044)$ & $0.061(0.042)$ & $0.105^{* *}(0.045)$ & $0.121^{* *}(0.047)$ \\
\hline \multicolumn{5}{|c|}{ Family structure (ref: joint) } \\
\hline Nuclear family & $0.466 * * *(0.049)$ & $0.657 * * *(0.056)$ & $0.684 * * *(0.055)$ & $0.091(0.059)$ \\
\hline Household size & $-0.034 * * *(0.006)$ & $-0.037 * * *(0.006)$ & $-0.040 * * *(0.006)$ & $-0.016^{* * *}(0.006)$ \\
\hline \multicolumn{5}{|c|}{ Place of residence (ref: rural) } \\
\hline Urban & $0.237 * * *(0.054)$ & $0.181^{* * *}(0.048)$ & $0.185^{* * *}(0.048)$ & $0.170 * * *(0.061)$ \\
\hline \multicolumn{5}{|c|}{ Province/ Region (ref: Islamabad) } \\
\hline Punjab & $0.131^{* *}(0.063)$ & $0.042(0.058)$ & $0.067(0.061)$ & $0.170 * *(0.071)$ \\
\hline Sindh & $-0.033(0.070)$ & $-0.102(0.066)$ & $-0.230 * * *(0.067)$ & $-0.146 *(0.078)$ \\
\hline KPK & $-0.279 * * *(0.070)$ & $-0.342 * * *(0.065)$ & $-0.327 * * *(0.068)$ & $-0.274 * * *(0.084)$ \\
\hline Gilgit-Baltistan & $-0.101(0.115)$ & $-0.092(0.122)$ & $-0.387 * * *(0.081)$ & $-0.762 * * *(0.109)$ \\
\hline Balochistan & $-0.233^{* * *}(0.083)$ & $-0.213^{* *}(0.083)$ & $-0.242 * * *(0.083)$ & $-0.501^{* * *}(0.098)$ \\
\hline \multicolumn{5}{|c|}{ Economic status (ref: poorest) } \\
\hline Poorer & $0.108^{* *}(0.052)$ & $0.117^{* *}(0.047)$ & $0.103^{* *}(0.045)$ & $0.266 * * *(0.053)$ \\
\hline Middle & $0.043(0.070)$ & $0.061(0.059)$ & $0.041(0.056)$ & $0.276 * * *(0.072)$ \\
\hline Rich & $-0.004(0.081)$ & $-0.008(0.066)$ & $-0.012(0.064)$ & $0.214 * *(0.085)$ \\
\hline Richest & $-0.016(0.092)$ & $-0.011(0.078)$ & $-0.062(0.076)$ & $0.205 *(0.105)$ \\
\hline Constant cut 1 & $0.013(0.118)$ & $0.346^{* * *}(0.117)$ & $0.387^{* * *}(0.126)$ & $-1.833 * * *(0.142)$ \\
\hline Constant cut 2 & $1.277^{* * *}(0.118)$ & $1.402 * * *(0.118)$ & $1.541 * * *(0.125)$ & $0.308^{* *}(0.138)$ \\
\hline Constant cut 3 & $2.880 * * *(0.124)$ & $3.131 * * *(0.127)$ & $3.260 * * *(0.134)$ & $2.051 * * *(0.141)$ \\
\hline Observations & 10,017 & 10,035 & 10,026 & 8,532 \\
\hline
\end{tabular}

Source: Authors' calculations.

Standard errors in parentheses

*** $\mathrm{p}<0.01,{ }^{* *} \mathrm{p}<0.05,{ }^{*} \mathrm{p}<0.1$ 
Table 12: Son preference and female participation in decisionmaking (parity wise) - Ordered probit estimations

\begin{tabular}{|c|c|c|c|c|c|c|c|c|}
\hline \multirow[t]{2}{*}{ VARIABLES } & \multicolumn{2}{|c|}{ Healthcare decisions } & \multicolumn{2}{|c|}{ Social decisions } & \multicolumn{2}{|c|}{ Consumption decisions } & \multicolumn{2}{|c|}{ Financial decisions } \\
\hline & (Parity $\leq 3)$ & (Parity $>3)$ & (Parity $\leq 3)$ & (Parity $>3)$ & (Parity $\leq 3)$ & (Parity $>3)$ & $($ Parity $\leq 3)$ & (Parity> 3) \\
\hline \multicolumn{9}{|l|}{ Sons (ref: none) } \\
\hline At least one son & $0.155^{* * *}(0.048)$ & $0.020(0.183)$ & $0.154 * * *(0.053)$ & $-0.014(0.181)$ & $0.134 * * *(0.051)$ & $0.122(0.139)$ & $0.010(0.064)$ & $0.124(0.185)$ \\
\hline Age & $0.029 * * *(0.003)$ & $0.019 * * *(0.003)$ & $0.032 * * *(0.003)$ & $0.023 * * *(0.004)$ & $0.036 * * *(0.003)$ & $0.022 * * *(0.004)$ & $0.009 * *(0.004)$ & $-0.000(0.004)$ \\
\hline Age difference & $0.022 * * *(0.004)$ & $0.003(0.004)$ & $0.025 * * *(0.004)$ & $0.007 *(0.004)$ & $0.020 * * *(0.004)$ & $0.005(0.004)$ & $-0.001(0.005)$ & $-0.000(0.005)$ \\
\hline \multicolumn{9}{|c|}{ Women education (ref: none) } \\
\hline Primary & $0.064(0.060)$ & $0.083(0.060)$ & $0.039(0.067)$ & $0.232 * * *(0.067)$ & $0.036(0.067)$ & $0.111(0.068)$ & $0.002(0.104)$ & $0.120 *(0.072)$ \\
\hline Secondary & $0.332 * * *(0.074)$ & $0.212 * *(0.094)$ & $0.215^{* * *}(0.066)$ & $0.051(0.082)$ & $0.193 * * *(0.069)$ & $0.106(0.090)$ & $0.147 *(0.083)$ & $0.022(0.099)$ \\
\hline Higher & $0.616 * * *(0.087)$ & $0.050(0.162)$ & $0.327 * * *(0.080)$ & $0.169(0.146)$ & $0.343^{* * * *}(0.091)$ & $0.172(0.184)$ & $0.176(0.115)$ & $0.242(0.186)$ \\
\hline \multicolumn{9}{|c|}{ Spouse education (ref: none) } \\
\hline Primary & $-0.038(0.072)$ & $-0.142 * *(0.065)$ & $-0.000(0.070)$ & $-0.061(0.060)$ & $-0.040(0.074)$ & $-0.128 * *(0.060)$ & $-0.052(0.082)$ & $-0.104(0.071)$ \\
\hline Secondary & $-0.023(0.060)$ & $-0.068(0.062)$ & $-0.080(0.067)$ & $-0.062(0.059)$ & $-0.070(0.064)$ & $-0.112 *(0.061)$ & $-0.160 * *(0.064)$ & $-0.066(0.062)$ \\
\hline Higher & $0.003(0.076)$ & $-0.063(0.087)$ & $-0.011(0.080)$ & $-0.087(0.096)$ & $0.023(0.083)$ & $-0.126(0.100)$ & $-0.205 * *(0.084)$ & $-0.117(0.093)$ \\
\hline \multicolumn{9}{|c|}{ Women employed (ref: none) } \\
\hline Yes & $0.179 * * *(0.058)$ & $0.212 * * *(0.043)$ & $0.144 * * *(0.054)$ & $0.178 * * *(0.051)$ & $0.185^{* * *}(0.058)$ & $0.222 * * *(0.048)$ & $0.159 * *(0.067)$ & $0.161^{* * *}(0.057)$ \\
\hline \multicolumn{9}{|c|}{ Media exposure (ref: none) } \\
\hline Occasionally & $0.105(0.068)$ & $0.023(0.071)$ & $0.104(0.065)$ & $-0.021(0.068)$ & $0.042(0.067)$ & $0.049(0.085)$ & $0.205^{* *}(0.092)$ & $0.035(0.072)$ \\
\hline Weekly & $-0.133(0.132)$ & $-0.043(0.120)$ & $-0.243^{* *}(0.122)$ & $0.121(0.125)$ & $-0.137(0.125)$ & $0.142(0.124)$ & $-0.351 *(0.191)$ & $0.080(0.140)$ \\
\hline Daily & $0.047(0.061)$ & $0.100(0.061)$ & $0.063(0.064)$ & $0.075(0.063)$ & $0.063(0.061)$ & $0.154^{* *}(0.066)$ & $0.134 *(0.074)$ & $0.115 *(0.064)$ \\
\hline \multicolumn{9}{|c|}{ Family structure (ref: joint) } \\
\hline Nuclear family & $0.486^{* * *}(0.065)$ & $0.354 * * *(0.073)$ & $0.675^{* * *}(0.069)$ & $0.574 * * *(0.081)$ & $0.671^{* * *}(0.060)$ & $0.589 * * *(0.084)$ & $0.075(0.084)$ & $0.094(0.098)$ \\
\hline Household size & $-0.032^{* * *}(0.008)$ & $-0.039^{* * *}(0.007)$ & $-0.035^{* * *}(0.008)$ & $-0.037^{* * *}(0.006)$ & $-0.043^{* * *}(0.008)$ & $-0.040^{* * *}(0.007)$ & $-0.014(0.008)$ & $-0.019 * * *(0.007)$ \\
\hline \multicolumn{9}{|c|}{ Place of residence (ref: rural) } \\
\hline Urban & $0.190 * * *(0.072)$ & $0.281 * * *(0.072)$ & $0.183^{* * *}(0.061)$ & $0.181^{* *}(0.071)$ & $0.200^{* * *}(0.061)$ & $0.171^{* *}(0.072)$ & $0.180 * *(0.080)$ & $0.158^{* *}(0.075)$ \\
\hline \multicolumn{9}{|c|}{ Province/ Region (ref: Islamabad) } \\
\hline Punjab & $0.127(0.087)$ & $0.119(0.084)$ & $0.067(0.071)$ & $-0.004(0.096)$ & $0.099(0.071)$ & $0.009(0.108)$ & $0.211^{* *}(0.087)$ & $0.121(0.112)$ \\
\hline Sindh & $0.039(0.091)$ & $-0.124(0.095)$ & $-0.017(0.078)$ & $-0.209 * *(0.103)$ & $-0.122(0.079)$ & $-0.372 * * *(0.112)$ & $-0.087(0.095)$ & $-0.204 *(0.116)$ \\
\hline KPK region & $-0.259 * * *(0.100)$ & $-0.311^{* * *}(0.096)$ & $-0.274 * * *(0.083)$ & $-0.420 * * *(0.106)$ & $-0.243 * * *(0.086)$ & $-0.423 * * *(0.118)$ & $-0.338 * * *(0.112)$ & $-0.258 * *(0.122)$ \\
\hline Gilgit-Baltistan & $0.081(0.147)$ & $-0.245 *(0.144)$ & $0.197(0.140)$ & $-0.312 *(0.161)$ & $-0.210 * *(0.096)$ & $-0.539 * * *(0.134)$ & $-0.825 * * *(0.134)$ & $-0.747 * * *(0.149)$ \\
\hline Balochistan & $0.002(0.103)$ & $-0.474 * * *(0.108)$ & $0.122(0.099)$ & $-0.554 * * *(0.114)$ & $0.107(0.096)$ & $-0.610 * * *(0.125)$ & $-0.379 * * *(0.128)$ & $-0.602 * * *(0.128)$ \\
\hline \multicolumn{9}{|c|}{ Economic status (ref: poorest) } \\
\hline Poorer & $0.076(0.075)$ & $0.143^{* *}(0.069)$ & $0.101(0.070)$ & $0.134^{* *}(0.063)$ & $0.040(0.073)$ & $0.169 * * *(0.061)$ & $0.294^{* * *}(0.090)$ & $0.252^{* * *}(0.074)$ \\
\hline Middle & $-0.026(0.088)$ & $0.115(0.099)$ & $0.043(0.083)$ & $0.095(0.080)$ & $-0.036(0.082)$ & $0.125 *(0.074)$ & $0.237 * *(0.104)$ & $0.323 * * *(0.098)$ \\
\hline Rich & $-0.060(0.097)$ & $0.056(0.123)$ & $-0.084(0.093)$ & $0.071(0.097)$ & $-0.116(0.092)$ & $0.095(0.093)$ & $0.218 *(0.119)$ & $0.226 * *(0.112)$ \\
\hline Richest & $-0.062(0.121)$ & $0.035(0.136)$ & $-0.076(0.109)$ & $0.054(0.111)$ & $-0.201 *(0.108)$ & $0.089(0.108)$ & $0.194(0.147)$ & $0.248 * *(0.125)$ \\
\hline Constant cut1 & $0.360 * *(0.164)$ & $-0.868^{* * *}(0.230)$ & $0.718^{* * *}(0.155)$ & $-0.465^{* *}(0.220)$ & $0.700^{* * *}(0.157)$ & $-0.461 * *(0.222)$ & $-1.763^{* * *}(0.204)$ & $-1.979 * * *(0.251)$ \\
\hline Constant cut 2 & $1.440 * * *(0.167)$ & $0.699 * * *(0.233)$ & $1.598 * * *(0.161)$ & $0.856^{* * *}(0.228)$ & $1.632^{* * *}(0.162)$ & $1.023^{* * *}(0.223)$ & $0.470 * *(0.200)$ & $0.111(0.257)$ \\
\hline Constant cut 3 & $3.063 * * *(0.175)$ & $2.298 * * *(0.235)$ & $3.294 * * *(0.173)$ & $2.622 * * *(0.234)$ & $3.405 * * *(0.172)$ & $2.711 * * *(0.234)$ & $2.233 * * *(0.205)$ & $1.849 * * *(0.256)$ \\
\hline Observations & 4,906 & 5,111 & 4,909 & 5,126 & 4,908 & 5,118 & 3,789 & 4,743 \\
\hline
\end{tabular}

Source: Authors' calculations.

Standard errors in parentheses 
Table 13: Son preference and female participation in decisionmaking (by pregnancy loss) probit estimation

\begin{tabular}{|c|c|c|c|c|c|}
\hline VARIABLES & $\begin{array}{l}\text { Healthcare } \\
\text { decisions }\end{array}$ & Social decisions & $\begin{array}{c}\text { Consumption } \\
\text { decisions }\end{array}$ & Financial decisions & All decisions \\
\hline At least one son & $0.207 * *(0.084)$ & $0.383 * * *(0.086)$ & $0.333 * * *(0.085)$ & $0.106(0.098)$ & $0.357 * * *(0.113)$ \\
\hline Age difference & $0.002(0.006)$ & $0.008(0.006)$ & $0.002(0.006)$ & $-0.000(0.006)$ & $-0.005(0.006)$ \\
\hline \multicolumn{6}{|c|}{ Education (ref: none) } \\
\hline Primary & $0.124(0.089)$ & $0.223^{* *}(0.091)$ & $0.076(0.088)$ & $0.116(0.097)$ & $0.195 *(0.104)$ \\
\hline \multicolumn{6}{|c|}{ Spouse education (ref: none) } \\
\hline Primary & $-0.026(0.085)$ & $-0.012(0.085)$ & $-0.075(0.086)$ & $-0.076(0.091)$ & $-0.014(0.094)$ \\
\hline Secondary & $0.040(0.082)$ & $0.003(0.081)$ & $-0.067(0.083)$ & $-0.093(0.087)$ & $-0.036(0.090)$ \\
\hline Higher & $0.119(0.108)$ & $0.081(0.110)$ & $0.037(0.112)$ & $-0.002(0.111)$ & $0.104(0.117)$ \\
\hline \multicolumn{6}{|c|}{ Employed (ref: none) } \\
\hline Yes & $0.275^{* * *}(0.070)$ & $0.244 * * *(0.068)$ & $0.291 * * *(0.068)$ & $0.189 * *(0.074)$ & $0.379 * * *(0.077)$ \\
\hline \multicolumn{6}{|c|}{ Family structure (ref: joint) } \\
\hline Nuclear family & $0.289 * * *(0.086)$ & $0.459 * * *(0.086)$ & $0.473 * * *(0.087)$ & $0.150(0.100)$ & $0.001(0.111)$ \\
\hline Household size & $-0.034 * * *(0.008)$ & $-0.043^{* * *}(0.009)$ & $-0.042 * * *(0.009)$ & $-0.012(0.009)$ & $-0.041^{* * *}(0.009)$ \\
\hline \multicolumn{6}{|c|}{ Place of residence (ref: rural) } \\
\hline Urban & $0.101(0.078)$ & $0.166^{* *}(0.078)$ & $0.162 * *(0.078)$ & $0.032(0.082)$ & $0.087(0.092)$ \\
\hline \multicolumn{6}{|c|}{ Province/ Region (ref: Islamabad) } \\
\hline Punjab & $0.391 * * *(0.103)$ & $0.262 * *(0.103)$ & $0.227 * *(0.104)$ & $0.373 * * *(0.105)$ & $0.297 * *(0.134)$ \\
\hline Sindh & $0.136(0.105)$ & $-0.112(0.104)$ & $-0.207 * *(0.106)$ & $-0.001(0.106)$ & $-0.322 * *(0.128)$ \\
\hline KPK & $-0.155(0.114)$ & $-0.324 * * *(0.113)$ & $-0.346 * * *(0.115)$ & $-0.210 *(0.118)$ & $-0.376 * * *(0.139)$ \\
\hline Gilgit-Baltistan & $-0.097(0.144)$ & $-0.177(0.145)$ & $-0.414 * * *(0.143)$ & $-0.593 * * *(0.147)$ & $-0.454 * * *(0.163)$ \\
\hline Balochistan & $-0.457 * * *(0.130)$ & $-0.720 * * *(0.131)$ & $-0.686 * * *(0.134)$ & $-0.653 * * *(0.132)$ & $-1.024 * * *(0.149)$ \\
\hline
\end{tabular}

Source: Authors' calculations.

Standard errors in parentheses

${ }^{* * *} \mathrm{p}<0.01,{ }^{* *} \mathrm{p}<0.05,{ }^{*} \mathrm{p}<0.1$ 
Table 14: Selection Bias: Younger women (Aged 25 or less) and women with schooling - Probit estimates

\begin{tabular}{|c|c|c|c|c|c|c|c|c|c|c|}
\hline \multirow[b]{2}{*}{ VARIABLES } & \multicolumn{5}{|c|}{$\begin{array}{c}\text { Younger Women }(\text { Age }<=25) \\
\end{array}$} & \multicolumn{5}{|c|}{ Have schooling } \\
\hline & $\begin{array}{c}\text { Healthcare } \\
\text { decisions }\end{array}$ & Social decisions & $\begin{array}{c}\text { Consumption } \\
\text { decisions }\end{array}$ & Financial decisions & All decisions & $\begin{array}{c}\text { Healthcare } \\
\text { decisions }\end{array}$ & Social decisions & $\begin{array}{c}\text { Consumption } \\
\text { decisions }\end{array}$ & $\begin{array}{l}\text { Financial } \\
\text { decisions }\end{array}$ & All decisions \\
\hline \multicolumn{11}{|l|}{ Sons (ref: none) } \\
\hline At least one son & $0.249 * * *(0.072)$ & $0.332 * * *(0.073)$ & $0.294^{* * *}(0.076)$ & $0.075(0.089)$ & $0.174 *(0.091)$ & $0.223 * * *(0.063)$ & $0.324 * * *(0.065)$ & $0.264 * * *(0.064)$ & $0.104(0.074)$ & $0.258 * * *(0.088)$ \\
\hline Age & & & & & & $0.030^{* * *}(0.004)$ & $0.033^{* * *}(0.004)$ & $0.033^{* * *}(0.004)$ & $0.010^{* *}(0.004)$ & $0.020 * * *(0.006)$ \\
\hline Age difference & $0.011(0.007)$ & $0.027 * * *(0.007)$ & $0.024 * * *(0.007)$ & $-0.001(0.008)$ & $0.001(0.009)$ & $0.007(0.006)$ & $0.015 * *(0.006)$ & $0.011 *(0.006)$ & $-0.013 * *(0.006)$ & $-0.003(0.007)$ \\
\hline \multicolumn{11}{|c|}{ Education (ref: none) } \\
\hline Primary & $-0.072(0.101)$ & $0.049(0.105)$ & $0.062(0.108)$ & $-0.071(0.133)$ & $-0.090(0.142)$ & & & & & \\
\hline Secondary & $0.113(0.108)$ & $0.058(0.110)$ & $-0.039(0.118)$ & $-0.116(0.142)$ & $0.015(0.154)$ & & & & & \\
\hline Higher & $0.313 * *(0.151)$ & $0.262^{*}(0.159)$ & $0.327 * *(0.164)$ & $0.305(0.221)$ & $0.704 * * *(0.219)$ & & & & & \\
\hline \multicolumn{11}{|c|}{ Spouse education (ref: none) } \\
\hline Primary & $-0.147(0.110)$ & $-0.103(0.105)$ & $-0.138(0.110)$ & $-0.096(0.134)$ & $-0.222(0.137)$ & $-0.135(0.106)$ & $0.075(0.108)$ & $-0.037(0.110)$ & $-0.065(0.121)$ & $-0.140(0.140)$ \\
\hline Secondary & $0.031(0.100)$ & $-0.099(0.106)$ & $-0.084(0.112)$ & $-0.160(0.123)$ & $-0.157(0.126)$ & $0.014(0.095)$ & $-0.003(0.097)$ & $0.025(0.098)$ & $-0.105(0.105)$ & $-0.145(0.126)$ \\
\hline Higher & $0.091(0.126)$ & $0.038(0.129)$ & $0.128(0.134)$ & $-0.311 *(0.162)$ & $-0.030(0.169)$ & $0.118(0.100)$ & $0.156(0.102)$ & $0.180 *(0.103)$ & $-0.021(0.109)$ & $0.039(0.135)$ \\
\hline \multicolumn{11}{|c|}{ Employed (ref: none) } \\
\hline Yes & $0.128(0.102)$ & $0.053(0.104)$ & $0.036(0.110)$ & $0.301 * *(0.127)$ & $0.199(0.131)$ & $0.255^{* * *}(0.077)$ & $0.384 * * *(0.075)$ & $0.370 * * *(0.076)$ & $0.214 * * *(0.080)$ & $0.406 * * *(0.103)$ \\
\hline \multicolumn{11}{|c|}{ Media exposure (ref: none) } \\
\hline Occasionally & $0.047(0.109)$ & $0.039(0.111)$ & $0.036(0.115)$ & $0.128(0.133)$ & $0.227(0.139)$ & $0.091(0.100)$ & $0.211^{* *}(0.102)$ & $0.176 *(0.103)$ & $0.007(0.112)$ & $0.167(0.132)$ \\
\hline Weekly & $-0.070(0.232)$ & $-0.463 *(0.244)$ & $0.149(0.230)$ & $0.085(0.308)$ & $0.111(0.280)$ & $0.133(0.175)$ & $0.150(0.173)$ & $0.390 * *(0.171)$ & $-0.244(0.199)$ & $0.066(0.209)$ \\
\hline Daily & $0.048(0.098)$ & $0.065(0.100)$ & $0.042(0.104)$ & $0.069(0.124)$ & $0.219 *(0.130)$ & $0.209 * *(0.088)$ & $0.246 * * *(0.090)$ & $0.291^{* * * *}(0.090)$ & $0.147(0.100)$ & $0.336^{* * *}(0.117)$ \\
\hline \multicolumn{11}{|c|}{ Family structure (ref: joint) } \\
\hline Nuclear family & $0.428 * * *(0.089)$ & $0.610^{* * *}(0.092)$ & $0.496 * * *(0.095)$ & $0.018(0.114)$ & $-0.009(0.120)$ & $0.326 * * *(0.072)$ & $0.520 * * *(0.073)$ & $0.484 * * *(0.072)$ & $0.210 * *(0.086)$ & $-0.027(0.103)$ \\
\hline Household size & $-0.009(0.008)$ & $-0.025 * * *(0.009)$ & $-0.037 * * *(0.010)$ & $-0.002(0.010)$ & $-0.011(0.011)$ & $-0.032 * * *(0.007)$ & $-0.035^{* * *}(0.008)$ & $-0.042^{* * *}(0.008)$ & $-0.011(0.009)$ & $-0.036^{* * *}(0.010)$ \\
\hline \multicolumn{11}{|c|}{ Place of residence (ref: rural) } \\
\hline Urban & $0.179 *(0.092)$ & $0.069(0.097)$ & $0.251 * *(0.100)$ & $0.153(0.124)$ & $0.159(0.125)$ & $0.191^{* * *}(0.068)$ & $0.131 *(0.069)$ & $0.130 *(0.068)$ & $0.008(0.077)$ & $0.084(0.092)$ \\
\hline \multicolumn{11}{|c|}{ Province/ Region (ref: Islamabad) } \\
\hline Punjab & $-0.055(0.141)$ & $-0.049(0.144)$ & $-0.073(0.147)$ & $0.286(0.177)$ & $0.225(0.191)$ & $0.148 * *(0.071)$ & $0.034(0.072)$ & $0.001(0.072)$ & $0.151^{* *}(0.074)$ & $0.096(0.095)$ \\
\hline Sindh & $-0.032(0.147)$ & $-0.177(0.149)$ & $-0.365^{* *}(0.153)$ & $-0.099(0.184)$ & $-0.127(0.196)$ & $0.215^{* * *}(0.074)$ & $-0.008(0.075)$ & $-0.120(0.074)$ & $-0.030(0.076)$ & $-0.089(0.098)$ \\
\hline KPK & $-0.930 * * *(0.157)$ & $-0.747 * * *(0.161)$ & $-0.797 * * *(0.164)$ & $-0.550^{* * *}(0.196)$ & $-0.730^{* * *}(0.204)$ & $-0.429 * * *(0.089)$ & $-0.561^{* * *}(0.091)$ & $-0.480^{* * *}(0.091)$ & $-0.254 * *(0.098)$ & $-0.571^{* * *}(0.112)$ \\
\hline Gilgit-Baltistan & $-0.266(0.180)$ & $0.021(0.185)$ & $-0.612 * * *(0.189)$ & $-0.906 * * *(0.227)$ & $-0.575^{* *}(0.236)$ & $0.224 *(0.124)$ & $0.308 * *(0.128)$ & $-0.153(0.118)$ & $-0.379 * * *(0.128)$ & $0.030(0.160)$ \\
\hline Balochistan & $-0.488^{* * *}(0.168)$ & $-0.223(0.171)$ & $-0.321 *(0.176)$ & $-0.513 * *(0.201)$ & $-0.807 * * *(0.212)$ & $-0.221 *(0.125)$ & $-0.204(0.131)$ & $-0.341^{* * *}(0.132)$ & $-0.382 * * *(0.128)$ & $-0.770^{* * *}(0.146)$ \\
\hline \multicolumn{11}{|c|}{ Economic status（ref: poorest) } \\
\hline Poorer & $0.307 * *(0.125)$ & $0.272 * *(0.126)$ & $0.199(0.129)$ & $0.506 * * *(0.148)$ & $0.378^{* *}(0.150)$ & $0.164(0.184)$ & $0.295(0.192)$ & $0.120(0.192)$ & $0.509 * *(0.214)$ & $0.085(0.259)$ \\
\hline Middle & $0.368 * * *(0.138)$ & $0.347 * *(0.140)$ & $0.213(0.146)$ & $0.369 * *(0.170)$ & $0.410 * *(0.176)$ & $0.120(0.179)$ & $0.149(0.187)$ & $0.045(0.188)$ & $0.510 * *(0.207)$ & $0.263(0.254)$ \\
\hline Rich & $0.144(0.156)$ & $0.240(0.164)$ & $0.046(0.168)$ & $0.380 *(0.205)$ & $0.228(0.217)$ & $0.043(0.179)$ & $0.132(0.189)$ & $-0.037(0.189)$ & $0.441^{* *}(0.208)$ & $0.249(0.258)$ \\
\hline Richest & $-0.058(0.183)$ & $0.180(0.189)$ & $-0.009(0.197)$ & $0.265(0.253)$ & $0.190(0.267)$ & $0.023(0.189)$ & $0.194(0.197)$ & $-0.026(0.197)$ & $0.469 * *(0.217)$ & $0.310(0.270)$ \\
\hline Marginal Effect & $0.084^{* * *}(0.024)$ & $0.101^{* * *}(0.022)$ & $0.085 * * *(0.021)$ & $0.027(0.032)$ & $0.055 *(0.029)$ & $0.077 * * *(0.022)$ & $0.106^{* * *}(0.021)$ & $0.088^{* * *}(0.021)$ & $0.038(0.027)$ & $0.062 * * *(0.022)$ \\
\hline Constant & $-0.763 * * *(0.199)$ & $-0.956 * * *(0.209)$ & $-0.745 * * *(0.214)$ & $-0.350(0.247)$ & $0.117(0.254)$ & $-1.360 * * *(0.226)$ & $-1.758^{* * *}(0.234)$ & $-1.549 * * *(0.235)$ & $-0.690 * * *(0.253)$ & $-0.062(0.313)$ \\
\hline Observations & 2,769 & 2,768 & 2,767 & 1,683 & 1,679 & 4,967 & 4,971 & 4,974 & 3,877 & 3,863 \\
\hline
\end{tabular}

Source: Authors' calculations.

Standard errors in parentheses

*** $\mathrm{p}<0.01, * * \mathrm{p}<0.05,{ }^{*} \mathrm{p}<0.1$ 
Table 15: Selection bias: Household wealth and sex of firstborn - Probit estimates

\begin{tabular}{|c|c|c|c|c|c|c|c|c|c|c|}
\hline \multirow[b]{2}{*}{ VARIABLES } & \multicolumn{5}{|c|}{ Sex of firstborn } & \multicolumn{5}{|c|}{ Wealth (Above median) } \\
\hline & $\begin{array}{c}\text { Healthcare } \\
\text { decisions }\end{array}$ & Social decisions & $\begin{array}{c}\begin{array}{c}\text { Consumption } \\
\text { decisions }\end{array} \\
\end{array}$ & $\begin{array}{l}\text { Financial } \\
\text { decisions }\end{array}$ & All decisions & $\begin{array}{c}\text { Healthcare } \\
\text { decisions }\end{array}$ & Social decisions & $\begin{array}{c}\text { Consumption } \\
\text { decisions }\end{array}$ & $\begin{array}{l}\text { Financial } \\
\text { decisions }\end{array}$ & All decisions \\
\hline \multicolumn{11}{|c|}{ Sex of firstborn (ref: Female) } \\
\hline Male & $0.168^{* *}(0.074)$ & $0.164^{* *}(0.077)$ & $0.191^{* *}(0.079)$ & $0.184^{* *}(0.091)$ & $0.196 * *(0.095)$ & & & & & \\
\hline \multicolumn{11}{|l|}{ Sons (ref: none) } \\
\hline At least one son & & & & & & $0.296 * * *(0.066)$ & $0.280 * * *(0.070)$ & $0.219 * * *(0.068)$ & $0.066(0.079)$ & $0.223 * *(0.093)$ \\
\hline Age & $0.030 * * *(0.005)$ & $0.032 * * *(0.006)$ & $0.033 * * *(0.006)$ & $0.006(0.006)$ & $0.011 *(0.006)$ & $0.028 * * *(0.004)$ & $0.032 * * *(0.004)$ & $0.033 * * *(0.004)$ & $0.010 * *(0.004)$ & $0.022 * * *(0.005)$ \\
\hline Age difference & $0.004(0.006)$ & $0.012 *(0.007)$ & $0.013 *(0.007)$ & $-0.016^{* *}(0.007)$ & $-0.011(0.008)$ & $0.009(0.006)$ & $0.014 *(0.006)$ & $0.008(0.006)$ & $-0.008(0.006)$ & $0.004(0.008)$ \\
\hline \multicolumn{11}{|c|}{ Education (ref: none) } \\
\hline $\begin{array}{l}\text { Primary } \\
\text { Pan }\end{array}$ & $0.146(0.105)$ & $0.309 * * *(0.109)$ & $0.245^{* *}(0.113)$ & $0.223 *(0.133)$ & $0.133(0.137)$ & $0.112(0.082)$ & $0.153^{*}(0.087)$ & $0.068(0.087)$ & $0.075(0.092)$ & $0.169 *(0.102)$ \\
\hline Secondary & $0.227^{* *}(0.109)$ & $0.168(0.112)$ & $0.005(0.118)$ & $-0.209(0.140)$ & $0.001(0.143)$ & $0.267 * * *(0.079)$ & $0.260 * * *(0.082)$ & $0.123(0.081)$ & $0.090(0.087)$ & $0.396 * * *(0.101)$ \\
\hline Higher & $0.614^{* * *}(0.131)$ & $0.494 * * *(0.134)$ & $0.487 * * *(0.141)$ & $0.206(0.166)$ & $0.696^{* * *}(0.171)$ & $0.399 * * *(0.093)$ & $0.388 * * *(0.095)$ & $0.249 * * *(0.094)$ & $0.210 * *(0.101)$ & $0.643^{* * *}(0.119)$ \\
\hline \multicolumn{11}{|c|}{ Spouse education (ref: none) } \\
\hline Primary & $-0.020(0.112)$ & $-0.018(0.109)$ & $-0.166(0.113)$ & $0.063(0.134)$ & $-0.040(0.139)$ & $-0.214 * *(0.104)$ & $0.009(0.104)$ & $-0.065(0.106)$ & $-0.077(0.115)$ & $-0.087(0.134)$ \\
\hline Secondary & $-0.032(0.099)$ & $-0.139(0.102)$ & $-0.130(0.107)$ & $-0.170(0.122)$ & $-0.213^{*}(0.124)$ & $-0.105(0.088)$ & $-0.054(0.091)$ & $-0.081(0.092)$ & $-0.035(0.096)$ & $-0.122(0.116)$ \\
\hline Higher & $0.010(0.119)$ & $-0.044(0.120)$ & $-0.011(0.125)$ & $0.012(0.144)$ & $-0.025(0.155)$ & $-0.122(0.095)$ & $-0.040(0.100)$ & $-0.038(0.100)$ & $-0.079(0.104)$ & $-0.131(0.125)$ \\
\hline \multicolumn{11}{|c|}{ Employed (ref: none) } \\
\hline Yes & $0.208^{* *}(0.095)$ & $0.033(0.094)$ & $0.056(0.098)$ & $0.213 *(0.110)$ & $0.183(0.115)$ & $0.269 * * *(0.081)$ & $0.413^{* * *}(0.081)$ & $0.361^{* * *}(0.082)$ & $0.228 * * *(0.083)$ & $0.468^{* * *}(0.107)$ \\
\hline \multicolumn{11}{|c|}{ Media exposure (ref: none) } \\
\hline Occasionally & $0.071(0.110)$ & $0.070(0.111)$ & $0.099(0.115)$ & $0.089(0.130)$ & $0.244 *(0.133)$ & $0.211 * *(0.104)$ & $0.264 * *(0.105)$ & $0.269 * * *(0.104)$ & $0.109(0.114)$ & $0.218 *(0.131)$ \\
\hline Weekly & $-0.257(0.278)$ & $-0.854 * *(0.351)$ & $-0.081(0.332)$ & $-0.050(0.349)$ & $-0.226(0.333)$ & $-0.007(0.182)$ & $0.200(0.172)$ & $0.217(0.178)$ & $-0.278(0.202)$ & $-0.014(0.208)$ \\
\hline Daily & $0.066(0.101)$ & $-0.019(0.103)$ & $0.017(0.109)$ & $0.146(0.121)$ & $0.212 *(0.126)$ & $0.243 * * *(0.091)$ & $0.262 * * *(0.092)$ & $0.342 * * *(0.092)$ & $0.189 *(0.100)$ & $0.336 * * *(0.113)$ \\
\hline \multicolumn{11}{|c|}{ Family structure (ref: joint) } \\
\hline Nuclear family & $0.445^{* * *}(0.078)$ & $0.756 * * *(0.079)$ & $0.738^{* * *}(0.081)$ & $0.157 *(0.093)$ & $0.177 *(0.099)$ & $0.362 * * *(0.072)$ & $0.600 * * *(0.073)$ & $0.531^{* * *}(0.072)$ & $0.154 *(0.086)$ & $-0.014(0.101)$ \\
\hline Household size & & & & & & $-0.025 * * *(0.006)$ & $-0.026 * * *(0.007)$ & $-0.031 * * *(0.007)$ & $-0.009(0.008)$ & $-0.023^{* * *}(0.008)$ \\
\hline \multicolumn{11}{|c|}{ Place of residence (ref: rural) } \\
\hline Urban & $0.196 * *(0.091)$ & $0.192 * *(0.096)$ & $0.271^{* * *}(0.097)$ & $0.012(0.118)$ & $0.104(0.124)$ & $0.147 * *(0.064)$ & $0.057(0.065)$ & $0.079(0.065)$ & $-0.019(0.072)$ & $-0.012(0.084)$ \\
\hline \multicolumn{11}{|c|}{ Province/ Region (ref: Islamabad) } \\
\hline Punjab & $0.007(0.124)$ & $-0.185(0.126)$ & $-0.126(0.133)$ & $0.184(0.148)$ & $0.176(0.179)$ & $0.067(0.069)$ & $-0.023(0.070)$ & $-0.044(0.069)$ & $0.150 * *(0.071)$ & $0.001(0.091)$ \\
\hline Sindh & $0.168(0.125)$ & $-0.161(0.126)$ & $-0.257 *(0.133)$ & $-0.107(0.150)$ & $-0.056(0.179)$ & $0.324 * * *(0.072)$ & $0.091(0.073)$ & $-0.029(0.072)$ & $0.052(0.073)$ & $0.117(0.098)$ \\
\hline KPK & $-0.670 * * *(0.144)$ & $-0.879 * * *(0.150)$ & $-0.853 * * *(0.158)$ & $-0.645 * * *(0.172)$ & $-0.78^{* * *}(0.195)$ & $-0.341 * * *(0.085)$ & $-0.531 * * *(0.087)$ & $-0.461 * * *(0.086)$ & $-0.191 * *(0.092)$ & $-0.574 * * *(0.106)$ \\
\hline Gilgit-Baltistan & $-0.001(0.181)$ & $-0.061(0.188)$ & $-0.608 * * *(0.196)$ & $-0.776 * * *(0.215)$ & $-0.394 *(0.237)$ & $-0.028(0.147)$ & $0.160(0.166)$ & $-0.027(0.151)$ & $-0.081(0.168)$ & $-0.284(0.242)$ \\
\hline Balochistan & $-0.377^{* *}(0.155)$ & $-0.375^{* *}(0.158)$ & $-0.438 * * *(0.167)$ & $-0.676 * * *(0.175)$ & $-0.84 * * *(0.199)$ & $-0.104(0.114)$ & $-0.220 *(0.119)$ & $-0.262 * *(0.118)$ & $-0.376 * * *(0.114)$ & $-0.588^{* * *}(0.131)$ \\
\hline \multicolumn{11}{|c|}{ Economic status (ref: poorest) } \\
\hline Poorer & $0.024(0.124)$ & $0.173(0.126)$ & $0.062(0.131)$ & $0.194(0.146)$ & $0.202(0.145)$ & & & & & \\
\hline Middle & $0.070(0.135)$ & $0.118(0.138)$ & $0.090(0.145)$ & $0.151(0.162)$ & $0.218(0.164)$ & & & & & \\
\hline Rich & $-0.167(0.149)$ & $0.030(0.156)$ & $-0.003(0.160)$ & $0.314 *(0.185)$ & $0.225(0.189)$ & & & & & \\
\hline Richest & $-0.205(0.170)$ & $-0.031(0.178)$ & $-0.066(0.184)$ & $0.183(0.221)$ & $0.244(0.229)$ & & & & & \\
\hline Marginal Effect & $0.057 * *(0.025)$ & $0.050 * *(0.023)$ & $0.055^{* *}(0.023)$ & $0.066 * *(0.032)$ & $0.058^{* *}(0.027)$ & $0.102 * * *(0.023)$ & $0.092 * * *(0.023)$ & $0.073 * * *(0.023)$ & $0.024(0.029)$ & $0.054 * *(0.023)$ \\
\hline Constant & $-1.527 * * *(0.216)$ & $-1.690 * * *(0.213)$ & $-1.789 * * *(0.223)$ & $-0.396(0.242)$ & $-0.226(0.264)$ & $-1.507 * * *(0.199)$ & $-1.781 * * *(0.204)$ & $-1.686 * * *(0.203)$ & $-0.388 *(0.217)$ & $-0.250(0.271)$ \\
\hline Observations & 2,831 & 2,833 & 2,832 & 1,781 & 1,773 & 5,022 & 5,032 & 5,028 & 4,005 & 3,982 \\
\hline
\end{tabular}


Table 16: Son Preference and female participation in decisionmaking - PSM estimates

\begin{tabular}{cccccc}
\hline $\begin{array}{c}\text { Propensity } \\
\text { score match }\end{array}$ & $\begin{array}{c}\mathbf{( 1 )} \\
\text { Healthcare } \\
\text { decisions }\end{array}$ & $\begin{array}{c}\text { Social } \\
\text { decisions }\end{array}$ & $\begin{array}{c}\mathbf{( 2 )} \\
\text { Consumption } \\
\text { decisions }\end{array}$ & $\begin{array}{c}\text { (4) } \\
\text { Financial } \\
\text { decisions }\end{array}$ & $\begin{array}{c}\text { All } \\
\text { decisions }\end{array}$ \\
\hline & & & & & \\
Unmatched & $0.072^{* * *}$ & $0.105^{* * *}$ & $0.103^{* * *}$ & 0.020 & $0.034^{* *}$ \\
ATT & $0.0641^{*}$ & $0.073^{* *}$ & $0.053^{*}$ & 0.036 & $0.063^{* *}$ \\
Observations & 10,025 & 10,043 & 10,034 & 8,540 & 8,509 \\
\hline Source: Authors' calculations. & & & & &
\end{tabular}

Source: Authors' calculations.

$* * * \mathrm{p}<0.01, * * \mathrm{p}<0.05, * \mathrm{p}<0.1$ 
Table 17: Son Preference and female participation in decisionmaking (Parity wise) - PSM estimates

\begin{tabular}{|c|c|c|c|c|c|c|c|c|c|c|}
\hline \multirow[b]{2}{*}{$\begin{array}{l}\text { Propensity } \\
\text { score match }\end{array}$} & \multicolumn{5}{|c|}{ Parity $\leq 3$} & \multicolumn{5}{|c|}{ Parity $>3$} \\
\hline & $\begin{array}{c}\text { Healthcare } \\
\text { decisions }\end{array}$ & $\begin{array}{c}\text { Social } \\
\text { decisions }\end{array}$ & $\begin{array}{c}\text { Consumption } \\
\text { decisions }\end{array}$ & $\begin{array}{r}\text { Financial } \\
\text { decisions }\end{array}$ & $\begin{array}{c}\text { All } \\
\text { decisions }\end{array}$ & $\begin{array}{c}\text { Healthcare } \\
\text { decisions }\end{array}$ & $\begin{array}{c}\text { Social } \\
\text { decisions }\end{array}$ & $\begin{array}{c}\text { Consumption } \\
\text { decisions }\end{array}$ & $\begin{array}{l}\text { Financial } \\
\text { decisions }\end{array}$ & $\begin{array}{c}\text { All } \\
\text { decisions }\end{array}$ \\
\hline Unmatched & $0.067 * * *$ & $0.086 * * *$ & $0.085^{* * *}$ & $0.037^{*}$ & $0.071 * * *$ & $-0.089 *$ & -0.040 & -0.026 & -0.039 & $-0.094^{*}$ \\
\hline ATT & $0.057 * *$ & $0.048^{*}$ & $0.043^{*}$ & 0.047 & $0.061^{* *}$ & -0.062 & -0.066 & -0.044 & -0.082 & -0.110 \\
\hline Observations & 4,908 & 4,911 & 4,910 & 3,792 & 3,785 & 4,968 & 4,983 & 4,975 & 4,607 & 4,724 \\
\hline
\end{tabular}

Source: Authors' calculations.

*** $\mathrm{p}<0.01,{ }^{* *} \mathrm{p}<0.05,{ }^{*} \mathrm{p}<0.1$

Table 18: Son Preference and female participation in decisionmaking - IPW and AIPW estimates

\begin{tabular}{|c|c|c|c|c|c|c|c|c|c|c|}
\hline \multirow{2}{*}{$\begin{array}{l}\text { Inverse- } \\
\text { Probability } \\
\text { weights }\end{array}$} & \multicolumn{2}{|c|}{ (1) } & \multicolumn{2}{|c|}{ (2) } & \multicolumn{2}{|c|}{ (3) } & \multicolumn{2}{|c|}{ (4) } & \multicolumn{2}{|c|}{ (5) } \\
\hline & $\begin{array}{l}\text { Healthcare } \\
\text { decisions }\end{array}$ & POmean & $\begin{array}{l}\text { Social } \\
\text { decisions }\end{array}$ & POmean & $\begin{array}{l}\text { Consumption } \\
\text { decisions }\end{array}$ & POmean & $\begin{array}{l}\text { Financial } \\
\text { decisions }\end{array}$ & POmean & $\begin{array}{l}\text { All } \\
\text { decisions }\end{array}$ & POmean \\
\hline \multirow[t]{2}{*}{ ATE } & $0.045^{* *}$ & $0.455 * * *$ & $0.041 *$ & $0.459 * * *$ & $0.041^{*}$ & $0.418 * * *$ & 0.041 & $.0452 * * *$ & $0.059 * *$ & $0.620 * * *$ \\
\hline & $(0.022)$ & $(0.021)$ & $(0.022)$ & $(0.022)$ & $(0.021)$ & $(0.021)$ & $(0.026)$ & $(0.026)$ & $(0.027)$ & $(0.027)$ \\
\hline \multirow[t]{2}{*}{ ATET } & $0.047 * *$ & $0.458 * * *$ & $0.042 *$ & $0.466^{* * *}$ & $0.042 *$ & $0.425^{* * *}$ & 0.043 & $0.450 * * *$ & $0.060 * *$ & $0.617^{* * *}$ \\
\hline & $(0.024)$ & $(0.023)$ & $(0.024)$ & $(0.024)$ & $(0.023)$ & $(0.023)$ & $(0.029)$ & $(0.028)$ & $(0.030)$ & $(0.029)$ \\
\hline Observation & 10,017 & 10,017 & 10,035 & 10,035 & 10,026 & 10,026 & 8,532 & 8,532 & 8,497 & 8,497 \\
\hline \multicolumn{11}{|l|}{ Augmented IPW } \\
\hline ATE & $\begin{array}{l}0.044 * \\
(0.022)\end{array}$ & $\begin{array}{l}0.456 * * * \\
(0.022)\end{array}$ & 0.038* & $\begin{array}{l}0.462 * * * \\
002)\end{array}$ & 0.038* & $\begin{array}{l}0.421 * * * \\
(020)\end{array}$ & $\begin{array}{l}0.042 \\
(0028)\end{array}$ & $0.451^{* * *}$ & $0.061^{*}$ & $0.618 * * *$ \\
\hline Observation & 10,017 & 10,017 & 10,035 & 10,035 & 10,026 & 10,026 & 8,532 & 8,532 & 8,497 & 8,497 \\
\hline
\end{tabular}

Source: Authors' calculations.

Robust standard errors in parentheses

*** $\mathrm{p}<0.01, * * \mathrm{p}<0.05, * \mathrm{p}<0.1$ 
Figure 4.1: Density distribution for the estimated propensity scores for women with no son vs. women with at least one son

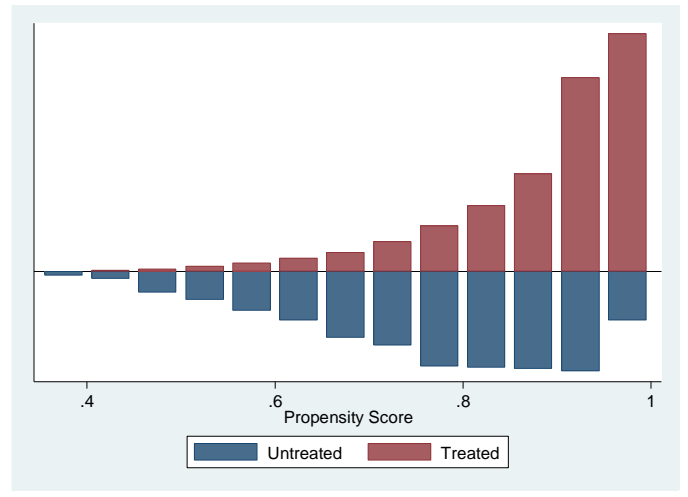

(Outcome-Health decisions) Source: Authors' calculations.

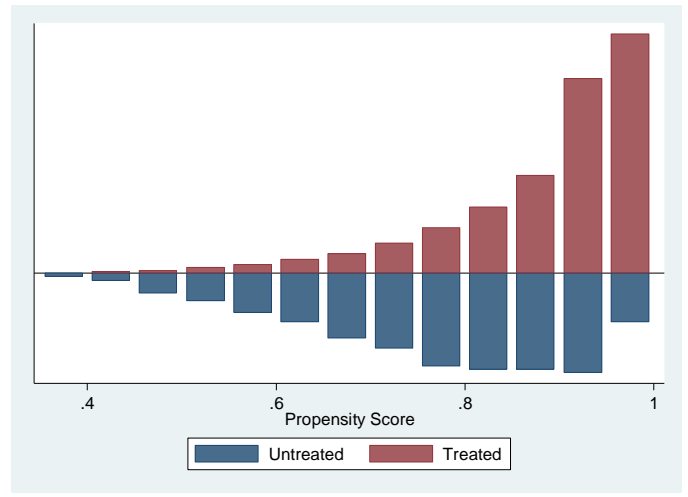

(Outcome-Consumption decisions) Source: Authors' calculations.

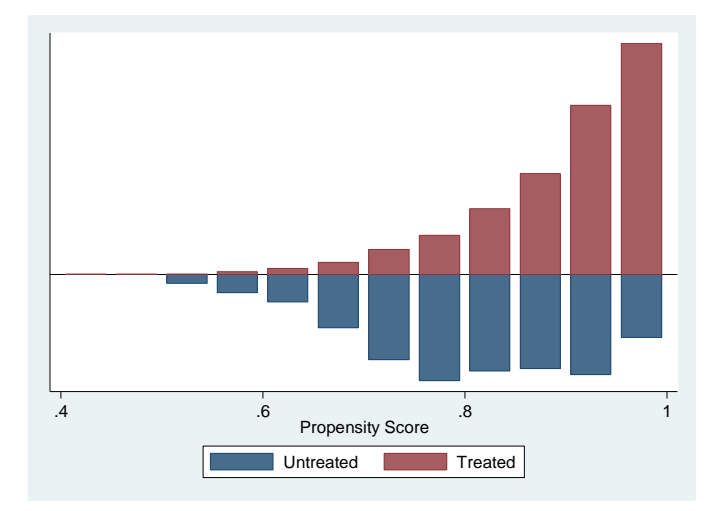

(Outcome-All decisions)

Source: Authors' calculations.

\section{Source: Authors" calculations.}

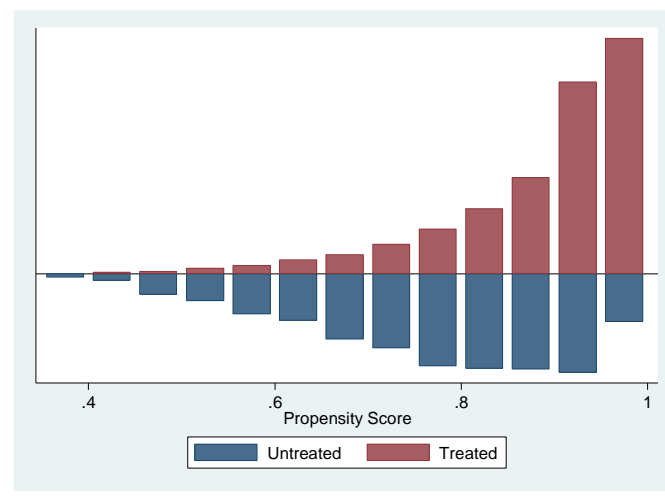

(Outcome-Social decisions)

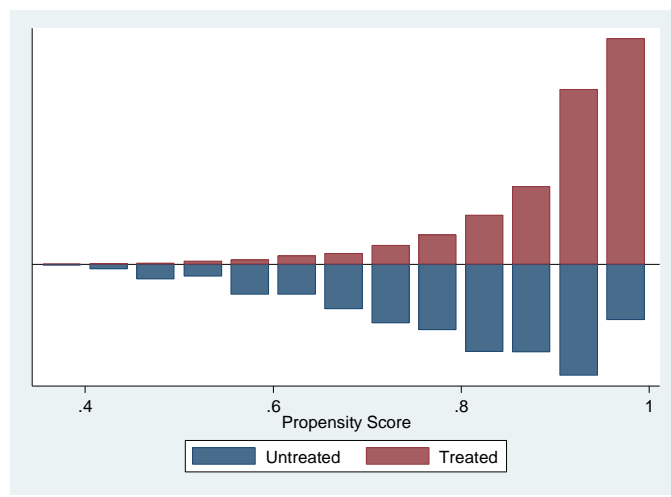

(Outcome-Financial decisions) 
Figure 4.2: Density distribution for the estimated propensity scores for having no son and having at least one son (Parity wise)

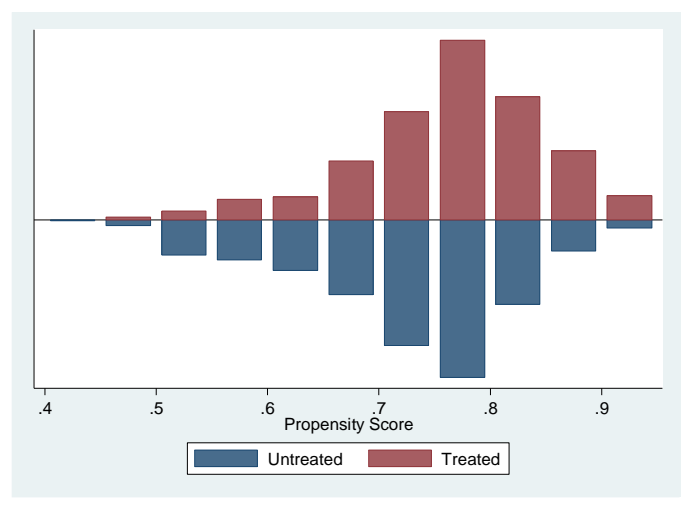

(Outcome- Health decisions: Parity $\leq 3$ )

Source: Authors’ calculations.

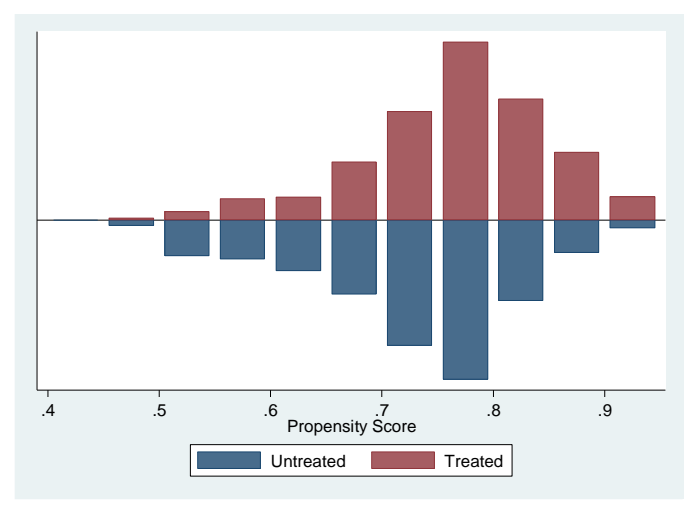

(Outcome-Social decisions: Parity $\leq 3$ )

Source: Authors’ calculations.

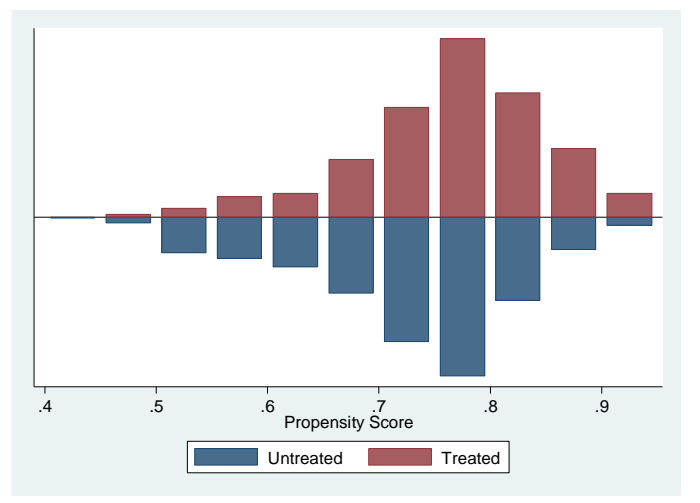

(Outcome- Consumption decisions: Parity $\leq 3$ )

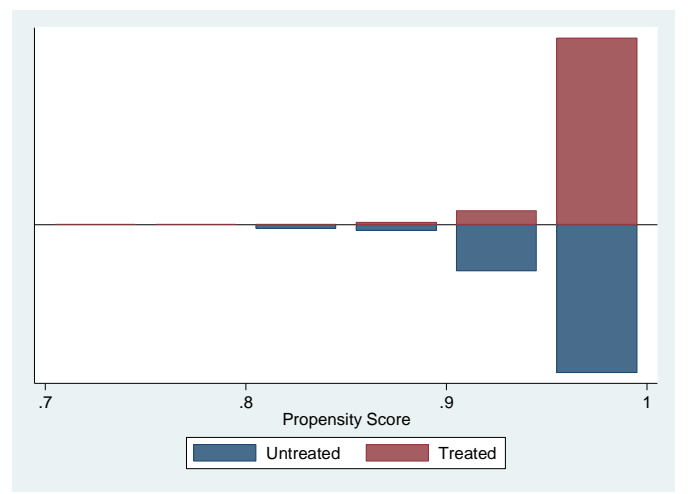

(Outcome- Health decisions: Parity>3)

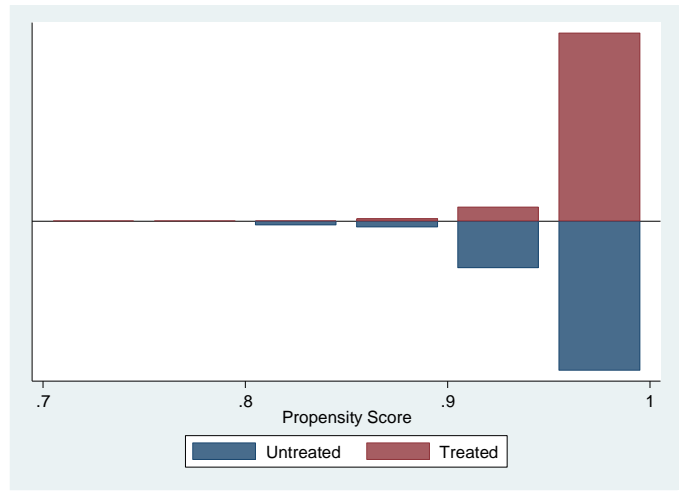

(Outcome-Social decisions: Parity> 3)

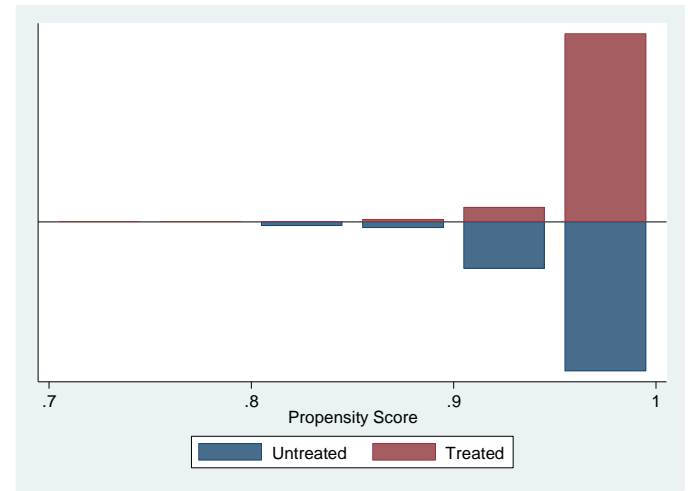

(Outcome- Consumption decisions: Parity>3)

Source: Authors’ calculations. 


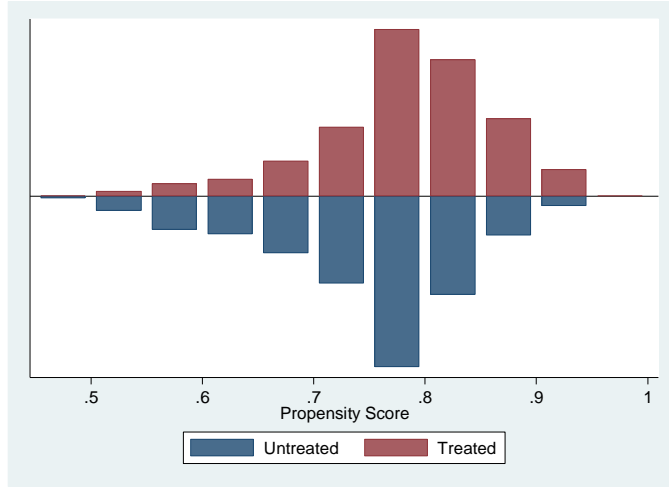

(Outcome-Financial decisions: Parity $\leq$ )

Source: Authors’ calculations.

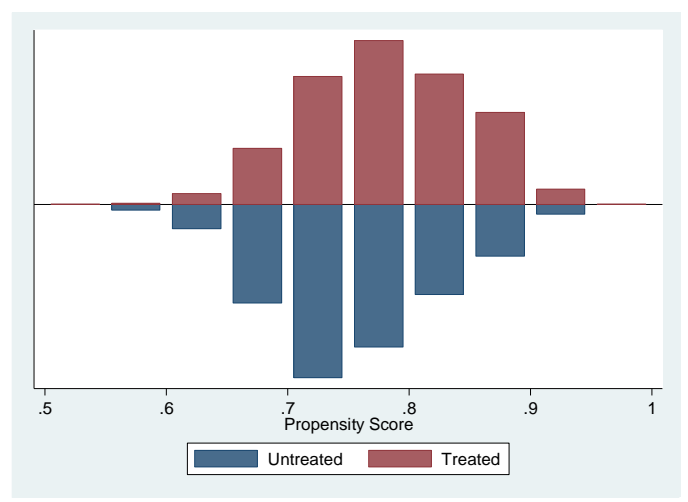

(Outcome-All decisions: Parity $\leq$ 3)

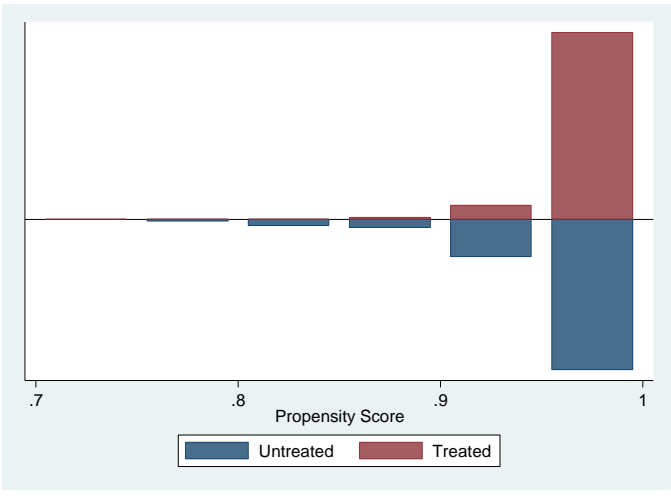

(Outcome-Financial decisions: Parity> 3)

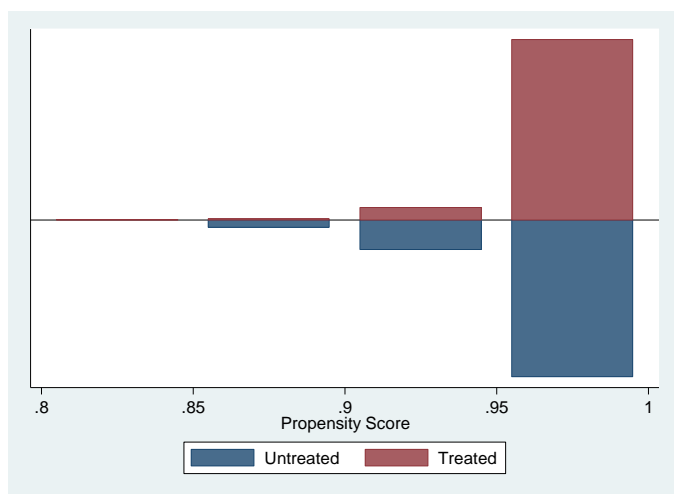

(Outcome-All decisions: Parity> 3)

Source: Authors' calculations. 
Table 19: Checking balance of confounders between treated and untreated- PSM

\begin{tabular}{llll}
\hline Variables & Mean in treated & Mean in Untreated & Standardised diff. \\
\hline Age & 34.54 & 28.03 & 0.858 \\
Age difference & 5.52 & 5.11 & 0.081 \\
Education & 0.79 & 1.15 & -0.318 \\
Employed & 0.21 & 0.17 & 0.107 \\
Media exposure & 1.63 & 1.75 & -0.096 \\
Family structure & 0.73 & 0.49 & 0.511 \\
Household size & 9.02 & 8.64 & 0.073 \\
Place of residence & 0.48 & 0.53 & -0.102 \\
Province/ Region & 3.45 & 3.3 & 0.097 \\
Economic status & 3.1 & 3.26 & -0.107 \\
\hline
\end{tabular}

Source: Authors' calculations.

Table 20.1: Sensitivity analysis-Son preference and female participation in household decision making-Health decisions

\begin{tabular}{|c|c|c|c|c|}
\hline & \multicolumn{2}{|c|}{ Mantel-Haenszel bounds } & \multicolumn{2}{|c|}{ Significance level } \\
\hline $\operatorname{Gamma}(\Gamma)$ & Maximum & Minimum & Maximum & Minimum \\
\hline 1 & 3.979 & 3.979 & 0.000 & 0.000 \\
\hline 1.05 & 3.217 & 4.743 & 0.000 & 0.000 \\
\hline 1.1 & 2.492 & 5.473 & 0.006 & 0.000 \\
\hline 1.15 & 1.800 & 6.172 & 0.035 & 0.000 \\
\hline 1.2 & 1.138 & 6.843 & 0.127 & 0.000 \\
\hline 1.25 & 0.504 & 7.490 & 0.307 & 0.000 \\
\hline 1.3 & 0.041 & 8.113 & 0.483 & 0.000 \\
\hline 1.35 & 0.627 & 8.714 & 0.265 & 0.000 \\
\hline 1.4 & 1.192 & 9.296 & 0.116 & 0.000 \\
\hline 1.45 & 1.738 & 9.859 & 0.041 & 0.000 \\
\hline 1.5 & 2.266 & 10.405 & 0.011 & 0.000 \\
\hline
\end{tabular}

Table 20.2: Sensitivity analysis-Son preference and female participation in household decision making- Social decisions

\begin{tabular}{lllll}
\hline & \multicolumn{2}{l}{ Mantel-Haenszel bounds } & \multicolumn{2}{l}{ Significance level } \\
\hline Gamma $(\Gamma)$ & \multicolumn{2}{l}{ Maximum } & Minimum & \multicolumn{2}{l}{ Maximum } & Minimum \\
\hline & & & & \\
1.05 & 5.471 & 5.471 & 0.000 & 0.000 \\
1.1 & 4.709 & 6.235 & 0.000 & 0.000 \\
1.15 & 3.985 & 6.965 & 0.000 & 0.000 \\
1.2 & 3.295 & 7.666 & 0.000 & 0.000 \\
1.25 & 2.635 & 8.339 & 0.004 & 0.000 \\
1.3 & 2.002 & 8.987 & 0.023 & 0.000 \\
1.35 & 1.395 & 9.613 & 0.081 & 0.000 \\
1.4 & 0.812 & 10.217 & 0.208 & 0.000 \\
1.45 & 0.249 & 10.801 & 0.402 & 0.000 \\
1.5 & 0.228 & 11.368 & 0.410 & 0.000 \\
\hline Source: Authors' calculations. & 11.918 & 0.226 & 0.000
\end{tabular}


Table 20.3: Sensitivity analysis-Son preference and female participation in household decision making- Consumption decisions

\begin{tabular}{lllll}
\hline & \multicolumn{2}{l}{ Mantel-Haenszel bounds } & \multicolumn{2}{l}{ Significance level } \\
\hline Gamma $(\Gamma)$ & \multicolumn{2}{l}{ Maximum } & Minimum & \multicolumn{2}{l}{ Maximum } & Minimum \\
1 & & & & 0.000 \\
1.05 & 5.380 & 5.380 & 0.000 & 0.000 \\
1.1 & 4.631 & 6.131 & 0.000 & 0.000 \\
1.15 & 3.918 & 6.850 & 0.000 & 0.000 \\
1.2 & 3.239 & 7.539 & 0.001 & 0.000 \\
1.25 & 2.590 & 8.202 & 0.005 & 0.000 \\
1.3 & 1.968 & 8.839 & 0.025 & 0.000 \\
1.35 & 1.371 & 9.455 & 0.085 & 0.000 \\
1.4 & 0.796 & 10.049 & 0.213 & 0.000 \\
1.45 & 0.243 & 10.624 & 0.404 & 0.000 \\
1.5 & 0.224 & 11.181 & 0.411 & 0.000 \\
\hline Source: Authors' & 0.740 & 11.722 & 0.230 & \\
\hline
\end{tabular}

Table 20.4: Sensitivity analysis-Son preference and female participation in household decision making- Financial decisions

\begin{tabular}{lllll}
\hline & \multicolumn{2}{l}{ Mantel-Haenszel bounds } & \multicolumn{2}{l}{ Significance level } \\
\hline Gamma $(\Gamma)$ & \multicolumn{2}{l}{ Maximum } & Minimum & \multicolumn{2}{l}{ Maximum } & Minimum \\
1 & & & & 0.234 \\
1.05 & 0.727 & 0.727 & 0.234 & 0.082 \\
1.1 & 0.060 & 1.394 & 0.476 & 0.021 \\
1.15 & 0.502 & 2.031 & 0.308 & 0.004 \\
1.2 & 1.110 & 2.640 & 0.045 & 0.001 \\
1.25 & 1.692 & 3.224 & 0.012 & 0.000 \\
1.3 & 2.251 & 3.786 & 0.003 & 0.000 \\
1.35 & 2.789 & 4.326 & 0.000 & 0.000 \\
1.4 & 3.307 & 4.847 & 0.000 & 0.000 \\
1.45 & 3.807 & 5.350 & 0.000 & 0.000 \\
1.5 & 4.290 & 5.837 & 0.000 & 0.000
\end{tabular}

Table 20.5: Sensitivity analysis-Son preference and female participation in household decision making- All decisions

\begin{tabular}{lllll}
\hline & \multicolumn{2}{l}{ Mantel-Haenszel bounds } & \multicolumn{2}{l}{ Significance level } \\
\hline Gamma $(\Gamma)$ & \multicolumn{2}{l}{ Maximum } & Minimum & \multicolumn{2}{l}{ Maximum } & Minimum \\
\hline & 2.282 & & & 0.011 \\
1.05 & 1.640 & 2.282 & 0.011 & 0.002 \\
1.1 & 1.028 & 2.925 & 0.051 & 0.000 \\
1.15 & 0.444 & 4.540 & 0.152 & 0.000 \\
1.2 & 0.039 & 4.694 & 0.329 & 0.000 \\
1.25 & 0.576 & 5.238 & 0.484 & 0.000 \\
1.3 & 1.092 & 5.762 & 0.282 & 0.000 \\
1.35 & 1.589 & 6.268 & 0.137 & 0.000 \\
1.4 & 2.068 & 6.757 & 0.056 & 0.000 \\
1.45 & 2.530 & 7.230 & 0.019 & 0.000 \\
1.5 & 2.978 & 7.690 & 0.006 & 0.000 \\
\hline Source: Authors' calculations. & & 0.001 &
\end{tabular}

Source: Authors’ calculations. 
Table 20.6: Sensitivity analysis-Son preference and female participation in household decision making-Health decisions (Parity $\leq 3$ )

\begin{tabular}{lllll}
\hline & \multicolumn{2}{l}{ Mantel-Haenszel bounds } & \multicolumn{2}{l}{ Significance level } \\
\hline Gamma $(\Gamma)$ & \multicolumn{2}{l}{ Maximum } & Minimum & \multicolumn{2}{l}{ Maximum } & Minimum \\
1 & & & & 0.001 \\
1.05 & 3.220 & 3.220 & 0.001 & 0.000 \\
1.1 & 2.551 & 3.891 & 0.005 & 0.000 \\
1.15 & 1.913 & 4.532 & 0.028 & 0.000 \\
1.2 & 1.304 & 5.145 & 0.096 & 0.000 \\
1.25 & 0.721 & 5.734 & 0.235 & 0.000 \\
1.3 & 0.162 & 6.299 & 0.436 & 0.000 \\
1.35 & 0.302 & 6.844 & 0.381 & 0.000 \\
1.4 & 0.818 & 7.369 & 0.207 & 0.000 \\
1.45 & 1.316 & 7.877 & 0.094 & 0.000 \\
1.5 & 1.797 & 8.368 & 0.036 & 0.000 \\
\hline
\end{tabular}

Table 20.7: Sensitivity analysis-Son preference and female participation in household decision making-Health decisions (Parity>3)

\begin{tabular}{lllll}
\hline & \multicolumn{2}{l}{ Mantel-Haenszel bounds } & \multicolumn{2}{l}{ Significance level } \\
\hline Gamma $(\Gamma)$ & \multicolumn{2}{l}{ Maximum } & Minimum & \multicolumn{2}{l}{ Maximum } & Minimum \\
\hline & & & & \\
1 & 1.741 & 1.741 & 0.041 & 0.041 \\
1.05 & 1.993 & 1.491 & 0.023 & 0.068 \\
1.1 & 2.233 & 1.253 & 0.013 & 0.105 \\
1.15 & 2.465 & 1.026 & 0.007 & 0.152 \\
1.2 & 2.687 & 0.809 & 0.004 & 0.209 \\
1.25 & 2.901 & 0.602 & 0.002 & 0.274 \\
1.3 & 3.108 & 0.402 & 0.001 & 0.344 \\
1.35 & 3.308 & 0.211 & 0.000 & 0.417 \\
1.4 & 3.502 & 0.026 & 0.000 & 0.490 \\
1.45 & 3.691 & -0.046 & 0.000 & 0.518 \\
1.5 & 3.873 & 0.125 & 0.000 & 0.450
\end{tabular}

Table 20.8: Sensitivity analysis-Son preference and female participation in household decision making-Social decisions (Parity $\leq 3$ )

\begin{tabular}{lllll}
\hline & \multicolumn{2}{l}{ Mantel-Haenszel bounds } & \multicolumn{2}{l}{ Significance level } \\
\hline Gamma $(\Gamma)$ & \multicolumn{2}{l}{ Maximum } & Minimum & \multicolumn{2}{l}{ Maximum } & Minimum \\
\hline & & & & \\
1 & 4.280 & 4.280 & 0.000 & 0.000 \\
1.05 & 3.610 & 4.952 & 0.000 & 0.000 \\
1.1 & 2.971 & 5.594 & 0.001 & 0.000 \\
1.15 & 2.362 & 6.209 & 0.009 & 0.000 \\
1.2 & 1.779 & 6.799 & 0.038 & 0.000 \\
1.25 & 1.220 & 7.367 & 0.111 & 0.000 \\
1.3 & 0.684 & 7.914 & 0.247 & 0.000 \\
1.35 & 0.168 & 8.441 & 0.433 & 0.000 \\
1.4 & 0.256 & 8.951 & 0.399 & 0.000 \\
1.45 & 0.736 & 9.445 & 0.231 & 0.000 \\
1.5 & 1.199 & 9.923 & 0.115 & 0.000 \\
\hline Source: Authors' calculations. & & &
\end{tabular}


Table 20.9: Sensitivity analysis-Son preference and female participation in household decision making-Social decisions (Parity>3)

\begin{tabular}{lllll}
\hline & \multicolumn{2}{l}{ Mantel-Haenszel bounds } & \multicolumn{2}{l}{ Significance level } \\
\hline Gamma $(\Gamma)$ & \multicolumn{2}{l}{ Maximum } & Minimum & \multicolumn{2}{l}{ Maximum } & Minimum \\
\hline & & & & \\
1.05 & 0.726 & 0.726 & 0.234 & 0.234 \\
1.1 & 0.978 & 0.475 & 0.164 & 0.317 \\
1.15 & 1.218 & 0.236 & 0.112 & 0.407 \\
1.2 & 1.448 & 0.008 & 0.074 & 0.497 \\
1.25 & 1.669 & 0.016 & 0.048 & 0.494 \\
1.3 & 1.882 & 0.225 & 0.030 & 0.411 \\
1.35 & 2.087 & 0.426 & 0.018 & 0.335 \\
1.4 & 2.285 & 0.620 & 0.011 & 0.268 \\
1.45 & 2.477 & 0.807 & 0.007 & 0.210 \\
1.5 & 2.662 & 0.987 & 0.004 & 0.162 \\
\hline Source: Authors' calculations. & 1.162 & 0.002 & 0.123 \\
\end{tabular}

Table 20.10: Sensitivity analysis-Son preference and female participation in household decision making-Consumption decisions (Parity $\leq 3$ )

\begin{tabular}{|c|c|c|c|c|}
\hline \multirow[b]{2}{*}{ Gamma $(\Gamma)$} & \multicolumn{2}{|c|}{ Mantel-Haenszel bounds } & \multicolumn{2}{|c|}{ Significance level } \\
\hline & Maximum & Minimum & Maximum & Minimum \\
\hline 1 & 3.976 & 3.976 & 0.000 & 0.000 \\
\hline 1.05 & 3.318 & 4.636 & 0.000 & 0.000 \\
\hline 1.1 & 2.691 & 5.266 & 0.004 & 0.000 \\
\hline 1.15 & 2.093 & 5.869 & 0.018 & 0.000 \\
\hline 1.2 & 1.521 & 6.449 & 0.064 & 0.000 \\
\hline 1.25 & 0.973 & 7.005 & 0.165 & 0.000 \\
\hline 1.3 & 0.446 & 7.542 & 0.328 & 0.000 \\
\hline 1.35 & -0.014 & 8.059 & 0.506 & 0.000 \\
\hline 1.4 & 0.474 & 8.560 & 0.318 & 0.000 \\
\hline 1.45 & 0.945 & 9.043 & 0.172 & 0.000 \\
\hline 1.5 & 1.400 & 9.512 & 0.081 & 0.000 \\
\hline
\end{tabular}

Source: Authors' calculations.

Table 20.11: Sensitivity analysis-Son preference and female participation in household decision making-Consumption decisions (Parity $>3$ )

\begin{tabular}{|c|c|c|c|c|}
\hline \multirow[b]{2}{*}{ Gamma $(\Gamma)$} & \multicolumn{2}{|c|}{ Mantel-Haenszel bounds } & \multicolumn{2}{|c|}{ Significance level } \\
\hline & Maximum & Minimum & Maximum & Minimum \\
\hline 1 & 0.449 & 0.449 & 0.327 & 0.327 \\
\hline 1.05 & 0.702 & 0.196 & 0.241 & 0.422 \\
\hline 1.1 & 0.944 & -0.045 & 0.172 & 0.518 \\
\hline 1.15 & 1.176 & 0.082 & 0.120 & 0.467 \\
\hline 1.2 & 1.398 & 0.303 & 0.081 & 0.381 \\
\hline 1.25 & 1.612 & 0.515 & 0.054 & 0.303 \\
\hline 1.3 & 1.818 & 0.718 & 0.035 & 0.236 \\
\hline 1.35 & 2.016 & 0.914 & 0.022 & 0.180 \\
\hline 1.4 & 2.209 & 1.103 & 0.014 & 0.135 \\
\hline 1.45 & 2.395 & 1.286 & 0.008 & 0.099 \\
\hline 1.5 & 2.575 & 1.463 & 0.005 & 0.072 \\
\hline
\end{tabular}

Source: Authors' calculations. 
Table 20.12: Sensitivity analysis-Son preference and female participation in household decision making-Financial decisions (Parity $\leq 3$ )

\begin{tabular}{lllll}
\hline & \multicolumn{2}{l}{ Mantel-Haenszel bounds } & \multicolumn{2}{l}{ Significance level } \\
\hline Gamma $(\Gamma)$ & \multicolumn{2}{l}{ Maximum } & Minimum & \multicolumn{2}{l}{ Maximum } & Minimum \\
\hline & & & & \\
1.05 & 0.874 & 0.874 & 0.191 & 0.191 \\
1.1 & 0.288 & 1.460 & 0.387 & 0.072 \\
1.15 & 0.187 & 2.020 & 0.426 & 0.022 \\
1.2 & 0.721 & 2.555 & 0.235 & 0.005 \\
1.25 & 1.232 & 3.068 & 0.109 & 0.001 \\
1.3 & 1.723 & 3.560 & 0.042 & 0.000 \\
1.35 & 2.195 & 4.034 & 0.014 & 0.000 \\
1.4 & 2.649 & 4.491 & 0.004 & 0.000 \\
1.45 & 3.087 & 4.932 & 0.001 & 0.000 \\
1.5 & 3.511 & 5.359 & 0.000 & 0.000 \\
\hline Source: Authors' calculations. & 5.772 & 0.000 & 0.000 \\
\end{tabular}

Source: Authors' calculations.

Table 20.13: Sensitivity analysis-Son preference and female participation in household decision making-Financial decisions (Parity $>3$ )

\begin{tabular}{lllll}
\hline & \multicolumn{2}{l}{ Mantel-Haenszel bounds } & \multicolumn{2}{l}{ Significance level } \\
\hline Gamma $(\Gamma)$ & \multicolumn{2}{l}{ Maximum } & Minimum & \multicolumn{2}{l}{ Maximum } & Minimum \\
1 & & & & 0.251 \\
1.05 & 0.671 & 0.671 & 0.251 & 0.333 \\
1.1 & 0.911 & 0.431 & 0.181 & 0.420 \\
1.15 & 1.141 & 0.202 & 0.127 & 0.507 \\
1.2 & 1.362 & -0.017 & 0.087 & 0.491 \\
1.25 & 1.573 & 0.023 & 0.058 & 0.412 \\
1.3 & 1.777 & 0.223 & 0.038 & 0.339 \\
1.35 & 1.973 & 0.416 & 0.024 & 0.274 \\
1.4 & 2.162 & 0.602 & 0.015 & 0.218 \\
1.45 & 2.345 & 0.781 & 0.010 & 0.170 \\
1.5 & 2.523 & 0.954 & 0.006 & 0.131 \\
\hline
\end{tabular}

Source: Authors' calculations.

Table 20.14: Sensitivity analysis-Son preference and female participation in household decision making-All decisions (Parity $\leq 3$ )

\begin{tabular}{|c|c|c|c|c|}
\hline \multirow[b]{2}{*}{ Gamma $(\Gamma)$} & \multicolumn{2}{|c|}{ Mantel-Haenszel bounds } & \multicolumn{2}{|c|}{ Significance level } \\
\hline & Maximum & Minimum & Maximum & Minimum \\
\hline 1 & 4.244 & 4.244 & 0.000 & 0.000 \\
\hline 1.05 & 3.680 & 4.811 & 0.000 & 0.000 \\
\hline 1.1 & 3.143 & 5.353 & 0.001 & 0.000 \\
\hline 1.15 & 2.631 & 5.871 & 0.004 & 0.000 \\
\hline 1.2 & 2.141 & 6.370 & 0.016 & 0.000 \\
\hline 1.25 & 1.672 & 6.850 & 0.047 & 0.000 \\
\hline 1.3 & 1.221 & 7.313 & 0.111 & 0.000 \\
\hline 1.35 & 0.788 & 7.760 & 0.215 & 0.000 \\
\hline 1.4 & 0.370 & 8.192 & 0.356 & 0.000 \\
\hline 1.45 & -0.032 & 8.611 & 0.513 & 0.000 \\
\hline 1.5 & 0.334 & 9.018 & 0.369 & 0.000 \\
\hline
\end{tabular}

Source: Authors' calculations. 
Table 20.15: Sensitivity analysis-Son preference and female participation in household decision making-All decisions (Parity $>3$ )

\begin{tabular}{lllll}
\hline & \multicolumn{2}{l}{ Mantel-Haenszel bounds } & \multicolumn{2}{l}{ Significance level } \\
\hline Gamma $(\Gamma)$ & Maximum & Minimum & Maximum & Minimum \\
\hline \multicolumn{1}{l}{} & & & & \\
1 & 1.858 & 1.858 & 0.032 & 0.032 \\
1.05 & 2.071 & 1.646 & 0.019 & 0.050 \\
1.1 & 2.275 & 1.445 & 0.011 & 0.074 \\
1.15 & 2.471 & 1.254 & 0.007 & 0.105 \\
1.2 & 2.660 & 1.071 & 0.004 & 0.142 \\
1.25 & 2.842 & 0.896 & 0.002 & 0.185 \\
1.3 & 3.018 & 0.729 & 0.001 & 0.233 \\
1.35 & 3.188 & 0.568 & 0.001 & 0.285 \\
1.4 & 3.354 & 0.413 & 0.000 & 0.340 \\
1.45 & 3.514 & 0.263 & 0.000 & 0.396 \\
1.5 & 3.670 & 0.119 & 0.000 & 0.453 \\
\hline Source: Authors' calculations. & & &
\end{tabular}


Table 21: Son Preference and female participation in decisionmaking (women with 'unhealthy' BMI) - probit estimation

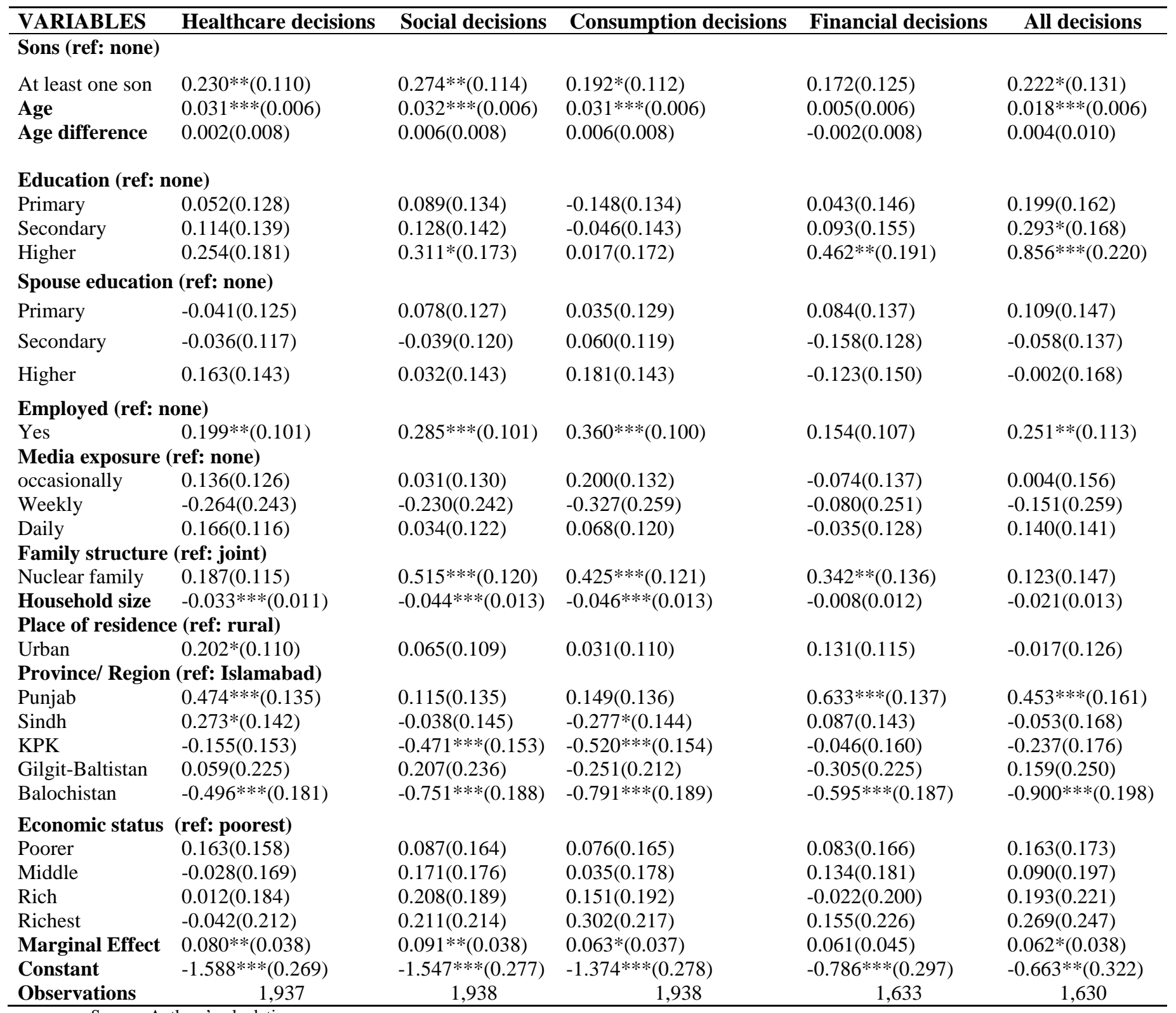

Source: Authors' calculations. Standard errors in parentheses *** $\mathrm{p}<0.01,{ }^{* *} \mathrm{p}<0.05,{ }^{*} \mathrm{p}<0.1$ 
Table 22: Son Preference and female participation in decisionmaking (number of children as control) - probit estimation

\begin{tabular}{|c|c|c|c|c|c|}
\hline VARIABLES & $\begin{array}{l}\text { Healthcare } \\
\text { decisions }\end{array}$ & Social decisions & $\begin{array}{c}\text { Consumption } \\
\text { decisions }\end{array}$ & $\begin{array}{l}\text { Financial } \\
\text { decisions }\end{array}$ & All decisions \\
\hline \multicolumn{6}{|l|}{ Sons (ref: none) } \\
\hline At least one son & $0.150 * * *(0.054)$ & $0.199 * * *(0.059)$ & $0.159 * * *(0.061)$ & $0.069(0.065)$ & $0.239 * * *(0.071)$ \\
\hline Age & $0.025 * * *(0.003)$ & $0.029 * * *(0.004)$ & $0.030 * * *(0.003)$ & $0.009 * * *(0.003)$ & $0.020 * * *(0.004)$ \\
\hline Age difference & $0.007 * *(0.004)$ & $0.011^{* * *}(0.003)$ & $0.008 * *(0.004)$ & $-0.002(0.004)$ & $0.001(0.005)$ \\
\hline \multicolumn{6}{|c|}{ Education (ref: none) } \\
\hline Primary & $0.067(0.051)$ & $0.149 * * *(0.056)$ & $0.042(0.054)$ & $0.058(0.068)$ & $0.134 *(0.069)$ \\
\hline Secondary & $0.261^{* * *}(0.073)$ & $0.163 * *(0.065)$ & $0.154 * *(0.070)$ & $0.095(0.086)$ & $0.299 * * *(0.095)$ \\
\hline Higher & $0.468 * * *(0.097)$ & $0.407 * * *(0.095)$ & $0.379 * * *(0.095)$ & $0.165(0.105)$ & $0.626 * * *(0.111)$ \\
\hline \multicolumn{6}{|c|}{ Spouse education (ref: none) } \\
\hline Primary & $-0.140 * *(0.061)$ & $-0.010(0.059)$ & $-0.067(0.064)$ & $-0.078(0.068)$ & $-0.044(0.066)$ \\
\hline Secondary & $-0.030(0.054)$ & $-0.026(0.057)$ & $-0.031(0.056)$ & $-0.088(0.057)$ & $-0.052(0.059)$ \\
\hline Higher & $0.009(0.067)$ & $0.026(0.071)$ & $0.027(0.077)$ & $-0.104(0.071)$ & $-0.018(0.085)$ \\
\hline \multicolumn{6}{|c|}{ Employed (ref: none) } \\
\hline Yes & $0.196 * * *(0.049)$ & $0.215 * * *(0.043)$ & $0.252 * * *(0.049)$ & $0.183 * * *(0.055)$ & $0.255^{* * *}(0.053)$ \\
\hline \multicolumn{6}{|c|}{ Media exposure (ref: none) } \\
\hline occasionally & $0.123 * *(0.060)$ & $0.107 *(0.058)$ & $0.125 *(0.065)$ & $0.092(0.063)$ & $0.218 * * *(0.065)$ \\
\hline Weekly & $-0.037(0.112)$ & $0.003(0.118)$ & $0.132(0.105)$ & $-0.067(0.140)$ & $0.140(0.139)$ \\
\hline Daily & $0.151 * * *(0.056)$ & $0.135 * *(0.054)$ & $0.175 * * *(0.053)$ & $0.103 *(0.058)$ & $0.188 * * *(0.065)$ \\
\hline \multicolumn{6}{|c|}{ Family structure (ref: joint) } \\
\hline Nuclear family & $0.465 * * *(0.045)$ & $0.663 * * *(0.049)$ & $0.651 * * *(0.046)$ & $0.189 * * *(0.055)$ & $0.137 * *(0.064)$ \\
\hline Total Children & $-0.025 * *(0.011)$ & $-0.023 * *(0.011)$ & $-0.030 * * *(0.011)$ & $-0.030 * * *(0.011)$ & $-0.041 * * *(0.012)$ \\
\hline \multicolumn{6}{|c|}{ Place of residence (ref: rural) } \\
\hline Urban & $0.230 * * *(0.066)$ & $0.178 * * *(0.059)$ & $0.192 * * *(0.059)$ & $0.129 *(0.068)$ & $0.161 *(0.083)$ \\
\hline \multicolumn{6}{|c|}{ Province/ Region (ref: Islamabad) } \\
\hline Punjab & $0.288 * * *(0.079)$ & $0.158 * *(0.062)$ & $0.161^{* *}(0.074)$ & $0.255 * * *(0.086)$ & $0.249 * * *(0.092)$ \\
\hline Sindh & $0.021(0.088)$ & $-0.167 * *(0.073)$ & $-0.305 * * *(0.083)$ & $-0.158 *(0.096)$ & $-0.300 * * *(0.095)$ \\
\hline KPK & $-0.277 * * *(0.091)$ & $-0.410 * * *(0.079)$ & $-0.381 * * *(0.090)$ & $-0.287 * * *(0.100)$ & $-0.403^{* * *}(0.102)$ \\
\hline Gilgit-Baltistan & $-0.175(0.161)$ & $-0.149(0.165)$ & $-0.458 * * *(0.134)$ & $-0.700 * * *(0.137)$ & $-0.504 * * *(0.180)$ \\
\hline Balochistan & $-0.534 * * *(0.122)$ & $-0.652 * * *(0.113)$ & $-0.699 * * *(0.124)$ & $-0.659 * * *(0.127)$ & $-0.942 * * *(0.128)$ \\
\hline \multicolumn{6}{|c|}{ Economic status (ref: poorest) } \\
\hline Poorer & $0.194 * * *(0.063)$ & $0.196 * * *(0.065)$ & $0.202 * * *(0.064)$ & $0.304 * * *(0.063)$ & $0.149 *(0.087)$ \\
\hline Middle & $0.099(0.081)$ & $0.117(0.071)$ & $0.131 *(0.071)$ & $0.316 * * *(0.082)$ & $0.198 * *(0.083)$ \\
\hline Rich & $0.075(0.088)$ & $0.089(0.075)$ & $0.091(0.078)$ & $0.213^{* *}(0.092)$ & $0.146(0.094)$ \\
\hline Richest & $0.002(0.105)$ & $0.080(0.096)$ & $0.038(0.095)$ & $0.229 *(0.117)$ & $0.171(0.113)$ \\
\hline Marginal effect & $0.052 * * *(0.019)$ & $0.068 * * *(0.020)$ & $0.054 * * *(0.020)$ & $0.025(0.023)$ & $0.069 * * *(0.021)$ \\
\hline Constant & $-1.585^{* * *}(0.141)$ & $-1.831 * * *(0.128)$ & $-1.842 * * *(0.137)$ & $-0.585^{* * *}(0.142)$ & $-0.577 * * *(0.148)$ \\
\hline Observations & 10,017 & 10,035 & 10,026 & 8,532 & 8,497 \\
\hline
\end{tabular}

Source: Authors' calculations.

Standard errors in parentheses

$* * * \mathrm{p}<0.01, * * \mathrm{p}<0.05, * \mathrm{p}<0.1$ 
Table 23: Son Preference and female participation in decisionmaking (Alternative wealth indicator) - probit estimation

\begin{tabular}{|c|c|c|c|c|c|}
\hline VARIABLES & $\begin{array}{l}\text { Healthcare } \\
\text { decisions }\end{array}$ & Social decisions & Consumption decisions & Financial decisions & All decisions \\
\hline \multicolumn{6}{|l|}{ Sons (ref: none) } \\
\hline At least one son & $0.127 * *(0.051)$ & $0.216 * * *(0.054)$ & $0.187 * * *(0.060)$ & $0.045(0.062)$ & $0.227 * * *(0.066)$ \\
\hline Age & $0.024 * * *(0.003)$ & $0.029 * * *(0.003)$ & $0.030 * * *(0.003)$ & $0.008 * * *(0.003)$ & $0.019 * * *(0.003)$ \\
\hline Age difference & $0.007 * *(0.004)$ & $0.010 * * *(0.003)$ & $0.008 * *(0.004)$ & $-0.001(0.004)$ & $0.003(0.005)$ \\
\hline \multicolumn{6}{|c|}{ Education (ref: none) } \\
\hline Primary & $0.067(0.050)$ & $0.142 * *(0.056)$ & $0.031(0.054)$ & $0.076(0.063)$ & $0.150 * *(0.069)$ \\
\hline Secondary & $0.213 * * *(0.071)$ & $0.159 * *(0.064)$ & $0.128 *(0.071)$ & $0.107(0.081)$ & $0.319 * * *(0.086)$ \\
\hline Higher & $0.429 * * *(0.099)$ & $0.353^{* * *}(0.100)$ & $0.314 * * *(0.098)$ & $0.214 * *(0.098)$ & $0.648 * * *(0.113)$ \\
\hline \multicolumn{6}{|c|}{ Spouse education (ref: none) } \\
\hline Primary & $-0.120 *(0.061)$ & $0.015(0.061)$ & $-0.037(0.064)$ & $-0.043(0.069)$ & $-0.015(0.067)$ \\
\hline Secondary & $-0.013(0.053)$ & $-0.004(0.054)$ & $-0.004(0.053)$ & $-0.037(0.057)$ & $-0.017(0.057)$ \\
\hline Higher & $0.011(0.063)$ & $0.030(0.066)$ & $0.031(0.075)$ & $-0.066(0.071)$ & $0.026(0.084)$ \\
\hline \multicolumn{6}{|c|}{ Employed (ref: none) } \\
\hline Yes & $0.176 * * *(0.053)$ & $0.194 * * *(0.045)$ & $0.235 * * *(0.052)$ & $0.146 * * *(0.056)$ & $0.219 * * *(0.055)$ \\
\hline \multicolumn{6}{|c|}{ Media exposure (ref: none) } \\
\hline occasionally & $0.148^{* *}(0.059)$ & $0.138 * *(0.059)$ & $0.143^{* *}(0.065)$ & $0.140 * *(0.063)$ & $0.253 * * *(0.063)$ \\
\hline Weekly & $0.000(0.114)$ & $0.048(0.113)$ & $0.176 *(0.106)$ & $0.003(0.144)$ & $0.213(0.131)$ \\
\hline Daily & $0.182 * * *(0.056)$ & $0.163^{* * *}(0.054)$ & $0.204^{* * *}(0.054)$ & $0.167 * * *(0.059)$ & $0.232 * * *(0.063)$ \\
\hline \multicolumn{6}{|c|}{ Family structure (ref: joint) } \\
\hline Nuclear family & $0.305^{* * *}(0.054)$ & $0.483 * * *(0.063)$ & $0.433 * * *(0.059)$ & $0.089(0.066)$ & $-0.092(0.073)$ \\
\hline Household size & $-0.035 * * *(0.007)$ & $-0.044 * * *(0.007)$ & $-0.052 * * *(0.008)$ & $-0.022 * * *(0.007)$ & $-0.039 * * *(0.008)$ \\
\hline \multicolumn{6}{|c|}{ Place of residence (ref: rural) } \\
\hline Urban & $0.209 * * *(0.062)$ & $0.160 * * *(0.054)$ & $0.165^{* * *}(0.051)$ & $0.135^{* *}(0.066)$ & $0.188 * *(0.073)$ \\
\hline \multicolumn{6}{|c|}{ Province/ Region (ref: Islamabad) } \\
\hline Punjab & $0.282 * * *(0.082)$ & $0.173 * * *(0.066)$ & $0.154 *(0.080)$ & $0.253^{* * *}(0.089)$ & $0.253 * * *(0.097)$ \\
\hline Sindh & $0.006(0.089)$ & $-0.159 * *(0.077)$ & $-0.324 * * *(0.087)$ & $-0.206 * *(0.096)$ & $-0.338 * * *(0.100)$ \\
\hline KPK & $-0.251 * * *(0.092)$ & $-0.362 * * *(0.081)$ & $-0.353 * * *(0.093)$ & $-0.272 * * *(0.100)$ & $-0.399 * * *(0.105)$ \\
\hline Gilgit-Baltistan & $-0.168(0.157)$ & $-0.119(0.163)$ & $-0.443 * * *(0.134)$ & $-0.744 * * *(0.135)$ & $-0.567 * * *(0.180)$ \\
\hline Balochistan & $-0.464 * * *(0.130)$ & $-0.554 * * *(0.125)$ & $-0.610 * * *(0.136)$ & $-0.655 * * *(0.135)$ & $-0.900 * * *(0.139)$ \\
\hline \multicolumn{6}{|c|}{ Have a car (ref: no) } \\
\hline Yes & $-0.091(0.085)$ & $0.029(0.073)$ & $-0.050(0.081)$ & $-0.050(0.074)$ & $-0.005(0.101)$ \\
\hline Marginal effect & $0.044 * *(0.017)$ & $0.073^{* * *}(0.018)$ & $0.062 * * *(0.020)$ & $0.016(0.022)$ & $0.065 * * *(0.020)$ \\
\hline Constant & $-1.145^{* * *}(0.141)$ & $-1.398 * * *(0.139)$ & $-1.304 * * *(0.150)$ & $-0.264 *(0.153)$ & $-0.130(0.162)$ \\
\hline Observations & 9,790 & 9,806 & 9,797 & 8,350 & 8,317 \\
\hline
\end{tabular}

Source: Authors' calculations.

Standard errors in parentheses

${ }^{* * *} \mathrm{p}<0.01,{ }^{* *} \mathrm{p}<0.05,{ }^{*} \mathrm{p}<0.1$ 
Table 24: Son preference and other measures of female empowerment (woman's BMI and labour force participation)

\begin{tabular}{|c|c|c|c|c|c|c|c|}
\hline \multirow[t]{2}{*}{ VARIABLES } & \multirow{2}{*}{$\begin{array}{l}\text { Body mass index } \\
\text { (BMI) }\end{array}$} & \multicolumn{4}{|c|}{ Ordered probit marginal effects for given bmi } & \multirow{2}{*}{$\begin{array}{l}\text { Women } \\
\text { employed }\end{array}$} & \multirow{2}{*}{$\begin{array}{l}\text { Probit marginal effect for } \\
\text { women employed }\end{array}$} \\
\hline & & Underweight $<\mathbf{1 8 . 5}$ & $\begin{array}{c}\text { Normal } \\
18.5- \\
24.9 \\
\end{array}$ & $\begin{array}{l}\text { Overweight } \\
25-29.9\end{array}$ & $\begin{array}{c}\begin{array}{c}\text { Obese } \\
30 \text { or } \\
\text { greater }\end{array} \\
\end{array}$ & & \\
\hline \multicolumn{8}{|c|}{ Sons (ref: none) } \\
\hline $\begin{array}{l}\text { At least one } \\
\text { son }\end{array}$ & & $-0.050 * * *$ & $\begin{array}{c}- \\
0.035^{* * *}\end{array}$ & $0.037^{* * *}$ & $0.048^{* * *}$ & $0.168^{* * *}$ & $0.053^{* * *}$ \\
\hline & $(0.058)$ & $(0.013)$ & $(0.008)$ & $(0.010)$ & $(0.011)$ & $(0.044)$ & $(0.013)$ \\
\hline Constant cut1 & $\begin{array}{c}-0.974 * * * \\
(0.058)\end{array}$ & & & & & & \\
\hline Constant cut2 & $\begin{array}{c}0.449 * * * \\
(0.053)\end{array}$ & & & & & & \\
\hline Constant cut3 & $\begin{array}{c}1.237 * * * \\
(0.057)\end{array}$ & & & & & & \\
\hline Constant & & & & & & $\begin{array}{c}-0.753^{* * * *} \\
((0.039)\end{array}$ & \\
\hline Observations & 3,920 & 3,920 & 3,920 & 3,920 & 3,920 & 11,487 & 11,487 \\
\hline
\end{tabular}

Source: Authors' calculations.

Standard errors in parentheses

$* * * \mathrm{p}<0.01,{ }^{* *} \mathrm{p}<0.05, * \mathrm{p}<0.1$ 
Table 25: Son Preference and consanguineous marriages - probit estimations

\begin{tabular}{|c|c|c|c|c|c|c|c|c|c|c|c|}
\hline \multirow[t]{2}{*}{ VARIABLES } & \multirow{2}{*}{$\begin{array}{l}\text { Consanguineous } \\
\text { marriage (cm) }\end{array}$} & \multicolumn{2}{|c|}{ Healthcare decisions-cm } & \multicolumn{2}{|c|}{ Social decisions-cm } & \multicolumn{2}{|c|}{ Consumption decisions-cm } & \multicolumn{2}{|c|}{ Financial decisions-cm } & \multicolumn{2}{|c|}{ All decisions-cm } \\
\hline & & Yes & No & Yes & No & Yes & No & Yes & No & Yes & No \\
\hline \multicolumn{12}{|c|}{ Sons (ref: none) } \\
\hline At least one son & $0.010(0.055)$ & $0.124 *(0.068)$ & $0.191 * *(0.082)$ & $0.222 * * *(0.070)$ & $0.197 * *(0.089)$ & $0.193 * *(0.077)$ & $0.134 *(0.084)$ & $0.074(0.083)$ & $-0.002(0.090)$ & $0.195 * *(0.097)$ & $0.285^{* *}(0.112)$ \\
\hline Age & $-0.000(0.003)$ & $0.024 * * *(0.003)$ & $0.025 * * *(0.004)$ & $0.030 * * *(0.004)$ & $0.028 * * *(0.005)$ & $0.030 * * *(0.004)$ & $0.030^{* * *}(0.005)$ & $0.005(0.004)$ & $0.008 *(0.005)$ & $0.019 * * *(0.004)$ & $0.015^{* * *}(0.005)$ \\
\hline Age difference & $-0.014 * * *(0.003)$ & $0.009 *(0.005)$ & $0.002(0.007)$ & $0.011 * *(0.005)$ & $0.009(0.006)$ & $0.011^{* *}(0.005)$ & $0.004(0.006)$ & $0.000(0.005)$ & $-0.006(0.006)$ & $0.001(0.006)$ & $0.001(0.007)$ \\
\hline \multicolumn{12}{|c|}{ Women education (ref: none) } \\
\hline Primary & $-0.045(0.060)$ & $0.083(0.069)$ & $0.014(0.098)$ & $0.185^{* *}(0.073)$ & $0.027(0.099)$ & $0.051(0.067)$ & $-0.030(0.098)$ & $0.121(0.085)$ & $-0.070(0.098)$ & $0.168 *(0.091)$ & $0.045(0.115)$ \\
\hline Secondary & $-0.225 * * *(0.060)$ & $0.245^{* *}(0.100)$ & $0.189 *(0.099)$ & $0.150 *(0.089)$ & $0.064(0.086)$ & $0.155 *(0.089)$ & $0.048(0.100)$ & $0.124(0.119)$ & $0.016(0.104)$ & $0.262 *(0.143)$ & $0.255^{* *}(0.105)$ \\
\hline Higher & $-0.566 * * *(0.078)$ & $0.513^{* * * *}(0.130)$ & $0.281 * *(0.130)$ & $0.360 * * *(0.126)$ & $0.284^{* *}(0.122)$ & $0.382 * * *(0.124)$ & $0.227 *(0.128)$ & $0.200(0.139)$ & $0.114(0.128)$ & $0.673^{* * *}(0.145)$ & $0.431^{* * *}(0.154)$ \\
\hline \multicolumn{12}{|c|}{ Spouse education (ref: none) } \\
\hline Primary & $0.130^{* *}(0.056)$ & $-0.212 * * *(0.075)$ & $0.021(0.095)$ & $-0.014(0.075)$ & $0.011(0.089)$ & $-0.078(0.080)$ & $-0.025(0.100)$ & $-0.141 *(0.085)$ & $0.054(0.096)$ & $-0.065(0.085)$ & $-0.019(0.092)$ \\
\hline Secondary & $0.217 * * *(0.053)$ & $-0.061(0.061)$ & $0.042(0.087)$ & $0.003(0.066)$ & $-0.037(0.085)$ & $-0.007(0.063)$ & $-0.043(0.087)$ & $-0.115 *(0.066)$ & $-0.043(0.091)$ & $-0.053(0.067)$ & $-0.043(0.096)$ \\
\hline Higher & $0.337 * * *(0.067)$ & $0.005(0.080)$ & $0.045(0.118)$ & $0.050(0.093)$ & $0.023(0.114)$ & $0.047(0.096)$ & $0.009(0.117)$ & $-0.071(0.092)$ & $-0.131(0.111)$ & $-0.015(0.107)$ & $0.027(0.133)$ \\
\hline \multicolumn{12}{|c|}{ Women employed (ref: none) } \\
\hline Yes & $0.114 * *(0.055)$ & $0.220 * * *(0.057)$ & $0.154 *(0.085)$ & $0.191 * * *(0.051)$ & $0.317 * * *(0.085)$ & $0.240 * * *(0.056)$ & $0.321 * * *(0.085)$ & $0.240 * * *(0.061)$ & $0.087(0.092)$ & $0.263 * * *(0.059)$ & $0.258 * *(0.102)$ \\
\hline \multicolumn{12}{|c|}{ Media exposure (ref: none) } \\
\hline Occasionally & $-0.051(0.053)$ & $0.043(0.070)$ & $0.287 * * *(0.094)$ & $0.004(0.074)$ & $0.309 * * *(0.097)$ & $0.010(0.086)$ & $0.352 * * *(0.095)$ & $0.033(0.078)$ & $0.216^{* *}(0.092)$ & $0.140 *(0.078)$ & $0.377 * * *(0.109)$ \\
\hline Weekly & $0.118(0.128)$ & $-0.053(0.142)$ & $-0.004(0.217)$ & $-0.118(0.138)$ & $0.330 *(0.200)$ & $0.088(0.127)$ & $0.247(0.207)$ & $-0.039(0.166)$ & $-0.144(0.245)$ & $0.101(0.158)$ & $0.236(0.238)$ \\
\hline Daily & $0.005(0.053)$ & $0.094(0.066)$ & $0.255^{* * *}(0.090)$ & $0.101(0.065)$ & $0.198 * *(0.089)$ & $0.131 * *(0.065)$ & $0.257^{* * *}(0.092)$ & $0.080(0.073)$ & $0.152 *(0.088)$ & $0.143 *(0.082)$ & $0.265^{* *}(0.109)$ \\
\hline \multicolumn{12}{|c|}{ Family structure (ref: joint) } \\
\hline Nuclear family & $-0.095 *(0.049)$ & $0.265 * * *(0.066)$ & $0.331 * * *(0.092)$ & $0.422 * * *(0.075)$ & $0.464 * * *(0.099)$ & $0.369 * * *(0.072)$ & $0.418 * * *(0.096)$ & $0.027(0.082)$ & $0.170 *(0.101)$ & $-0.107(0.089)$ & $-0.004(0.117)$ \\
\hline Household size & $0.019 * * *(0.005)$ & $-0.029 * * *(0.008)$ & $-0.032 * * *(0.010)$ & $-0.043 * * *(0.008)$ & $-0.029 * * *(0.010)$ & $-0.050 * * *(0.008)$ & $-0.039 * * *(0.011)$ & $-0.023^{* * *}(0.008)$ & $-0.011(0.010)$ & $-0.034 * * *(0.008)$ & $-0.038^{* * * *}(0.012)$ \\
\hline \multicolumn{12}{|c|}{ Province/ Region (ref: Islamabad) } \\
\hline Punjab & $0.016(0.085)$ & $0.291^{* * *}(0.105)$ & $0.288 * *(0.112)$ & $0.159 *(0.085)$ & $0.178 *(0.101)$ & $0.210 * *(0.092)$ & $0.104(0.112)$ & $0.270 * *(0.110)$ & $0.217 *(0.112)$ & $0.285 * *(0.125)$ & $0.211 *(0.122)$ \\
\hline Sindh & $0.049(0.092)$ & $-0.013(0.116)$ & $0.152(0.110)$ & $-0.204 * *(0.097)$ & $-0.005(0.105)$ & $-0.318^{* * * *}(0.101)$ & $-0.175(0.114)$ & $-0.212 *(0.121)$ & $-0.049(0.116)$ & $-0.327 * * *(0.126)$ & $-0.152(0.123)$ \\
\hline KPK region & $-0.302 * * *(0.094)$ & $-0.279 * *(0.115)$ & $-0.230 *(0.121)$ & $-0.357 * * *(0.104)$ & $-0.444 * * *(0.121)$ & $-0.321 * * *(0.113)$ & $-0.408^{* * *}(0.123)$ & $-0.332 * * *(0.122)$ & $-0.236 *(0.129)$ & $-0.337 * *(0.133)$ & $-0.436 * * *(0.131)$ \\
\hline Gilgit-Baltistan & $-0.685 * * *(0.153)$ & $-0.347(0.216)$ & $0.026(0.167)$ & $-0.302(0.216)$ & $0.024(0.166)$ & $-0.515 * * *(0.190)$ & $-0.363 * *(0.150)$ & $-0.801 * * *(0.187)$ & $-0.638 * * *(0.151)$ & $-0.682 * * *(0.240)$ & $-0.248(0.171)$ \\
\hline Balochistan & $-0.159(0.113)$ & $-0.503^{* * * *}(0.145)$ & $-0.374 * *(0.168)$ & $-0.567 * * *(0.143)$ & $-0.562 * * *(0.149)$ & $-0.552 * * *(0.147)$ & $-0.656 * * *(0.168)$ & $-0.642 * * *(0.155)$ & $-0.593 * * *(0.158)$ & $-0.907 * * *(0.160)$ & $-0.737 * * *(0.168)$ \\
\hline \multicolumn{12}{|c|}{ Economic status (ref: poorest) } \\
\hline Poorer & $-0.145(0.091)$ & $0.182 * *(0.073)$ & $0.306 * *(0.118)$ & $0.239 * * *(0.080)$ & $0.109(0.119)$ & $0.217 * * *(0.076)$ & $0.225 *(0.115)$ & $0.324 * * *(0.070)$ & $0.276^{* *}(0.124)$ & $0.138(0.104)$ & $0.254 * *(0.128)$ \\
\hline Middle & $-0.355^{* * *}(0.099)$ & $.126(0.100)$ & $0.136(0.136)$ & $0.075(0.081)$ & $0.191(0.135)$ & $0.104(0.084)$ & $0.219 *(0.127)$ & $0.378 * * *(0.097)$ & $0.225(0.144)$ & $0.201^{* *}(0.094)$ & $0.303 *(0.161)$ \\
\hline Rich & $-0.531 * * *(0.110)$ & $0.011(0.107)$ & $0.293^{* *}(0.147)$ & $0.046(0.091)$ & $0.187(0.142)$ & $0.063(0.096)$ & $0.229 *(0.134)$ & $0.209 *(0.115)$ & $0.261 *(0.152)$ & $0.042(0.111)$ & $0.453^{* * *}(0.167)$ \\
\hline Richest & $-0.434 * * *(0.119)$ & $0.004(0.133)$ & $0.204(0.179)$ & $0.138(0.123)$ & $0.117(0.164)$ & $0.152(0.117)$ & $0.061(0.155)$ & $0.258(0.161)$ & $0.278(0.170)$ & $0.194(0.153)$ & $0.411 * *(0.201)$ \\
\hline Marginal effect & $0.003(0.019)$ & $0.043 *(0.024)$ & $0.065^{* *}(0.028)$ & $0.075^{* * * *}(0.023)$ & $0.065^{* *}(0.029)$ & $0.064 * *(0.025)$ & $0.045^{*}(0.028)$ & $0.026(0.030)$ & $-0.000(0.033)$ & $0.058^{* *}(0.029)$ & $0.076 * *(0.032)$ \\
\hline Constant & $0.723 * * *(0.148)$ & $-1.190 * * *(0.175)$ & $-1.485^{* * *}(0.225)$ & $-1.436 * * *(0.161)$ & $-1.508^{* * *}(0.221)$ & $-1.381^{* * *}(0.171)$ & $-1.476^{* * *}(0.235)$ & $-0.309(0.190)$ & $-0.482^{* *}(0.231)$ & $-0.179(0.191)$ & $-0.319(0.246)$ \\
\hline Observations & 10,049 & 6,170 & 3,844 & 6,174 & 3,858 & 6,169 & 3,854 & 5,181 & 3,348 & 5,165 & 3,329 \\
\hline
\end{tabular}

Standard errors i palculations.

Standard errors in parentheses
${ }_{* * *} \mathrm{p}<0.01,{ }^{* *} \mathrm{p}<0.05,{ }^{*} \mathrm{p}<0.1$ 
Table 26: Son Preference, spouse's employment status and number of visits by the survey team - probit estimations

\begin{tabular}{|c|c|c|}
\hline VARIABLES & Husband works & $\begin{array}{c}\text { survey team visited once or } \\
\text { more }\end{array}$ \\
\hline \multicolumn{3}{|l|}{ Sons (ref: none) } \\
\hline At least one son & $0.128(0.102)$ & $0.098(0.112)$ \\
\hline Age & $-0.029 * * *(0.005)$ & $0.004(0.007)$ \\
\hline Age difference & $-0.024 * * *(0.007)$ & $-0.002(0.007)$ \\
\hline \multicolumn{3}{|c|}{ Women education (ref: none) } \\
\hline Primary & $0.088(0.116)$ & $-0.199(0.124)$ \\
\hline Secondary & $-0.064(0.111)$ & $-0.120(0.125)$ \\
\hline Higher & $0.189(0.167)$ & $0.022(0.157)$ \\
\hline \multicolumn{3}{|c|}{ Spouse education (ref: none) } \\
\hline Primary & $0.059(0.135)$ & $0.054(0.119)$ \\
\hline Secondary & $-0.077(0.093)$ & $0.057(0.108)$ \\
\hline Higher & $-0.106(0.122)$ & $-0.051(0.132)$ \\
\hline \multicolumn{3}{|c|}{ Women employed (ref: none) } \\
\hline Yes & $-0.096(0.096)$ & $0.457 * * *(0.082)$ \\
\hline \multicolumn{3}{|c|}{ Media exposure (ref: none) } \\
\hline Occasionally & $0.315 * * *(0.101)$ & $0.031(0.135)$ \\
\hline Weekly & $0.145(0.214)$ & $-0.336(0.228)$ \\
\hline Daily & $0.108(0.089)$ & $-0.028(0.134)$ \\
\hline \multicolumn{3}{|c|}{ Family structure (ref: joint) } \\
\hline Nuclear family & $0.161(0.099)$ & $0.090(0.142)$ \\
\hline Household size & $0.016 *(0.009)$ & $0.020 *(0.011)$ \\
\hline \multicolumn{3}{|c|}{ Place of residence (ref: rural) } \\
\hline Urban & $0.171 *(0.102)$ & $0.106(0.110)$ \\
\hline \multicolumn{3}{|c|}{ Province/ Region (ref: Islamabad) } \\
\hline Punjab & $-0.224(0.164)$ & $-0.568 * * *(0.120)$ \\
\hline Sindh & $0.034(0.171)$ & $-0.666 * * *(0.130)$ \\
\hline KPK region & $-0.650 * * *(0.174)$ & $-0.438 * * *(0.141)$ \\
\hline Gilgit-Baltistan & $-0.970 * * *(0.187)$ & $-0.434 * *(0.216)$ \\
\hline Balochistan & $-0.672 * * *(0.181)$ & $-1.017 * * *(0.205)$ \\
\hline \multicolumn{3}{|c|}{ Economic status (ref: poorest) } \\
\hline Poorer & $0.011(0.090)$ & $0.295(0.239)$ \\
\hline Middle & $-0.066(0.108)$ & $0.359 *(0.214)$ \\
\hline Rich & $-0.028(0.136)$ & $0.208(0.238)$ \\
\hline Richest & $0.003(0.172)$ & $0.487 *(0.261)$ \\
\hline Marginal effect & $0.008(0.007)$ & $0.005(0.005)$ \\
\hline Constant & $2.924 * * *(0.258)$ & $-2.298 * * *(0.211)$ \\
\hline Observations & 10,052 & 10,052 \\
\hline
\end{tabular}

Source: Authors' calculations.

Standard errors in parentheses

${ }^{* * *} \mathrm{p}<0.01,{ }^{* *} \mathrm{p}<0.05,{ }^{*} \mathrm{p}<0.1$ 
Table 27: Multivariate analysis of variance and covariance

\begin{tabular}{|c|c|c|c|c|c|c|c|}
\hline Source & \multicolumn{2}{|c|}{ Statistic } & \multirow{2}{*}{$\frac{\text { df }}{1}$} & \multirow{2}{*}{ F(df1, } & \multirow{2}{*}{$\begin{array}{r}\text { df2) } \\
8549\end{array}$} & \multirow{2}{*}{\begin{tabular}{|c|}
$\mathbf{F}$ \\
3.11
\end{tabular}} & \multirow{2}{*}{$\begin{array}{l}\text { Prob }>\mathbf{F} \\
0.0083\end{array}$} \\
\hline At least one & $\mathrm{W}$ & 0.998 & & & & & \\
\hline \multirow[t]{3}{*}{ son } & $\mathrm{P}$ & 0.001 & & 5.0 & 8549 & 3.11 & 0.0083 e \\
\hline & $\mathrm{L}$ & 0.001 & & 5.0 & 8549 & 3.11 & 0.0083 e \\
\hline & $\mathrm{R}$ & 0.001 & & 5.0 & 8549 & 3.11 & 0.0083 e \\
\hline Residual & & 3553 & & & & & \\
\hline Total & & 3554 & & & & & \\
\hline
\end{tabular}


Table 28: Bonferroni correction

\begin{tabular}{lcccc}
\hline Equations & Contrast & Std.Err. & \multicolumn{2}{c}{ Bonferroni } \\
& & & $\mathbf{t}$ & $\mathbf{P}>|\mathbf{t}|$ \\
\hline 2 vs 1 & 0.007 & 0.007 & 1.12 & 1.000 \\
3 vs 1 & -0.031 & 0.006 & -4.58 & 0.000 \\
4 vs 1 & -0.046 & 0.007 & -6.30 & 0.000 \\
5 vs 1 & 0.130 & 0.005 & 22.78 & 0.000 \\
3 vs 2 & -0.039 & 0.006 & -6.31 & 0.000 \\
4 vs 2 & -0.053 & 0.007 & -7.10 & 0.000 \\
5 vs 2 & 0.123 & 0.005 & 22.51 & 0.000 \\
4 vs 3 & -0.014 & 0.007 & -2.05 & 0.406 \\
5 vs 3 & 0.162 & 0.006 & 26.13 & 0.000 \\
5 vs 4 & 0.176 & 0.006 & 26.68 & 0.000 \\
\hline
\end{tabular}

Source: Authors' calculations.

10 number of comparisons 


\section{Appendix}

Table A1: Son preference and female participation in decisionmaking (parity 4) - probit estimation

\begin{tabular}{|c|c|c|}
\hline VARIABLES & $\begin{array}{l}\text { All decisions } \\
\text { (Parity } \leq 4)\end{array}$ & $\begin{array}{c}\text { All decisions } \\
\text { (Parity }>4)\end{array}$ \\
\hline \multicolumn{3}{|l|}{ Sons (ref: none) } \\
\hline At least one son & $0.214^{* * *}(0.072)$ & $0.599(0.379)$ \\
\hline Age & $0.018 * * *(0.004)$ & $0.019 * *(0.007)$ \\
\hline Age difference & $0.002(0.006)$ & $0.003(0.007)$ \\
\hline \multicolumn{3}{|c|}{ Women education (ref: none) } \\
\hline Primary & $0.040(0.092)$ & $0.316^{* * *}(0.113)$ \\
\hline Secondary & $0.268 * *(0.106)$ & $0.263 *(0.143)$ \\
\hline Higher & $0.583 * * *(0.123)$ & $0.315(0.262)$ \\
\hline \multicolumn{3}{|c|}{ Spouse education (ref: none) } \\
\hline Primary & $0.031(0.088)$ & $-0.144(0.097)$ \\
\hline Secondary & $-0.007(0.067)$ & $-0.114(0.101)$ \\
\hline Higher & $0.043(0.099)$ & $-0.123(0.147)$ \\
\hline \multicolumn{3}{|c|}{ Women employed (ref: none) } \\
\hline Yes & $0.260 * * *(0.070)$ & $0.269 * * *(0.079)$ \\
\hline \multicolumn{3}{|c|}{ Media exposure (ref: none) } \\
\hline Occasionally & $0.313^{* * *}(0.090)$ & $0.085(0.104)$ \\
\hline Weekly & $0.170(0.162)$ & $0.146(0.267)$ \\
\hline Daily & $0.215^{* *}(0.084)$ & $0.162(0.102)$ \\
\hline \multicolumn{3}{|c|}{ Family structure (ref: joint) } \\
\hline Nuclear family & $-0.017(0.086)$ & $-0.188(0.154)$ \\
\hline Household size & $-0.031^{* * *}(0.009)$ & $-0.039 * * *(0.013)$ \\
\hline \multicolumn{3}{|c|}{ Place of residence (ref: rural) } \\
\hline Urban & $0.213^{* *}(0.092)$ & $0.027(0.110)$ \\
\hline \multicolumn{3}{|c|}{ Province/ Region (ref: Islamabad) } \\
\hline Punjab & $0.257 * * *(0.097)$ & $0.260(0.176)$ \\
\hline Sindh & $-0.235 * *(0.097)$ & $-0.374 * *(0.180)$ \\
\hline KPK region & $-0.473 * * *(0.105)$ & $-0.291(0.185)$ \\
\hline Gilgit-Baltistan & $-0.394 * *(0.182)$ & $-0.583 * *(0.241)$ \\
\hline Balochistan & $-0.780 * * *(0.152)$ & $-0.968 * * *(0.198)$ \\
\hline \multicolumn{3}{|c|}{ Economic status (ref: poorest) } \\
\hline Poorer & $0.116(0.104)$ & $0.225^{* *}(0.109)$ \\
\hline Middle & $0.150(0.105)$ & $0.333 * * *(0.119)$ \\
\hline Rich & $0.090(0.125)$ & $0.342 * *(0.142)$ \\
\hline Richest & $0.158(0.128)$ & $0.371 *(0.194)$ \\
\hline Marginal effect & $0.059 * * *(0.020)$ & $0.193(0.132)$ \\
\hline Constant & $-0.298(0.189)$ & $-0.475(0.528)$ \\
\hline Observations & 5,232 & 3,265 \\
\hline
\end{tabular}


Table A2: Son preference and female participation in decisionmaking (with age square interaction effect) - probit estimation

\begin{tabular}{|c|c|c|c|c|}
\hline & Healthcare decisions & Social decisions & Consumption decisions & Financial decisions \\
\hline \multicolumn{5}{|l|}{ Sons (ref: none) } \\
\hline $\begin{array}{l}\text { Age } \\
\text { Age Square } \\
\text { Age difference } \\
\text { Women educatio }\end{array}$ & $\begin{array}{l}0.0435 * *(0.0193) \\
-0.000288(0.000280) \\
0.00777 * *(0.00360) \\
\text { e) }\end{array}$ & $\begin{array}{l}0.0477 * *(0.0200) \\
-0.000277(0.000292) \\
0.0113^{* * *}(0.00326)\end{array}$ & $\begin{array}{l}0.0665 * * *(0.0210) \\
-0.000540 *(0.000309) \\
0.00908^{* *}(0.00366)\end{array}$ & $\begin{array}{l}0.000957(0.0222) \\
7.06 \mathrm{e}-05(0.000317) \\
-0.00167(0.00375)\end{array}$ \\
\hline $\begin{array}{l}\text { Primary } \\
\text { Secondary } \\
\text { Higher }\end{array}$ & $\begin{array}{l}0.0598(0.0507) \\
0.238^{* * *}(0.0733) \\
0.424^{* * *}(0.0957)\end{array}$ & $\begin{array}{l}0.138^{* *}(0.0573) \\
0.130 *(0.0669) \\
0.342^{* * *}(0.0987)\end{array}$ & $\begin{array}{l}0.0294(0.0548) \\
0.117^{*}(0.0705) \\
0.303^{* * *}(0.0942)\end{array}$ & $\begin{array}{l}0.0536(0.0686) \\
0.0894(0.0876) \\
0.159(0.107)\end{array}$ \\
\hline \multicolumn{5}{|c|}{ Spouse education (ref: none) } \\
\hline Primary & $-0.139 * *(0.0608)$ & $-0.00617(0.0594)$ & $-0.0618(0.0638)$ & $-0.0773(0.0681)$ \\
\hline Secondary & $-0.0299(0.0545)$ & $-0.0232(0.0568)$ & $-0.0284(0.0553)$ & $-0.0841(0.0573)$ \\
\hline Higher & $0.00516(0.0682)$ & $0.0247(0.0724)$ & $0.0209(0.0783)$ & $-0.0999(0.0719)$ \\
\hline \multicolumn{5}{|c|}{ Women employed (ref: none) } \\
\hline \multicolumn{4}{|c|}{ Media exposure (ref: none) } & $0.185^{* * *}(0.0549)$ \\
\hline $\begin{array}{l}\text { Occasionally } \\
\text { Weekly } \\
\text { Daily }\end{array}$ & $\begin{array}{l}0.118 *(0.0606) \\
-0.0429(0.113) \\
0.140^{* *}(0.0560)\end{array}$ & $\begin{array}{l}0.0991 *(0.0601) \\
-0.00509(0.119) \\
0.120 * *(0.0547)\end{array}$ & $\begin{array}{l}0.117 *(0.0691) \\
0.124(0.107) \\
0.159 * * *(0.0552)\end{array}$ & $\begin{array}{l}0.0888(0.0627) \\
-0.0696(0.141) \\
0.0998 *(0.0577)\end{array}$ \\
\hline \multicolumn{5}{|c|}{ Family structure (ref: joint) } \\
\hline $\begin{array}{l}\text { Nuclear family } \\
\text { Household size }\end{array}$ & $\begin{array}{l}0.285^{* * *}(0.0539) \\
-0.0305 * * *(0.00629)\end{array}$ & $\begin{array}{l}0.439 * * *(0.0620) \\
-0.0395 * * *(0.00684)\end{array}$ & $\begin{array}{l}0.382^{* * *}(0.0575) \\
-0.0474 * * *(0.00664)\end{array}$ & $\begin{array}{l}0.0831(0.0650) \\
-0.0184 * * *(0.00623)\end{array}$ \\
\hline \multicolumn{5}{|c|}{$\begin{array}{l}\text { Place of residence (ref: rural) } \\
\text { Plo }\end{array}$} \\
\hline \multirow{2}{*}{\multicolumn{5}{|c|}{ Province/ Region (ref: Islamabad) }} \\
\hline & & & & \\
\hline Punjab & $0.299 * * *(0.0793)$ & $0.173^{* * *}(0.0618)$ & $0.175^{* *}(0.0750)$ & $0.257^{* * *}(0.0862)$ \\
\hline Sindh & $0.0439(0.0884)$ & $-0.138 *(0.0731)$ & $-0.274^{* * *}(0.0838)$ & $-0.152(0.0960)$ \\
\hline KPK & $-0.257^{* * *}(0.0917)$ & $-0.383^{* * *}(0.0788)$ & $-0.350^{* * *}(0.0908)$ & $-0.283^{* * *}(0.0996)$ \\
\hline Gilgit-Baltistan & $-0.150(0.160)$ & $-0.113(0.163)$ & $-0.418^{* * *}(0.132)$ & $-0.694^{* * *}(0.138)$ \\
\hline \multicolumn{5}{|c|}{ Economic status (ref: poorest) } \\
\hline Poorer & $0.211^{* * *}(0.0631)$ & $0.216^{* * *}(0.0654)$ & $0.225^{* * *}(0.0641)$ & $0.313^{* * *}(0.0637)$ \\
\hline Middle & $0.121(0.0813)$ & $0.141 *(0.0717)$ & $0.158^{* *}(0.0709)$ & $0.327^{* * *}(0.0830)$ \\
\hline Rich & $0.117(0.0901)$ & $0.141 *(0.0765)$ & $0.151 *(0.0788)$ & $0.237 * *(0.0934)$ \\
\hline Richest & $0.0683(0.109)$ & $0.158(0.0975)$ & $0.126(0.0963)$ & $0.269^{* *}(0.120)$ \\
\hline $\begin{array}{l}\text { Constant } \\
\text { Observations }\end{array}$ & $-1.591^{* * *}(0.326){ }_{10,017}$ & $\begin{array}{r}-1.758^{* * *}(0.343) \\
10,035\end{array}$ & $-1.980^{* * *(0.364)} 10,026$ & $-0.296(0.380)$ \\
\hline
\end{tabular}

Source: Authors' calculations.

Standard errors in parentheses

$* * * \mathrm{p}<0.01, * * \mathrm{p}<0.05, * \mathrm{p}<0.1$ 